\title{
SOLID WASTE FROM THE OPERATION AND DECOMMISSIONING OF POWER PLANTS
}

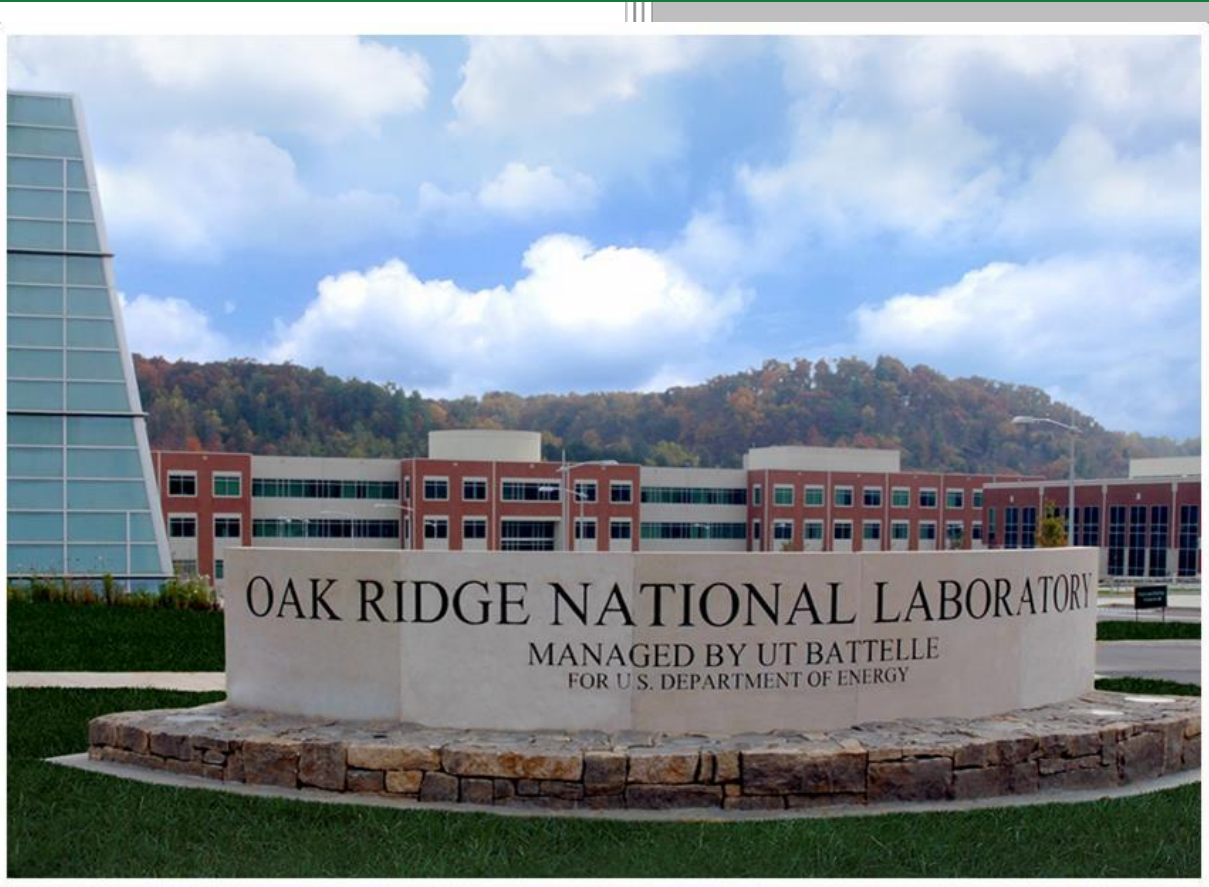

Approved for public release.

Marilyn A. Brown

Daniel D'Arcy

Melissa Lapsa

Isha Sharma

Yufei Li

Distribution is unlimited.

January 5, 2017 


\section{DOCUMENT AVAILABILITY}

Reports produced after January 1, 1996, are generally available free via US Department of Energy (DOE) SciTech Connect.

\section{Website http://www.osti.gov/scitech/}

Reports produced before January 1,1996, may be purchased by members of the public from the following source:

National Technical Information Service

5285 Port Royal Road

Springfield, VA 22161

Telephone 703-605-6000 (1-800-553-6847)

TDD 703-487-4639

Fax 703-605-6900

E-mail info@ntis.gov

Website http://www.ntis.gov/help/ordermethods.aspx

Reports are available to DOE employees, DOE contractors, Energy Technology Data Exchange representatives, and International Nuclear Information System representatives from the following source:

Office of Scientific and Technical Information

PO Box 62

Oak Ridge, TN 37831

Telephone 865-576-8401

Fax 865-576-5728

E-mail reports@osti.gov

Website http://www.osti.gov/contact.html

This report was prepared as an account of work sponsored by an agency of the United States Government. Neither the United States Government nor any agency thereof, nor any of their employees, makes any warranty, express or implied, or assumes any legal liability or responsibility for the accuracy, completeness, or usefulness of any information, apparatus, product, or process disclosed, or represents that its use would not infringe privately owned rights. Reference herein to any specific commercial product, process, or service by trade name, trademark, manufacturer, or otherwise, does not necessarily constitute or imply its endorsement, recommendation, or favoring by the United States Government or any agency thereof. The views and opinions of authors expressed herein do not necessarily state or reflect those of the United States Government or any agency thereof. 


\section{DOCUMENT AVAILABILITY}

Reports produced after January 1, 1996, are generally available free via US Department of Energy (DOE) SciTech Connect.

\section{Website http://www.osti.gov/scitech/}

Reports produced before January 1,1996, may be purchased by members of the public from the following source:

National Technical Information Service

5285 Port Royal Road

Springfield, VA 22161

Telephone 703-605-6000 (1-800-553-6847)

TDD 703-487-4639

Fax 703-605-6900

E-mail info@ntis.gov

Website http://www.ntis.gov/help/ordermethods.aspx

Reports are available to DOE employees, DOE contractors, Energy Technology Data Exchange representatives, and International Nuclear Information System representatives from the following source:

Office of Scientific and Technical Information

PO Box 62

Oak Ridge, TN 37831

Telephone 865-576-8401

Fax 865-576-5728

E-mail reports@osti.gov

Website http://www.osti.gov/contact.html

This report was prepared as an account of work sponsored by an agency of the United States Government. Neither the United States Government nor any agency thereof, nor any of their employees, makes any warranty, express or implied, or assumes any legal liability or responsibility for the accuracy, completeness, or usefulness of any information, apparatus, product, or process disclosed, or represents that its use would not infringe privately owned rights. Reference herein to any specific commercial product, process, or service by trade name, trademark, manufacturer, or otherwise, does not necessarily constitute or imply its endorsement, recommendation, or favoring by the United States Government or any agency thereof. The views and opinions of authors expressed herein do not necessarily state or reflect those of the United States Government or any agency thereof. 
Energy and Transportation Science Division

\title{
SOLID WASTE FROM THE OPERATION AND DECOMMISSIONING OF POWER PLANTS
}

\author{
Marilyn A. Brown, Georgia Institute of Technology \\ Daniel D'Arcy, Georgia Institute of Technology \\ Melissa Lapsa, Oak Ridge National Laboratory \\ Isha Sharma, Oak Ridge National Laboratory \\ Yufei Li, Georgia Institute of Technology
}

January 5, 2017

Prepared by

OAK RIDGE NATIONAL LABORATORY

Oak Ridge, TN 37831-6283

managed by

UT-BATTELLE, LLC

for the

US DEPARTMENT OF ENERGY

under contract DE-AC05-00OR22725 
Oak Ridge National Laboratory prepared this report for DOE EPSA as part of a series of "baseline" reports intended to inform the second installment of the Quadrennial Energy Review (QER 1.2). QER 1.2 will provide a comprehensive review of the nation's electricity system and covers the current state and key trends related to the electricity system, including generation, transmission, distribution, grid operations and planning, and end use. The baseline reports provide an overview of electricity system elements.

To help understand how the energy systems might develop into the future under Business as Usual (BAU) conditions QER 1.1 relied upon the U.S. Energy Information's Annual Energy Outlook (AEO) 2014 Reference Case. EPSA could not rely completely upon AEO for QER 1.2 as AEO 2016 was not completed and AEO 2015 did not include the Clean Power Plan. So the EPSA Base Case was developed and it aligns as closely as possible with AEO 2016 given the timing issues.

The EPSA Base Case scenario was constructed using EPSA-NEMS, ${ }^{1}$ a version of the same integrated energy system model used by EIA. The EPSA Base Case input assumptions were based mainly on the final release of AEO 2015, with a few exceptions as noted below, and then updated to include the Clean Power Plan and tax extenders. As with the AEO, the ESPA Base Case provides one possible scenario of base case energy sector demand, generation, and emissions from present day to 2040, and it does not include future policies that might be passed or future technological progress.

The EPSA Base Case input assumptions were based mainly on the final release of the AEO 2015, with a few updates that reflect current technology cost and performance estimates, policies, and measures. Assumptions from the EIA 2015 High Oil and Gas Resources Case were used; it has lower gas prices similar to those in AEO 2016. The EPSA Base Case achieves the broad emission reductions required by the Clean Power Plan. While states will ultimately decide how to comply with the Clean Power Plan, the EPSA Base Case assumes that states choose the mass-based state goal approach with new source complement and assumes national emission trading among the states, but does not model the Clean Energy Incentive Program because it is not yet finalized. The EPSA Base Case also includes the tax credit extensions for solar and wind passed in December 2015. In addition, the utility-scale solar and wind renewable cost and performance estimates have been updated to be consistent with EIA's AEO 2016. Carbon capture and storage (CCS) cost and performance estimates have also been updated to be consistent with the latest published information from the National Energy Technologies Laboratory. An EPSA Side Case was also completed, which has higher gas prices similar to those in the AEO 2015 Reference Case.

\footnotetext{
1 The version of the National Energy Modeling System (NEMS) used for the QER base case has been run by OnLocation, Inc., with input assumptions by EPSA. It uses a version of NEMS that differs from the one used by the U.S. Energy Information Administration (EIA), the model is referred to as EPSA-NEMS.
} 


\section{CONTENTS}

CONTENTS.

EXECUTIVE SUMMARY

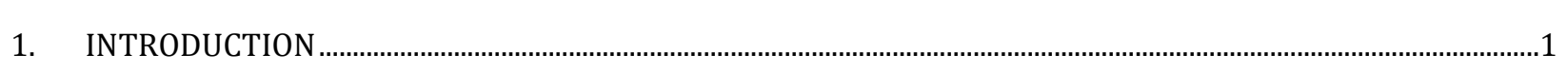

1.1 TRENDS IN THE U.S. ELECTRCITY GENERATION PORTFOLIO_..................................................................1

1.2 DRIVERS OF POWER PLANT RETIREMENTS...........................................................................................

1.3 RECENT AND PLANNED POWER PLANT RETIREMENTS ..........................................................................

1.4 OVERVIEW OF SOLID WASTE STREAMS FROM SIX SOURCES OF ELECTRICITY ......................................

2. COAL

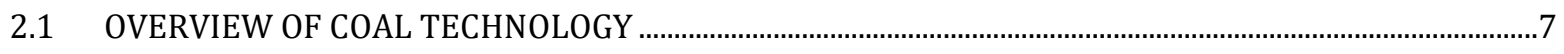

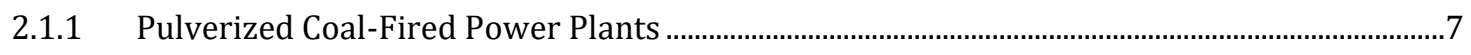

2.1.2 Fluidized-Bed Coal Plants ......................................................................................................

2.1.3 Integrated Gasification Combined Cycle (IGCC) Plants ................................................................

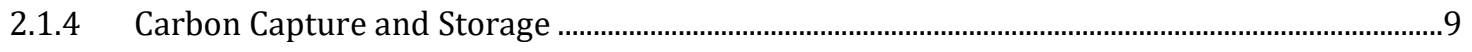

2.1.5 Other Coal Technologies ....................................................................................................... 10

2.2 WASTE GENERATION AND MANAGEMENT ……................................................................................ 10

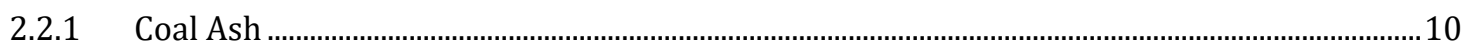

2.2.1.1 Coal Ash Storage and Management........................................................................13

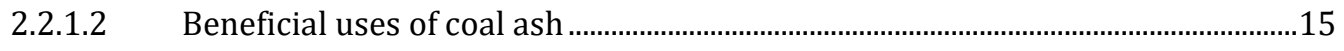

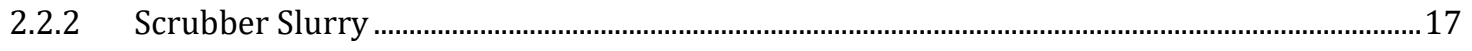

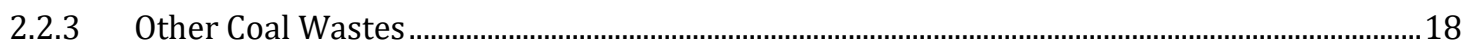

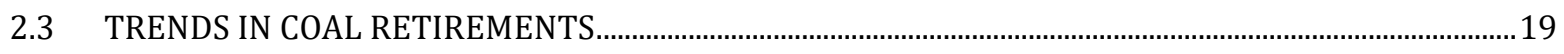

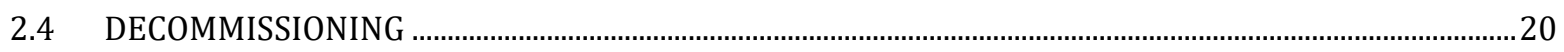

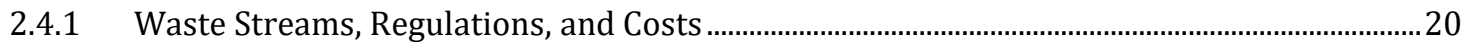

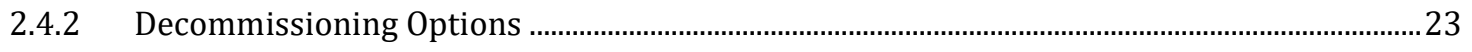

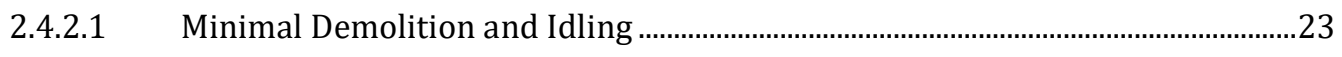

2.4.2.2 Full Decommissioning ......................................................................................23

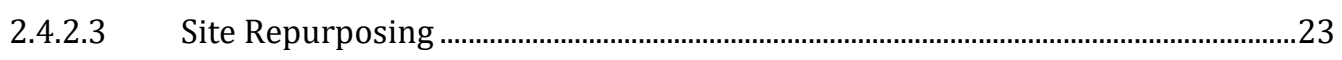




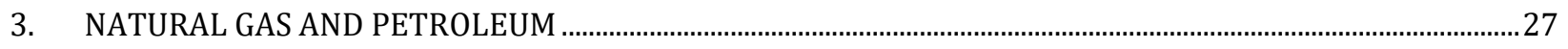

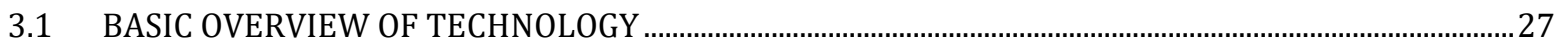

3.1.1 Natural Gas Combustion Turbines …………................................................................................

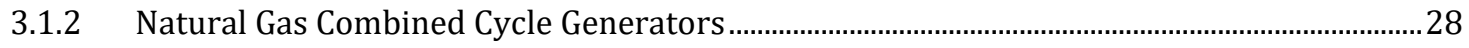

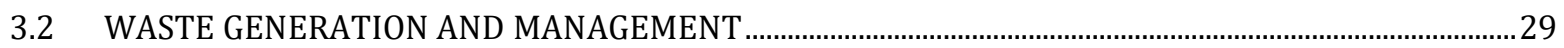

3.3 OPTIONS FOR DECOMMISSIONING OF GAS AND PETROLEUM POWER PLANTS...................................30

3.5 DECOMMISSIONING: WASTE STREAMS, REGULATIONS, AND COSTS..................................................... 31

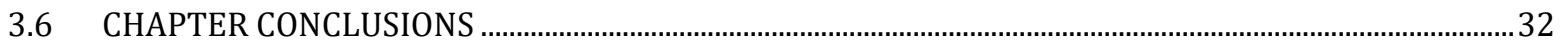

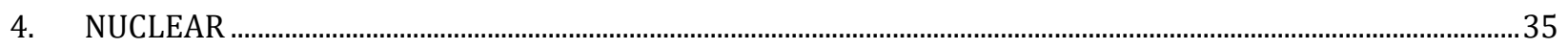

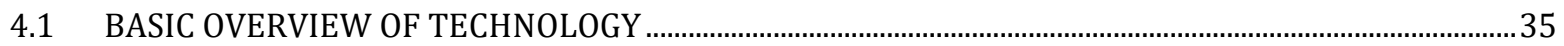

4.2 WASTE FROM GENERATION AND ITS MANAGEMENT …………….............................................................35

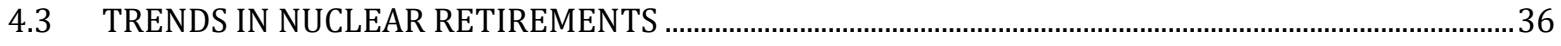

4.4 DECOMMISSIONING: WASTE STREAMS, REGULATIONS, AND COSTS .................................................... 37

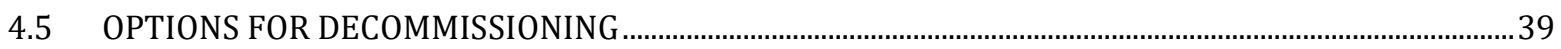

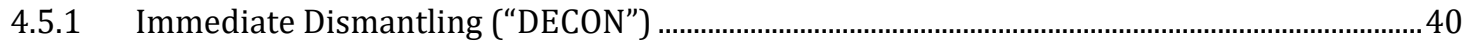

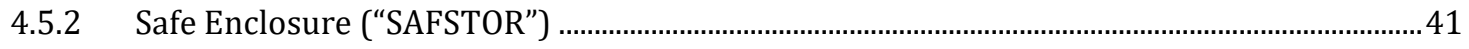

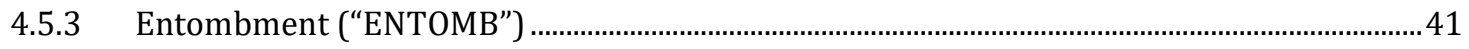

4.5.4 Discussion of Options for Decommissioning ............................................................................... 41

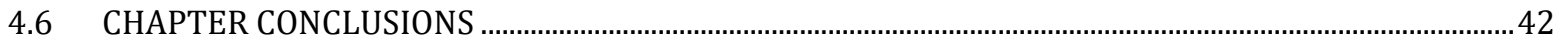

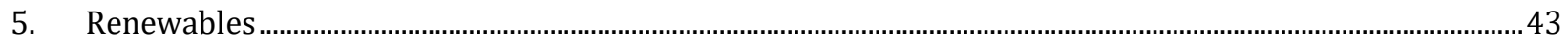

5.1 BASIC OVERVIEW OF RENEWABLE ENERGY ........................................................................................... 43

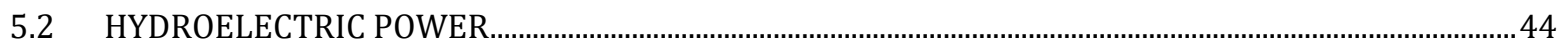

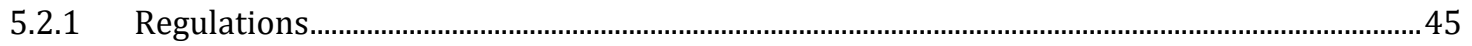

5.2.3 Issues Related to Dam Removal................................................................................................... 48

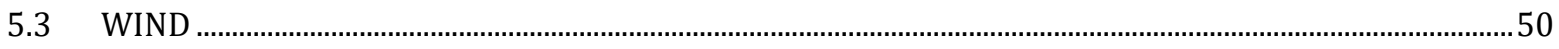

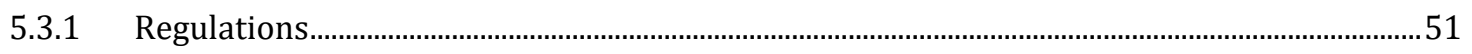

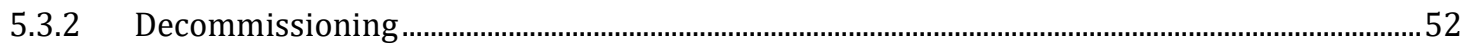


5.4 SOLAR

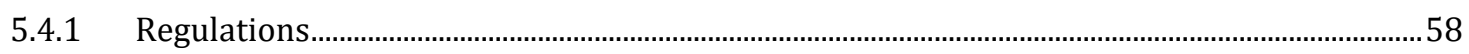

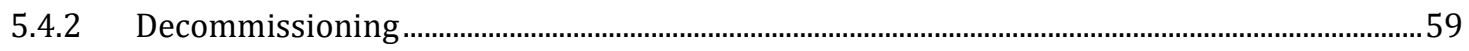

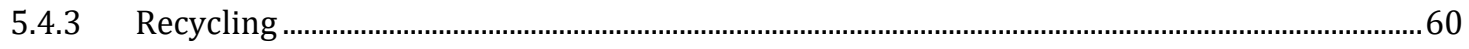

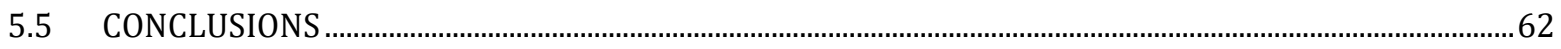

6. OVERVIEW OF COMMON WASTES AND DECOMMISSIONING PROCEDURES FROM THE

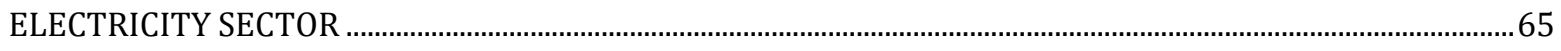

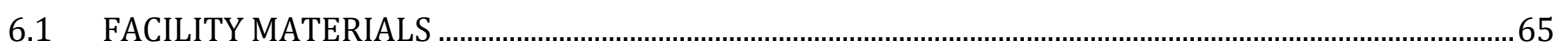

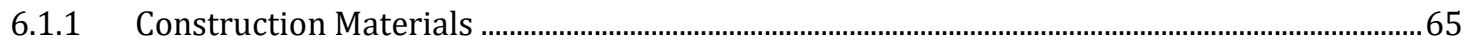

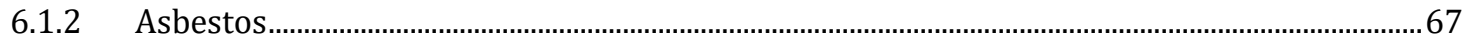

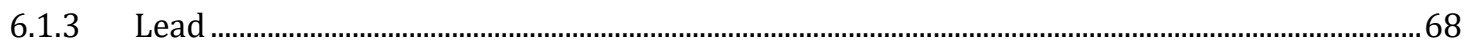

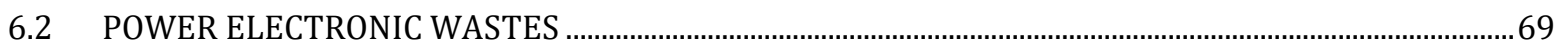

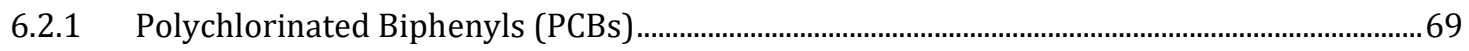

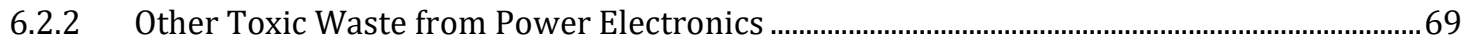

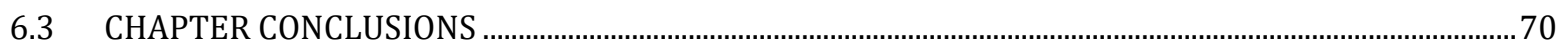

7. LOCAL ECONOMIC AND COMMUNITY IMPACTS OF RETIREMENTS ……........................................................... 71

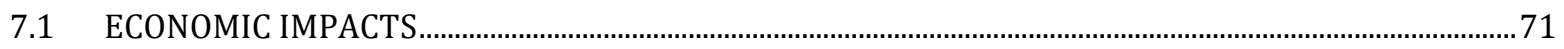

7.2 OTHER COMMUNITY IMPACTS …………………........................................................................................

8. SUMMARY 


\section{EXECUTIVE SUMMARY}

This baseline report examines the solid waste generated by the U.S. electric power industry, including both waste streams resulting from electricity generation and wastes resulting from the decommissioning of power plants.

Coal and nuclear plants produce large volumes of waste during electricity generation, and this report describes the policies and procedures for handling these materials. Additionally, the changing electricity sector is leading to large numbers of plant retirements, resulting in an influx of waste streams from decommissioning activities. The procedures for handling these decommissioning wastes, as well as the closure or maintenance of waste storage facilities, are outlined in the report. Although few renewable plants are currently ready for retirement, decommissioning strategies for these plants are also discussed, as they will eventually reach retirement.

The two largest forms of solid waste from coal-fired generation are coal ash (from the combustion of coal), and "scrubber" slurry (from environmental controls at the plant). Collectively, these two wastes are called coal combustion residues, or CCRs. CCRs are the second most abundant waste material in the United States, after household waste. There is no model approach in place in the U.S. for preparing retirement plans for large fossil generation plants. Environmental remediation will likely be the most expensive phase of many coal decommissioning projects. (The value of the scrap metal from coal plants on the open market can offset some of the cost of demolition. However, going forward there is likely to be a glut of scrap supply, which will make such opportunities more difficult.)

Similarly, nuclear power plants produce waste that must be considered when plants retire. About 72,000 metric tons of used fuel is currently stored at reactor sites across the U.S., with about 70 percent in pool storage and 30 percent stored in concrete casks. The amount of waste in storage grows by about 3 percent annually. There is currently no centralized permanent disposal facility for commercial used nuclear fuel in the U.S., so this radioactive material is stored at reactor sites in 35 states awaiting construction of a permanent handling facility. The NRC operating licenses for about $60 \%$ of the nuclear units in the U.S. will expire by 2040 , which without further license extensions, will create a boom of retirements and decommissioning wastes over the coming decades.

Natural gas and oil-fired power plants face similar waste challenges. The two solid waste concerns for gas- and oil-fired plants are byproducts from air pollution controls and chemical waste, including the scale, sludge, and scrapings removed from the generator, tanks, and pipelines, that may contain radioactive elements. However, there is little public information about the cost of different decommissioning options for oil and gas facilities.

Renewables considered in this baseline report include hydropower, wind and solar.

- Hydropower dams have few unique waste streams during decommissioning, but sediments in reservoirs are a concern, as they accumulate metals, oils, pesticides, and herbicides from 
runoff, which flow downstream during decommissioning. Precautions for endangered species may need to be considered. Dam removal projects have varied widely in cost due to the range in dam sizes and other factors.

- Given that the majority of the U.S. wind fleet is less than 10 years old, there are few examples in the country of waste from decommissioning or re-powering. Older wind farms in other countries have been re-powered by either upgrading or replacing existing towers and other infrastructure with more efficient turbines and related equipment. For full decommissioning of wind towers, many parts can be sold intact for reuse or broken down for salvage though blades have been reported as hard to recycle. There are no national regulations in the U.S. for decommissioning wind plants.

- Similarly, there are no state or federal regulations in the US for recycling solar panels, but a few solar companies have started recycling programs on a voluntary basis. Some estimates anticipate that the salvage value for metal racks, metal fencing, and panels themselves will outweigh decommissioning costs. There is a lack of information on decommissioning solar PV, as panels have a life expectancy of 20-30 years and a majority have not reached their end of life. The lifetime of a solar inverter is approximately 10 years, and there is also a lack of information on how many inverters have been replaced or if they have any recycling or disposal issues.

Some common decommissioning waste streams and issues impact all generation types. For example, high voltage power electronics, such as switches, inverters, converters, and controllers, allow electric power to be precisely controlled to support long-distance transmission. These devices and other power electronics contain lead, brominated fire retardants, and cadmium in their printed circuit boards, and the disposal of these circuit boards in landfills can cause environmental risk.

While there is no model approach, synergies exist for reuse of generation plant sites after remediation, and examples of industrial and mixed-use repurposing of retired plant sites, particularly former coal plant sites, are emerging. There is a lack of publically available data on decommissioning costs and strategies. A register of decommissioning costs and best practices is only now being assembled, though principally focused on non-renewable plants. 


\section{INTRODUCTION}

This baseline report characterizes the solid waste generated from the operation of power plants and also describes the solid waste produced from the decommissioning of power plants. The inclusion of waste from decommissioning is a timely addendum given that utilities in the United States will likely retire a record number of fossil and nuclear plants over the next decade. 1 The report also addresses the pertinent policies and regulations affecting the handling of solid waste from the electricity generation sector.

For context, the rest of Chapter 1 describes trends in the U.S. electricity generation portfolio and the drivers of plant retirements. Chapters 2 through 5 address the major fuels that are the focus of this report: coal, natural gas and oil, nuclear, and renewables (in particular, hydropower, wind, and solar photovoltaics). Each of these four chapters describes the solid wastes that are unique to a particular source of electricity, including the waste produced during operation and decommissioning. We do not provide a complete life cycle assessment of solid waste from electricity generation, but we do examine the possible beneficial use of the wastes created by the operation and decommissioning of power plants. In addition, each of these four chapters addresses the pertinent policies and regulations affecting the handling of solid waste as well as the options for decommissioning plants. Chapter 6 focuses on the common waste streams produced by the decommissioning, demolition, and retirement of different types of power plants, including the recycling of demolition waste into beneficial uses, and the management of asbestos, lead-based paint, and toxic waste from power electronics. Chapter 7 characterizes the local economic and community impacts of plant retirements. The findings of this report are summarized in Chapter 8.

\subsection{TRENDS IN THE U.S. ELECTRCITY GENERATION PORTFOLIO}

Approximately 33\% of U.S. electricity came from coal in 2015, down from 39\% in $2014,44 \%$ in 2013, and 53\% in 1990 (Figure 1.1). ${ }^{2}$ During the month of April, 2015, natural gas-generated electricity surpassed coal for the first time in history. ${ }^{3}$ And in 2015, natural gas generated as much electricity as was generated by coal (Figure 1.1). The Energy Information Administration's (EIA) estimates that natural gas-fired generation will exceed coal generation in the U.S. in $2016 .{ }^{4}$ The current downward trend in coal-fired generation began in 2009, due to the combination of hydraulic fracturing and horizontal drilling which made production of natural gas from shales possible, enabling the increased U.S. production of natural gas, leading to a sustained downward shift in natural gas spot prices and increased production from natural gas-fired generators. ${ }^{5}$

The growth of non-hydro renewables, especially wind and solar, has also been notable. The increased use of these renewable resources has been enabled by declining costs in conjunction with state and federal policies, in contrast to natural gas generation, which has been almost entirely market-driven. In 2014, hydropower generation accounted for half of U.S. renewable electricity; in 2015, hydropower was surpassed by generation from other renewable energy sources for the first time since the expansion of U.S. hydropower over the last century (Figure 1.1). For more detailed 
information on current generation trends and drivers, see the Generation ${ }^{6}$ and Environmental ${ }^{7}$ Baseline Reports.

Figure 1.1 U.S. Electricity Generation by Fuel Source in $2015^{8}$

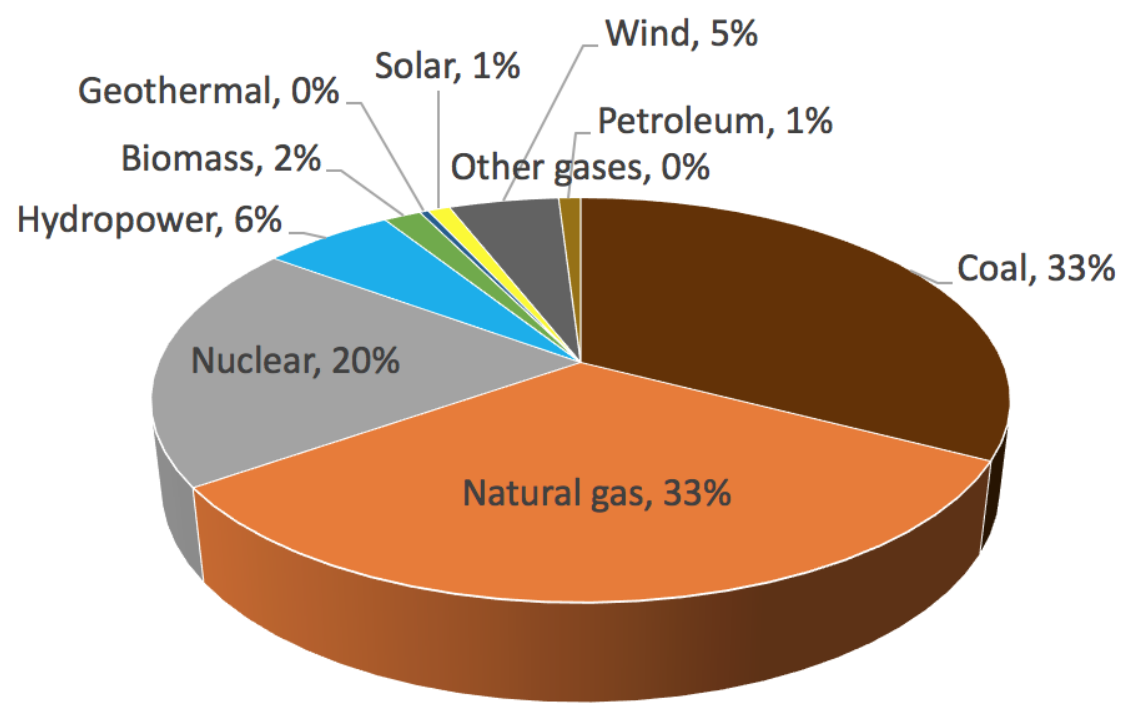

\subsection{DRIVERS OF POWER PLANT RETIREMENTS}

All power plants have a finite life beyond which it is no longer economically viable to operate them. The decision to operate, idle, or retire a power plant is based on a complex set of factors that impact the likelihood that a plant will be able to deliver cost-competitive electricity in the future. Plants become less efficient and less profitable over their lifetimes, unless significant investments are made to replace degraded parts and upgrade components. The global economic downturn in 2008 followed by the sluggish recovery of demand in recent years has challenged electric utilities, some of which have significant overcapacity as indicated by their increasing reserve margins. This has led to industry decisions to retire some inefficient plants.

The recent abundance of low-priced natural gas has produced a significant uptick in gas-fired generation that has driven down the demand for other forms of electricity generation. Retirements of older coal, petroleum, and single-cycle natural gas plants are also motivated by environmental regulations addressing air, water, and solid waste pollution. Nuclear plants also face challenges, including additional precautionary expenditures at U.S. nuclear plants triggered by the nuclear incident at Fukushima-Daiichi, and public opposition that can drive utilities to retire their nuclear plants, particularly when they are individual units that cannot benefit from the scale economies of plants that operate two or three nuclear reactors.

The projected levelized cost of electricity (LCOE) from different generating technologies and energy sources also plays a role in retirement decision-making. Through 2020, natural gas is expected to continue to have the lowest LCOE across the major energy resource options, despite having relatively low capacity factors compared with coal and nuclear plants. ${ }^{9}$ Plant lifetimes typically 
range from 30-45 years for natural gas plants to 30-60 years for coal and nuclear plants. Based on historical performance, wind farms have a typical lifetime of 20-30 years and solar power facilities have a lifetime of 30 years, while hydropower plants tend to operate for longer periods. ${ }^{10} \mathrm{All}$ of these factors play unique roles in the retirement decision of managers of different types of power plants.

\subsection{RECENT AND PLANNED POWER PLANT RETIREMENTS}

Examining EIA data on the makeup of recent and planned power plant retirements provides an indication of the types of solid waste from decommissioning activities that are likely to be generated in the near term (Table 1.1). ${ }^{11}$ The statistics are based on GW of summer power plant capacity. 1213

Over the past six years (from 2010 through 2015), $70.7 \mathrm{GW}$ of summer capacity has been retired. These recent retirements have been dominated by coal plants that account for $52.5 \%$ of recently retired summer capacity. In 2015, nearly $18 \mathrm{GW}$ of coal capacity was shut down. Natural gas steam turbines account for the next largest type of retired plant, comprising $19.4 \%$ of recently retired summer capacity, followed by oil steam turbines at $8.3 \%$, natural gas combustion turbines at $5 \%$, nuclear at 3.2\%, and diesel combustion turbines at 3.1\%.

Over the next five years (between 2016 and 2020), 24 GW of summer capacity is planned to be retired (Table 1.1), and 70\% of this planned retirement capacity comes from coal plants. The next largest type of planned retirement comes from natural gas (22\%). A much smaller percentage of planned retirements are diesel combustion and oil steam turbines. These are less prominent in planned retirements, in part because they now represent a much smaller capacity of the nation's electricity generation than historically has been the case.

These planned retirements are smaller than recent retirements in terms of total summer capacity. The difference is partly due to the fact that planned additions over a 5-year forecast period cannot be fully anticipated; as a result, these EIA data will likely underrepresent the actual pace of future retirements. However the overall conclusion from this analysis is that, in the short-run, coal retirements will continue to be the dominate type of plant retirements in the U.S. power sector. They will therefore be major contributors to the production of solid waste from decommissioning in the electricity sector, with associated risks and opportunities. 
Table 1.1. Recent and Planned Power Plant Retirements in the U.S. 14

\begin{tabular}{|c|c|c|c|c|c|c|c|c|c|c|c|}
\hline & & \multicolumn{8}{|c|}{ Past Retirements: 2010-2015 } & \multicolumn{2}{|c|}{$\begin{array}{l}\text { Planned } \\
\text { Retirements: } \\
\text { 2016-2020 }\end{array}$} \\
\hline \multicolumn{2}{|c|}{$\begin{array}{l}\text { Retirements in } \\
\text { GW of Summer Capacity }\end{array}$} & 2010 & 2011 & 2012 & 2013 & 2014 & 2015 & \multicolumn{2}{|l|}{ Totals } & \multicolumn{2}{|l|}{ Totals } \\
\hline Coal & & 1.4 & 2.6 & 9.2 & 5.8 & 4.2 & 13.7 & 37.1 & $52.5 \%$ & 16.7 & $70.2 \%$ \\
\hline \multirow{4}{*}{ Natural Gas } & Combined Cycle & 0.0 & 0.2 & 0.3 & 0.4 & 1.2 & 0.1 & 2.2 & $3.1 \%$ & 0.3 & $1.3 \%$ \\
\hline & Steam Turbine & 1.2 & 1.3 & 2.6 & 4.9 & 2.2 & 1.5 & 13.7 & $19.4 \%$ & 4.4 & $18.5 \%$ \\
\hline & $\begin{array}{l}\text { Combustion Turbine } \\
\text { and Internal } \\
\text { Combustion Engine }\end{array}$ & 0.2 & 0.2 & 0.9 & 0.6 & 0.4 & 1.3 & \multirow[t]{2}{*}{3.5} & $5.0 \%$ & 0.6 & $2.5 \%$ \\
\hline & Other Gas & 0.0 & 0.0 & 0.0 & 0.0 & 0.0 & 0.0 & & $0.1 \%$ & 0.0 & $0.0 \%$ \\
\hline \multirow{2}{*}{$\begin{array}{l}\text { Petroleum Liquids } \& \\
\text { Coke }\end{array}$} & $\begin{array}{l}\text { Diesel Combustion } \\
\text { Turbine }\end{array}$ & 0.2 & 0.3 & 0.2 & 0.3 & 0.5 & 0.7 & \multirow{2}{*}{$\begin{array}{l}2.2 \\
5.9\end{array}$} & \multirow{2}{*}{$\begin{array}{l}3.1 \% \\
8.3 \%\end{array}$} & \multirow{2}{*}{0.3} & \multirow{2}{*}{$\begin{array}{l}1.3 \% \\
1.7 \%\end{array}$} \\
\hline & Oil Steam Turbine & 1.7 & 1.0 & 1.0 & 1.6 & 0.5 & 0.2 & & & & \\
\hline \multicolumn{2}{|l|}{ Nuclear } & 0.0 & 0.0 & 0.0 & 3.6 & 0.6 & 0.0 & 4.2 & $3.2 \%$ & 0.6 & $0.5 \%$ \\
\hline \multicolumn{2}{|l|}{ Renewable } & 0.2 & 0.2 & 0.4 & 0.3 & 0.4 & 0.2 & 1.7 & $2.4 \%$ & 0.4 & $1.7 \%$ \\
\hline \multicolumn{2}{|l|}{ Other } & 0.0 & 0.0 & 0.0 & 0.0 & 0.0 & 0.0 & 0.1 & $0.1 \%$ & 0.0 & $0.0 \%$ \\
\hline \multicolumn{2}{|l|}{ Yearly Total } & 4.9 & 5.7 & 14.6 & 17.5 & 10.1 & 17.8 & 70.7 & $100 \%$ & 23.8 & $100 \%$ \\
\hline
\end{tabular}

Note: Cumulative retirements after December 31, 2015.

\subsection{OVERVIEW OF SOLID WASTE STREAMS FROM SIX SOURCES OF ELECTRICITY}

Table 1.2 provides an overview of the solid waste streams from the six electricity fuels that are the focus of this report: coal, natural gas and oil, nuclear, hydropower, wind, and solar photovoltaics. The overview summarizes the solid wastes that are associated with different sources of electricity, distinguishing between the waste produced during operation and the waste that occurs with decommissioning.

Conventional fuels (coal, natural gas, oil, and nuclear) using older energy technologies have well known solid waste generation from fuel consumption, on-site fuel storage, waste storage and management, and the re-use of waste and recycling. These are called operational wastes, and they are diverse as shown in Table 1.2. For example, coal-fired power plants produce coal ash and scrubber slurries, while nuclear power plants produce low- and high-level nuclear waste. All fossil fuels (coal, gas and oil) generate $\mathrm{CO}_{2}$ and other air pollutants such as $\mathrm{SO}_{2}, \mathrm{NO}_{\mathrm{x}}$, and particulate matter. We cover these air pollutant issues in this report only to the extent that they have solid waste consequences. Renewable energy technologies, on the other hand, produce little, if any, solid waste during their operation, as shown in Table 1.2. 
Plants powered by conventional fuels also have a variety of decommissioning waste streams. As shown in Table 1.3, fossil and nuclear plants, hydropower, wind, and solar photovoltaics facilities all produce significant decommissioning waste streams.

The details behind the entries in Tables 1.2 and 1.3 are found in subsequent chapters. These chapters also highlight the fact that the solid waste streams from electricity generation depend not only on the fuels and technologies used to operate power plants, but also on the age and design of the plants and the infrastructure that must be decommissioned when the plants retire. As a result, the chapter on solid wastes from coal plants distinguishes between pulverized coal-fired power plants, fluidized-bed coal plants, and integrated gasification combined cycle plants. It also distinguishes between types of environmental remediation, furnaces, and other equipment and systems that impact the nature of the solid waste streams.

Table 1.2. Overview of Solid Waste Streams from Fossil-Fuel and Nuclear Plants

\begin{tabular}{|c|c|c|c|}
\hline & Coal & Natural Gas \& Oil & Nuclear \\
\hline \multicolumn{4}{|c|}{ Unique Fuel, Waste, Recycling, and Storage Issues } \\
\hline $\begin{array}{l}\text { Waste from Fuel } \\
\text { Consumption }\end{array}$ & $\begin{array}{l}\text { Coal combustion byproducts (fly } \\
\text { ash, bottom ash, slag, scrubber } \\
\text { slurries), limited radioactive coal } \\
\text { ash removed at decommissioning }\end{array}$ & $\begin{array}{l}\text { Limited radioactive sludge } \\
\text { removed at decommissioning }\end{array}$ & $\begin{array}{l}\text { Nuclear waste (high- and } \\
\text { low-level nuclear waste) }\end{array}$ \\
\hline $\begin{array}{l}\text { Waste } \\
\text { Storage/Management }\end{array}$ & $\begin{array}{l}\text { Wet ponds and dry } \\
\text { impoundments }\end{array}$ & & $\begin{array}{l}\text { Spent fuel pools and dry } \\
\text { casks }\end{array}$ \\
\hline $\begin{array}{l}\text { Beneficial Uses of } \\
\text { Waste/Recycling }\end{array}$ & $\begin{array}{l}\text { Gypsum board, concrete blocks, } \\
\text { highway construction, road } \\
\text { embankments, ice traction } \\
\text { control, blasting materials, grit } \\
\text { on roof shingles }\end{array}$ & & $\begin{array}{l}\text { While currently prohibited } \\
\text { in the United States, other } \\
\text { countries recycle spent } \\
\text { nuclear fuel }\end{array}$ \\
\hline $\begin{array}{l}\text { On-Site Fuel } \\
\text { Storage/Management }\end{array}$ & Aboveground coal piles & $\begin{array}{l}\text { Above and underground gas } \\
\& \text { oil tanks and pipes }\end{array}$ & Nuclear fuel rods \\
\hline
\end{tabular}

Common Decommissioning Waste Streams

\begin{tabular}{l|l|l|l}
\hline Powerhouse Equipment & $\begin{array}{l}\text { Generators, turbines, boilers, } \\
\text { precipitators, pumps }\end{array}$ & $\begin{array}{l}\text { Generators, turbines, boilers, } \\
\text { precipitators, pumps }\end{array}$ & Generators, pumps \\
\hline Structures & $\begin{array}{l}\text { Buildings, pads and cooling } \\
\text { towers }\end{array}$ & $\begin{array}{l}\text { Buildings, pads and cooling } \\
\text { towers }\end{array}$ & $\begin{array}{l}\text { Buildings, pads and cooling } \\
\text { towers }\end{array}$ \\
\hline T\&D Equipment & $\begin{array}{l}\text { Cables, Wiring, Transmission } \\
\text { Towers, Poles, Underground } \\
\text { Cables }\end{array}$ & $\begin{array}{l}\text { Cables, Wiring, Transmission } \\
\text { Towers, Poles }\end{array}$ & $\begin{array}{l}\text { Cables, Wiring, } \\
\text { Transmission Towers, Poles }\end{array}$ \\
\hline Power Electronics & $\begin{array}{l}\text { Inverters, transformers and } \\
\text { other power electronics }\end{array}$ & $\begin{array}{l}\text { Inverters, transformers and } \\
\text { other power electronics }\end{array}$ & $\begin{array}{l}\text { Inverters, transformers and } \\
\text { other power electronics }\end{array}$ \\
\hline Transport Infrastructure & Railway spurs and access roads & Pipelines and access roads & Access roads \\
\hline $\begin{array}{l}\text { Recyclable/Salvageable } \\
\text { Decom. Wastes }\end{array}$ & Steel, copper, brick, concrete & Steel, copper, brick, concrete & Steel, copper, brick, concrete \\
\hline
\end{tabular}


Table 1.3. Overview of Solid Waste Streams from Renewable Electricity Plants

\begin{tabular}{|c|c|c|c|}
\hline & Hydropower & Wind & Solar Photovoltaics \\
\hline \multicolumn{4}{|c|}{ Unique Fuel, Waste, Recycling, and Storage Issues } \\
\hline Waste from Fuel Consumption & -- & -- & -- \\
\hline Waste Storage/Management & -- & -- & -- \\
\hline $\begin{array}{l}\text { Beneficial Uses of } \\
\text { Waste/Recycling }\end{array}$ & -- & -- & \\
\hline On-Site Fuel Storage & $\begin{array}{l}\text { Water reservoirs with } \\
\text { attendant siltation issues }\end{array}$ & -- & -- \\
\hline \multicolumn{4}{|c|}{ Common Decommissioning Waste Streams } \\
\hline Powerhouse Equipment & $\begin{array}{l}\text { Generators, hydro-turbines, } \\
\text { pumps }\end{array}$ & $\begin{array}{l}\text { Towers, blades, gearbox, } \\
\text { generator, nacelle }\end{array}$ & Solar photovoltaic panels \\
\hline Structures & Dams and buildings & Poles and blades & Steel frames \\
\hline T\&D Equipment & Cables and wiring & Cables and wiring & Cables and wiring \\
\hline Power Electronics & $\begin{array}{l}\text { Inverters, transformers and } \\
\text { other power electronics }\end{array}$ & $\begin{array}{l}\text { Inverters, transformers and } \\
\text { other power electronics }\end{array}$ & $\begin{array}{l}\text { Inverters, transformers and } \\
\text { other power electronics }\end{array}$ \\
\hline Transport Infrastructure & Access roads & Access roads & Access roads \\
\hline $\begin{array}{l}\text { Recyclable/Salvageable Decom. } \\
\text { Wastes }\end{array}$ & Steel, concrete, copper & Steel, copper, fiberglass & $\begin{array}{l}\text { Recycling of steel, glass, } \\
\text { silicon wafers, and rare } \\
\text { earth elements }\end{array}$ \\
\hline
\end{tabular}




\section{COAL}

\subsection{OVERVIEW OF COAL TECHNOLOGY}

The coal ash byproduct of coal-fired power plants is the largest quantity of solid waste produced from the generation of electricity. ${ }^{15}$ The composition and quantity of this solid waste depends on the type of coal burned, the power conversion technology used, and the addition of environmental controls. These factors are discussed below, along with pertinent regulations and options for waste management, beneficial utilization of byproducts from coal combustion, the decommissioning of coal plants, and the reuse of coal plant sites.

\subsubsection{Pulverized Coal-Fired Power Plants}

Conventional coal-fired power plants burn pulverized (powdered) coal to boil water and create steam. The steam, in turn, drives a turbine, which drives the electricity generator based on electromagnetic induction. ${ }^{16}$ Coal plants (like nuclear plants) are principally adapted to base-load operation because they are expensive to start up and shut down. The coal-fired generating process is shown in Figure 2.1.

\section{Figure 2.1. Pulverized Coal-Fired Power Plant ${ }^{17}$}

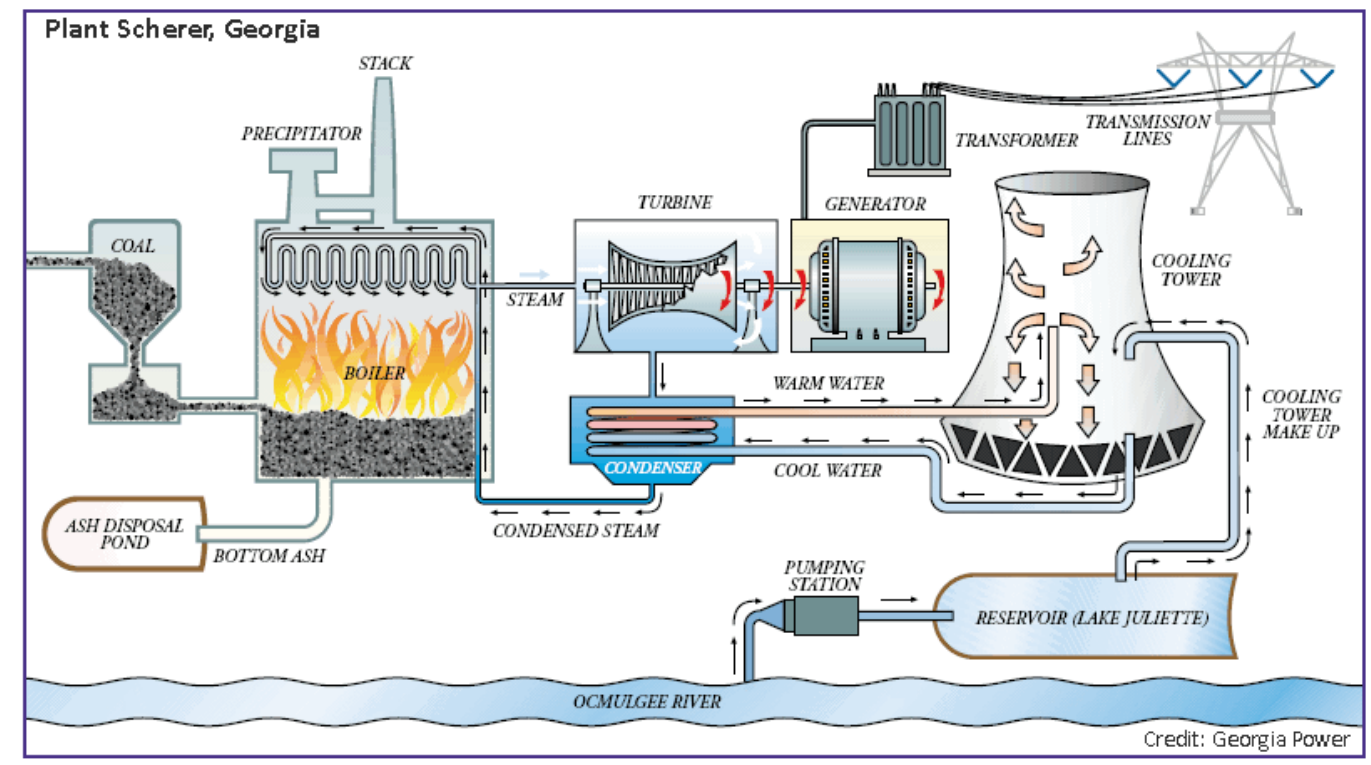

In 2011, approximately half of new coal-fired plants built globally possessed high-efficiency, lowemissions (HELE) technologies, and it is likely that this percentage is higher today. ${ }^{18}$ American coal plants with these technologies include the James E. Rodgers Energy Complex (Cliffside) and the John W. Turk, Jr. UPC. ${ }^{19}$ While proliferation of HELE technologies has increased rapidly over the last decade, about $75 \%$ of all global coal-fired plants lack these technologies. ${ }^{20}$ Further improvements in efficiency have been achieved through supercritical and ultra-supercritical power plants. These technologies allow plants to operate at pressures and temperatures (over 1,100 degrees Fahrenheit) that are higher than the supercritical state of water, when gas and liquid are in equilibrium. Thus, the water is heated above its boiling point without boiling. This creates a more 
efficient steam cycle that produces fewer solid wastes, consumes less fuel, and lowers operating costs. ${ }^{21}$

At least two types of control systems can be used to reduce $\mathrm{SO}_{2}$ emissions from pulverized coal plants. The most common is an external emission control called flue gas desulfurization (FGD) (or "scrubbers"), which remove $\mathrm{SO}_{2}$ and other pollutants from the flue gas, generally with a basic solid or solution.

\subsubsection{Fluidized-Bed Coal Plants}

Fluidized-bed combustion (FBC) is a more recent power-generation technology that has evolved from efforts to find a combustion process able to control pollutant emissions without external emission controls. The combustion process consists of suspending coal with jets of air that create a mixing of gas and solids. The interaction of the flue gas and a sulfur absorbing chemical can capture over $95 \%$ of sulfur pollutants. The plant operates at temperatures of about 1,500 degrees Fahrenheit, about 1,000 degrees lower than the threshold for nitrogen oxides formation. ${ }^{22} \mathrm{An}$ estimated 1,000 MW of capacity with FBC is installed worldwide; however, the only United States example was the joint DOE-American Electric Power Clean Coal Technology project at the Tidd Plant in Ohio, which was decommissioned in 2015. Both of these air pollution abatement technologies, FGD and FBC, produce solid waste, as described below.

\subsubsection{Integrated Gasification Combined Cycle (IGCC) Plants}

A newer approach to the conversion of coal to electricity is the integrated gasification combined cycle (IGCC). IGCC generators use a gasifier under high temperatures without combustion to create "syngas" from coal. Syngas is generally around 45\% carbon monoxide (CO), 28\% hydrogen $\left(\mathrm{H}_{2}\right), 8 \%$ carbon dioxide $\left(\mathrm{CO}_{2}\right)$, and $3 \%$ methane $\left(\mathrm{CH}_{4}\right)$. Additional constituents in syngas frequently include other gases and contaminants including hydrogen sulfide $\left(\mathrm{H}_{2} \mathrm{~S}\right)$, ammonia, and water vapor. ${ }^{23}$ In fixed (moving) bed gasifiers, reactions occur in multiple "zones". ${ }^{24}$ At the top of the gasifier is the "drying zone." 25 Here, coal that has entered is heated and dried while cooling the product gas before exiting the reactor. In the "carbonization zone", warmer temperature gas further heats the coal. ${ }^{26}$ Next, coal is gasified with $\mathrm{CO}_{2}$ and steam in the "gasification zone." 27 Finally, the hottest temperatures occur near the bottom of the gasifier in the "combustion zone."28 Here, oxygen reacts with the remaining char. ${ }^{29}$ In the case of an IGCC plant with carbon capture and storage (Discussed in greater detail in 2.1.4), the gas turbine is adjusted so syngas can be burned with essentially no $\mathrm{CO}{ }^{30}$ With a reactor containing shift catalysts, the following reaction occurs: $\mathrm{CO}+\mathrm{H}_{2} \mathrm{O} \rightarrow \mathrm{CO}_{2}+\mathrm{H}_{2}$. The hydrogen is then combusted to run a combustion turbine. The exhaust heat from the combustion turbine drives a secondary heat recovery system to generate steam to run a steam turbine that also drives an electricity generator. ${ }^{31}$ Another gasifier that has been used for IGCC is the GE energy gasifier. In this gasifier, syngas is created from a "single-stage, downward feed, entrained-flow refractory lined reactor."32

Today, three IGCC plants operate in the United States. The Wabash River Repowering Project can supply 262 MW to the electric grid. 33 Tampa Electric's Polk Power Station can supply 250 MW to the electric grid. ${ }^{34}$ The most recent plant, Duke Energy's Edwardsport Generating Station, is a 618 
MW IGCC plant. ${ }^{35}$ At full capacity, the plant can generate energy for about 500,000 houses. Three IGCC plants in Europe have electricity capacities of 430 MW, 300 MW, and 253 MW, respectively. 36 In addition to future planned IGCC plants in the United States, additional IGCC plants are anticipated to go online in China, India, Japan, Pakistan, Saudi Arabia, South Korea, and the United Kingdom in the coming years. ${ }^{37}$ For additional information on these technology trends, see the Generation Baseline report. ${ }^{38}$

\subsubsection{Carbon Capture and Storage}

Carbon capture and storage (CCS) is being deployed at coal plants to reduce the $\mathrm{CO}_{2}$ emissions and may also be applied to natural gas plants in the future. Many industrial processes (such as ethanol production or fertilizer production) produce purer streams of $\mathrm{CO}_{2}$ than power plants, making $\mathrm{CCS}$ cheaper for these industrial streams.

Carbon dioxide can be captured post- or pre-combustion. Post-combustion capture extracts $\mathrm{CO}_{2}$ from the flue gases produced in the conventional air-fired combustion process - after combustion of coal (or natural gas). This is an approach that can be used in conventional power plants, and it is well understood because it has been used for several decades in other industrial applications, although at somewhat more limited scales. The most common technology employed today is aminebased chemical absorption. Amine, a nitrogen-based chemical, is able to rapidly react with $\mathrm{CO}_{2}$ in the flue gas to separate it. Specifically, the capture equipment includes an absorption tower, in which flue gases come in contact with droplets of amines that selectively absorb $\mathrm{CO}_{2}$. In a second reaction column, known as a stripper tower, the amine liquid is heated to release concentrated $\mathrm{CO}_{2}$ and to regenerate the chemical absorber. Flue gases are only 10 to $12 \% \mathrm{CO}_{2}$ by volume for coal power plants and even less, 3 to $6 \%$, for natural gas-fired power plants. ${ }^{39}$

Pre-combustion capture involves the syngas via a shift catalyst to separate and remove $\mathrm{CO}_{2}$ and hydrogen. $\mathrm{CO}_{2}$ is then transported to a process facility where it is compressed, injected, and stored underground. ${ }^{40}$ The water-gas shift reaction occurs in some gasification configuration, stripping some of the $\mathrm{CO}_{2}$ for the process to work. The water-gas shift reaction used in pre-combustion capture is already applied to hydrogen production, which is generated at large scale for making fertilizer. ${ }^{41}$

In both cases, compressed $\mathrm{CO}_{2}$ can be used for enhanced oil recovery in the oil and gas industry and for coal mine methane production. ${ }^{42} \mathrm{CCS}$ can reduce $\mathrm{CO}_{2}$ in both gas and coal generation. CCS offers the potential to significantly reduce $\mathrm{CO}_{2}$ emissions from coal-fueled electricity generation. ${ }^{43}$

IGCC plants with CCS generally have higher operating efficiencies than conventional coal-fired power plants. Compared to conventional plants, IGCC plants with CCS produce less coal ash per MWh generated since they gasify rather than combust coal. IGCC plants with CCS have similar operating characteristics to that of combined cycle combustion turbines. However, the IGCC with CCS plants are less efficient than combined cycle turbines largely because the coal gasification process is energy intensive. 
Figure 2.2. Post-Combustion CCS Plant ${ }^{44}$

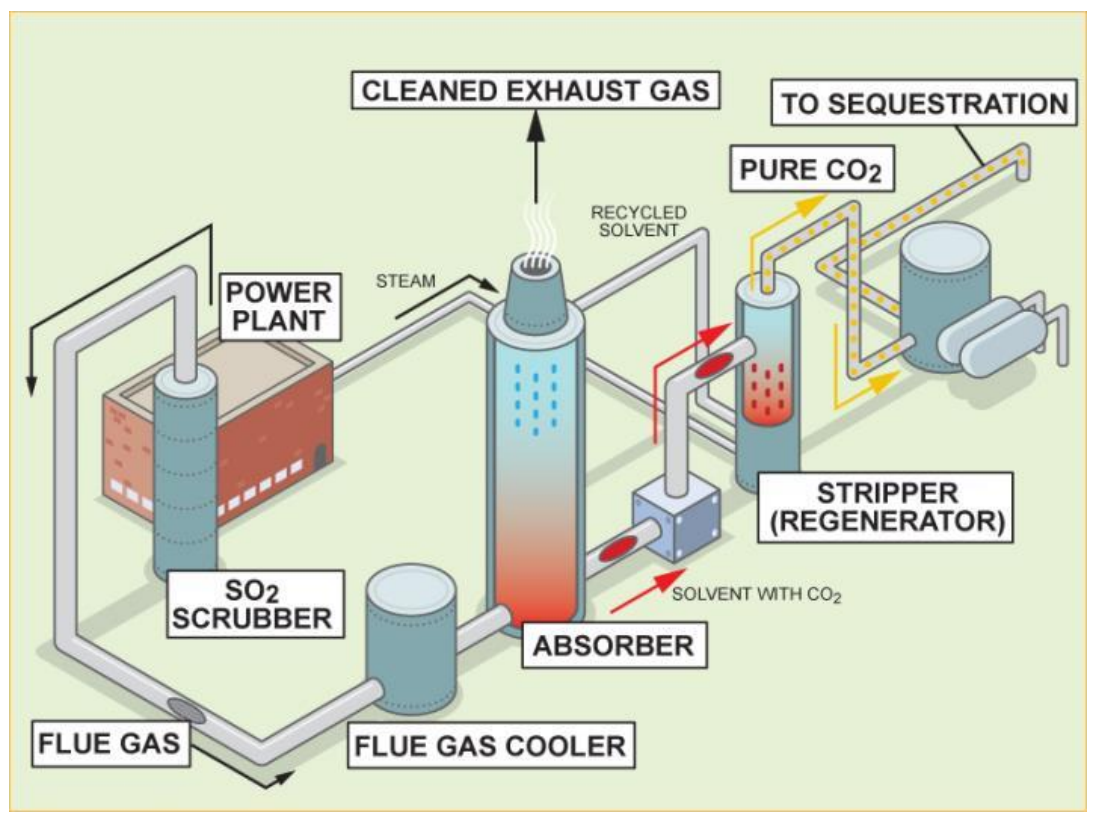

$\mathrm{CO}_{2}$ capture is similar to other environmental scrubbers applied to coal and other fossil-fueled power plants, although the energy penalty for CCS is much bigger than for conventional pollution control. Adding another environmental control comes with an associated energy penalty. This means that for each unit of energy (coal) burned, less electricity is sold on the grid.

\subsubsection{Other Coal Technologies}

Additional technologies include selective catalytic reduction (SCR) and selective non-catalytic reduction $\mathrm{NO}_{\mathrm{x}}$ controls. ${ }^{45}$ These technologies produce minimal solid waste streams. ${ }^{46}$

\subsection{WASTE GENERATION AND MANAGEMENT}

The two largest forms of solid waste from coal-fired generation are coal ash, which results from the combustion of coal, and scrubber slurry, which results from emissions reduction efforts at the plant. Different types of scrubbers have different types of waste streams.

\subsubsection{Coal Ash}

In 2014, roughly 130 million tons of coal ash, also known as coal combustion residuals (CCRs), were generated, making it the third most common mineral resource in the United States. ${ }^{47} 48$ With 1.5 billion tons of coal ash stockpiled, coal ash is the second most abundant waste material (after household waste) in the United States..$^{49}$ On average, for every six tons of coal burned, one ton of coal ash is produced..$^{50}$ In 2012, electric utilities burned over 800 million tons of coal and generated approximately 110 million tons of CCRs in 47 states and Puerto Rico. ${ }^{51}$

Coal ash is comprised of the solid particles that remain after coal combustion. "Bottom ash" refers to the particles that remain at the bottom of the coal combustion chamber in a pulverized coal plant while "fly ash" refers to the particles that fly into the cooling stacks. ${ }^{52} 53$ Slag is a type of ash that 
results from burning crushed coal at intense temperatures in a cyclone boiler. This produced slag is a "coarse, hard, black, angular, glassy material." 54

Table 2.1 provides a comparison of integrated gasification combined cycle (IGCC), fluidized-bed combustion (FBC), and pulverized coal (PC) plants in terms of their byproducts and waste levels. The table was created for a $300 \mathrm{MW}$ size plant that uses Illinois bituminous coal with $4 \%$ sulfur content. Bituminous coal is the most common coal used to generate electricity in the United States and also has a carbon content that varies greatly. ${ }^{55}$ The table illustrates that a representative 300 MW PC plant using wet FGD produces 557 tons/day of ash (dry weight), while a model FBC system of the same capacity produces slightly less, at 538 tons/day). In contrast, an IGCC plant produces 515 tons/day of slag that is non-existent at the plants that possess FBC technology or use PC. 56 
Table 2.1 Solid Waste Streams of Pulverized Coal with Wet FGD, Fluidized Bed Coal, and IGCC Power Plants $^{57}$

\begin{tabular}{|c|c|c|c|}
\hline Plant Data & $\begin{array}{l}\text { Pulverized Coal } \\
\text { Plant with } \\
\text { Advanced Wet FGD }\end{array}$ & $\begin{array}{l}\text { Fluidized Bed Coal } \\
\text { Plant }\end{array}$ & $\begin{array}{l}\text { IGCC Plant } \\
\text { (Without CCS) }\end{array}$ \\
\hline \multicolumn{4}{|l|}{ Plant Operating Data } \\
\hline Plant Size, MWe & 300 & 300 & 300 \\
\hline Annual Capacity Factor, \% & 65 & 65 & 65 \\
\hline Heat Rate, Btu/kWh & 9,750 & 9,400 & $9,000^{\mathrm{ii} 58}$ \\
\hline Carbon Conversion, $\%$ & 99 & 98 & 99 \\
\hline Feed Fuel, tons/day & 3,480 & 3,360 & 3,216 \\
\hline Feed Limestone, tons/day & 466 & 1,104 & - \\
\hline \multicolumn{4}{|l|}{ Fuel Properties } \\
\hline HHV, Btu/lb & 10,100 & 10,100 & 10,100 \\
\hline Sulfur, Weight \% & 4 & 4 & 4 \\
\hline Ash, Weight $\%$ & 16 & 16 & 16 \\
\hline Carbon, weight $\%$ & 57.6 & 57.6 & 57.6 \\
\hline \multicolumn{4}{|l|}{ Sulfur Removal* } \\
\hline Removal Efficiency, \% & 95 & 95 & 98 \\
\hline Sorbent & Limestone & Limestone & MDEA** $^{* *}$ \\
\hline Limestone Purity, \% & 95 & 95 & - \\
\hline $\mathrm{Ca} / \mathrm{S}$ Molar Ratio & 1.02 & 2.5 & - \\
\hline Water on Dry Waste, \% & 25 & 25 & 25 \\
\hline \multicolumn{4}{|l|}{ Solids Generated, tons/day } \\
\hline Ash (Dry) & 557 & 538 & 0 \\
\hline Slag (Dry) & 0 & 0 & 515 \\
\hline Carbon in Ash (Dry) & 20 & 19 & 19 \\
\hline Elemental Sulfur & 0 & 0 & 126 \\
\hline $\mathrm{CaSO}_{4}$ (Anhydrite) & 562 & 542 & 0 \\
\hline $\mathrm{CaO}$ (Dry) & 10 & 363 & 0 \\
\hline Inerts from Limestone & 23 & 55 & 0 \\
\hline \multicolumn{4}{|l|}{ Totals } \\
\hline Total By-Products, tons/dayiii & 747 & 0 & 126 \\
\hline Total Solid Waste, tons/day (Dry) & 577 & 1,778 & 534 \\
\hline Total Solids Generated, tons/day & 1,324 & 1,778 & 660 \\
\hline Total Solids Generated, lb/MWh & 367 & 494 & 183 \\
\hline Total Solid Waste Generated, lb/MWh & 172 & 494 & 148 \\
\hline
\end{tabular}

*Sulfur Removal is discussed in greater detail in 2.2.2 "Scrubber Slurries

** Methyldiethanolamine (MDEA) is an aqueous solution used to remove hydrogen sulfide and carbon dioxide from flue gases.

ii These are heat rates for model plants built with the latest technologies in 2016. Actual heat rates across all coal plants vary widely depending on the age and efficiency of the plant. Heat rates for coal plants operating in 2012 ranged from 8,800 Btu/kWh to $25,000 \mathrm{Btu} / \mathrm{kWh}$.

iii Produced solids that are able to be re-used for beneficial uses 
Depending upon the source and makeup of the coal being burned, the components of coal ash vary considerably. All fly ash and bottom ash include substantial amounts of silicon dioxide $\left(\mathrm{SiO}_{2}\right)$, aluminum oxide $\left(\mathrm{Al}_{2} \mathrm{O}_{3}\right)$, and calcium oxide $(\mathrm{CaO})$, the main mineral compounds in coal-bearing rock. ${ }^{59}$ However, traces of arsenic (As), cadmium (Cd), lead (Pb), mercury ( $\mathrm{Hg}$ ) and other elements are also common in both fly ash and bottom ash (Table 2.2).

Table 2.2 Concentrations of Various Elements in Coal Combustion Products (median values in mg/kg or ppm) ${ }^{60}$

\begin{tabular}{l|llllllllll}
\hline & $\mathrm{As}$ & $\mathrm{Ba}$ & $\mathrm{Cd}$ & $\mathrm{Cr}$ & $\mathrm{Pb}$ & $\mathrm{Hg}$ & $\mathrm{Se}$ & $\mathrm{Ag}$ & $\mathrm{Sb}$ & $\mathrm{Be}$ \\
\hline Fly Ash & 71 & 923 & 1.07 & 133 & 49 & 0.1075 & 11 & $<4.9$ & $<7.2$ & 10.6 \\
Bottom Ash & 7.2 & 768 & $<5.5$ & 191 & 20 & 0.018 & $<1.25$ & $<5.5$ & $<7$ & 5.8 \\
\hline & $\mathrm{B}$ & $\mathrm{Co}$ & $\mathrm{Cu}$ & $\mathrm{Mn}$ & $\mathrm{Ni}$ & $\mathrm{Tl}$ & $\mathrm{V}$ & $\mathrm{Zn}$ & $\mathrm{Fe}$ & $\mathrm{Mo}$ \\
\hline Fly Ash & 322 & 7.9 & 140 & 189 & 102 & 2.4 & 254 & 152 & 69100 & 19 \\
Bottom Ash & 82 & $\mathrm{NA}$ & 73 & 262 & 123 & $<0.5$ & 161 & 59 & 101200 & 11 \\
\hline
\end{tabular}

The composition of coal combustion residues can be changed by altering fuel used at plants or by implementing air emission controls. Examples include mixing coal types or co-firing biomass with coal. Air emission controls include ammonia-based systems that can control $\mathrm{NO}_{\mathrm{x}}$, carbon injected powder that can manage mercury, and $\mathrm{SO}_{2}$ that can be mitigated through sodium-based sorbents and fluidized bed combustion. ${ }^{61}$ These emission control systems create "scrubber slurries," which are described in Section 2.2.2.

\subsubsection{Coal Ash Storage and Management}

Coal ash management sites come in many different sizes, and are typically operated under statepermits. A DOE and EPA study found engineering and regulatory controls of sites became more stringent from the 1990s into the 2000s. ${ }^{62}$ The EPA conducted a thorough review of the impact of coal combustion residuals on the environment and public health. Based on their findings, in April 2015, EPA issued the Disposal of Coal Combustion Residuals from Electric Utilities final rulegenerally known as the CCR Rule.iv The CCR Rule establishes technical requirements for CCR landfills and surface impoundments under subtitle D of the Resource Conservation and Recovery Act (RCRA), v the central federal regulatory program governing recycling and disposal of solid waste. The rule specifies national regulations for the safe handling and disposal of coal ash. ${ }^{63}$ To reduce the risk of accidental release, coal-fired power producers must periodically conduct assessments of structural stability, perform weekly inspections, and develop emergency plans. In addition, there are groundwater specifications, restrictions on impoundment locations, liner design requirements, operating criteria, and record keeping requirements. ${ }^{64}$ Additionally, there are dewatering requirements for inactive units. ${ }^{65}$

\footnotetext{
iv https://www.epa.gov/coalash/coal-ash-rule

v https://www.epa.gov/laws-regulations/summary-resource-conservation-and-recovery-act, Accessed March 21, 2016.
} 
The new dewatering requirements for inactive units mean that retired plants cannot maintain wet ash lagoons. Many of the other requirements will reduce the likelihood of ash pond leakages and impoundment spills. This rule does not apply to disposal of CCRs in abandoned or active underground or surface coal mines. Federal regulations will be created by the EPA and Department of Interior (DOI) in the future so that the placement of future CCR in mine fill operations is adequately controlled.66

In March, The Coal Ash Landfill Safety Act (CALSA) was introduced in the U.S. House of Representatives. ${ }^{67}$ The legislation calls for the EPA to reconsider disposing of coal ash in municipal landfills. ${ }^{68}$ The aim of CALSA is to protect communities from coal ash dust in landfills, during transportation, and other ash management and material handling activities. ${ }^{69}$ Additionally, the bill calls for weekly, monthly, and yearly groundwater inspection requirements, as well as proper clean up mandates..$^{70}$ Other provisions include banning CCRs within five feet of groundwater, and publicly posting monitored data, corrective action plans, and inspection reports to keep the public informed of hazards. ${ }^{71}$

There exist two disposal methods for coal ash. The method employed is based on availability of landfills or impoundments. Coal ash that is stored in the dry form is disposed of in one of the about 300 U.S. landfills located near coal power plants. These landfills on average cover 120 acres and are 40 feet deep. The U.S. coal combustion products that are stored in wet form are disposed of in one of over 700 impoundment sites. On average, these sites measure over 50 acres with a depth of 20 feet. 72

Figure 2.3 Landfills and Surface Impoundments for Coal Combustion Residuals at the TVA Paradise Fossil Fuel Plant ${ }^{73}$

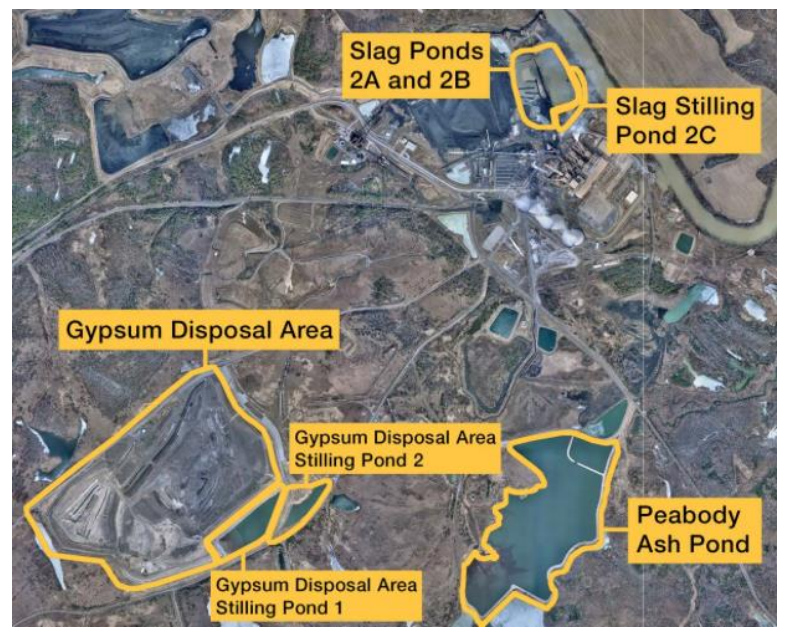

Figure 2.3 shows the landfills and surface impoundments for coal combustion residuals at the TVA Paradise Fossil Fuel Plant near Brakesboro, Kentucky. Coal combustion residue from the three coalfired generating units on site are disposed of separately in ash ponds, slag ponds, and gypsum disposal areas. 
The lack of lining in most ash ponds has resulted in leachate impacting groundwater. ${ }^{74}$ In 2010 , over 30 coal ash disposal sites in multiple states were found to be connected to contaminated water. ${ }^{75}$ The largest release of coal combustion residuals to date occurred in 2008 at an operating coal plant in Kingston, Tennessee, when 300 acres of land were covered with wet coal ash. ${ }^{76}$ Drinking water was monitored and not impacted. This is principally a function of the trace levels of contaminants and the relatively high flowrate in the river. Contaminants of concern were arsenic and selenium. The ash spill was cleaned up at a cost of over $\$ 1$ billion. ${ }^{77} 78$ In 2014 , a storm water drain at a retired coal-fired power plant in North Carolina ruptured, spilling 24 to 27 million gallons of basin water from a 27-acre coal ash reservoir into the Dan River, which is the drinking water source for many communities and is a primary feeder to Kerr Lake Reservoir. As with the TVA spill, drinking water quality was not impacted, largely because of the low concentrations and high dilution factor. ${ }^{79} \mathrm{~A}$ Duke University Nicholas School of Environment study found surface water and groundwater surrounding coal ash ponds at about 20 coal plants in five southeastern states are regularly contaminated due to unlined ponds. ${ }^{80}$ The water tested at all of the sites showed high levels of arsenic and selenium. In over a quarter of the surface water examples, concentrations of trace elements exceeded EPA drinking water and aquatic life standards. ${ }^{81}$ As a result of these concerns, some utilities are voluntarily moving their coal ash out of unlined lagoons to dry landfill storage and away from waterways. In June 2016, the Georgia Power Company announced that it would be closing 16 of its 29 ash ponds at a cost of $\$ 1.5$ to $\$ 2.0$ billion $^{82}$ These actions were chosen since they were seen as financially prudent. 83

The guidelines of the Toxicity Characteristic Leaching Procedure (TCLP) under the Resource Conservation and Recovery Act (RCRA) are intended to prevent such leaching and releases. ${ }^{84}$ Dry ash handling systems generally result in fewer accidental releases and smaller amounts of leachate. ${ }^{85}$ While it is environmentally beneficial for ash ponds to be lined, it is common for them not to be. ${ }^{86}$ However, under the new CCR Rule all new impoundment and landfill sites must be lined. ${ }^{87}$ Exposure to windblown coal ash can be prevented by implementing dust masks and regularly wetting open dry coal ash impoundments. ${ }^{88}$

Another constituent in coal ash is mercury. In 1999, the EPA found that despite implementing safety nets for mercury, three-fifths of mercury captured by fly ash or $\mathrm{SO}_{2}$ control still escaped to the atmosphere. Finally, naturally occurring radioactive constituents, such as uranium, are also found in coal ash. ${ }^{89}$ Oak Ridge National Laboratory studies have found that in the case of a coal plant and a nuclear plant producing the same amount of energy, the fly ash from the coal plant can release up to 100 times the level of radiation produced at a nuclear plant. ${ }^{90}$ This is because some of the radioactive constituents in coal become more concentrated in the ash after burning. ${ }^{91}$ However, the U.S. Geological Survey has concluded that these levels of radioactive constituents are similarly found in naturally occurring granite and shale. ${ }^{92}$ As a result, remediation for radioactivity in ash is not required.

\subsubsection{Beneficial uses of coal ash}

About a decade ago, three-fifths of all coal ash was managed in storage and roughly $40 \%$ was used in beneficial applications, primarily in construction material, by mixing it into concrete and drywall 
products. ${ }^{93}$ Between 2004 and 2014, the mass of fly ash produced from electricity generation decreased from 70 million short tons to 50 million short tons, while the percentage of fly ash reused in beneficial applications increased from 40 to $46 \%$. During the same time period, the mass of bottom ash produced fell from 17 million short tons to 13 million short tons, while the percentage of bottom ash re-used in applications increased from 47 to $49 \%$. ${ }^{94}$ The decrease in ash production corresponded to a reduction in electricity generation at coal power plants. ${ }^{95}$ Nearly $50 \%$ of recycled fly ash is used in concrete products, and about $15 \%$ is used for cement production. The largest beneficial use of bottom ash is for road based materials and structural fill. ${ }^{96}$

Depending on the type of coal burned, different classes of fly ash are created. Class C fly ash is typically produced by burning lignite or subbituminous coal. Class F fly ash is typically produced by burning anthracite or bituminous coal. While class $\mathrm{C}$ fly ash possesses cementing and pozzolanicvi properties, class F generally only possesses pozzolanic properties with limited cementing value. ${ }^{97}$ Approximately half of the concrete poured in the United States contains class C fly ash. ${ }^{98}$ The American Coal Ash Association (ACAA) reports fly ash contains chemical and mechanical properties that produce a durable, strong, and thick concrete that can double the average length of time a highway can be used. ${ }^{99}$ Due to lessened need for virgin extracted materials, use of slag in place of concrete can also reduce carbon dioxide emissions, and produce greater energy savings. ${ }^{100}$ Slag has previously been effectively used as grit on roof shingles and blasting materials. ${ }^{101}$ In addition to use as a structural fill, bottom ash can also be used to blast grit and ice traction control. ${ }^{102}$ However, the recent CCR Rule establishes that the application of non-roadway structural fill greater than 12,400 tons must be in compliance with four criteria to be considered "beneficial use." 103 First, the CCR must provide a functional use. ${ }^{104}$ Second, CCR must substitute for the use of a virgin material, conserving natural resources that would otherwise need to be obtained through practices, such as extraction. ${ }^{105}$ Third, the use of CCR must meet relevant product specifications, regulatory standards, or design standards, when available, and where such specifications or standards have not been established. ${ }^{106}$ Fourth, When unencapsulated use of CCR involving placement on the land of 12,400 tons or more in non-roadway applications, the user must demonstrate and keep records, and provide such documentation upon request, that environmental releases to groundwater, surface water, soil and air are comparable to or lower than those from analogous products made without CCR, or that environmental releases to groundwater, surface water, soil and air will be at or below relevant regulatory and health-based benchmarks for human and ecological receptors during use. ${ }^{107}$ The application of fly ash to mine lands can help to increase the land's alkalinity and capacity to hold water so vegetative cover can expand. ${ }^{108}$ Recycling coal ash also frees up space in landfills.vii 109

Another beneficial use of coal ash has been to remediate coal refuse, a waste product of coal mining that contains coal and other organic and inorganic materials. The greatest quantity of coal refuse in the United States is in western Pennsylvania, with estimates of billions of cubic feet. Piles of coal refuse can occupy hundreds of acres of unreclaimed mine lands resulting from mining operations

\footnotetext{
vi "Having properties of a porous variety of volcanic tuff or ash used in making hydraulic cement." http://www.dictionary.com/browse/pozzolanic vii http://www.osmre.gov/programs/tdt/ccrs.shtm; http://www.osmre.gov/programs/tdt/ccrs/docs/Coal_Combustion Byproducts-ANPRM.pdf
} 
before the establishment of many of today's environmental regulations. Many challenges are associated with coal refuse piles, such as refuse pile fires. Another environmental concern associated with coal refuse piles is that acid runoff containing aluminum, iron, and other metals can leak into surrounding creeks, streams, and rivers. Iron precipitates out of coal refuse piles as solid iron hydroxide, contaminating water and turning it orange. A reclamation project in Revloc, Pennsylvania, lasted over 20 years and cost $\$ 24$ million. ${ }^{110}$ During the project, about three million tons of coal ash was used to neutralize acidic compounds and over three million tons of useable coal refuse was removed from the site. In addition to the 56 acres reclaimed, a nearby creek was able to support aquatic life once more as a result of the project.111

\subsubsection{Scrubber Slurry}

The first and most common $\mathrm{SO}_{2}$ pollution abatement system is flue gas desulfurization (FGD). It removes $\mathrm{SO}_{2}$ and other pollutants from the flue gas with limestone $\mathrm{CaCO}_{3}$ or lime $\mathrm{Ca}(\mathrm{OH})_{2}$, which are used as scrubbers. The reaction of the scrubber with $\mathrm{SO}_{2}$ results in insoluble calcium sulfite $\left(\mathrm{CaSO}_{3}\right)$. Further reactions between oxygen and calcium sulfite can create gypsum $\left[\mathrm{CaSO}_{4} \cdot 2\left(\mathrm{H}_{2} \mathrm{O}\right)\right] \cdot 112$

Wet FGD technologies have been traditionally preferred to dry FGD technologies. Wet FGD technologies saturate exiting flue gas with water, while dry FGD technologies create dry byproducts or materials. The most frequently used wet FGD sorbent is wet limestone, while the most common dry FGD sorbent is lime spray drying. Both technologies are able to remove at least $95 \% \mathrm{of}_{2 .} \mathrm{SO}^{113}$ Both once-through and regenerable FGD processes exist. In the first case, spent sorbent is disposed of or serves as a byproduct for beneficial use. No waste is produced in the second process. ${ }^{114}$ Fluidized-bed combustion (FBC) uses sulfur-absorbing chemicals, such as limestone or dolomite to capture sulfur released by the combustion of coal.viii Based on Table 2.1, a $300 \mathrm{MW}$ coal plant using wet FGD produces 562 tons/day of $\mathrm{CaSO}_{4}$ (Anhydrite), while a $\mathrm{FBC}$ system at the same plant produces slightly less (542 tons/day). In contrast, an IGCC plant captures 126 tons of elemental sulfur from pre-combustion coal gasification.

Once-through processes are less expensive than regenerable, and as such have been utilized more often. ${ }^{115}$ In a once-through process, spent liquids from scrubbing are moved to a clarifier for the water to be reused. Spent solids, in a heavy slurry, are sent to the same ash pond as coal ash, and is removed from the slurry. ${ }^{116}$ Stabilized scrubber material is used in road construction for paving and embankments. ${ }^{117}$ Gypsum co-products such as building materials can be produced with a small energy penalty. In fiscal year 2015, the Tennessee Valley Authority's (TVA) Cumberland Fossil Plant supplied 675,000 tons of gypsum as a feedstock to Georgia Pacific's wallboard plant in Cumberland City, Tennessee. ${ }^{118}$ This accounted for over $80 \%$ of the gypsum produced by the fossil plant during the fiscal year. It also provided $\$ 2.25$ million in revenue and $\$ 18.9$ million in avoided disposal costs for TVA. ${ }^{119}$ Roughly half of wallboards produced in the United States are created from recovered gypsum. Gypsum can also be used to neutralize acidic soil and as a soil conditioner. ${ }^{120}$

\footnotetext{
viii http://energy.gov/fe/science-innovation/clean-coal-research/advanced-combustiontechnologies/fluidized-bed-technology
} 
When methyldiethanolamine (MDEA), an aqueous solution, is used as a scrubber to remove hydrogen sulfide and carbon dioxide from syngas in pre-combustion IGCC plants, $98 \%$ of the sulfur pollutants in coal can be captured.121

\subsubsection{Other Coal Wastes}

Steam electric power plants create about $30 \%$ of all toxic pollutants regulated under the Clean Water Act that are discharged into surface waters during industrial production (Figure 2.4). ${ }^{122}$ In wet FGD systems, the flue gas comes in contact with a liquid stream which contains a sorbent that removes $\mathrm{SO}_{2}$ from the flue gas. As a result, FGD wastewaters usually measure significant levels of chloride, total dissolved solids (TDS), total suspended solids (TSS), and nutrients. Bioaccumulative pollutants, including arsenic, mercury and selenium, are also found in FGD wastewaters. FGD wastewater treatment processes include settling ponds, biological treatment systems, chemical precipitation systems, constructed wetlands, vapor-compression evaporation systems, and other technologies. ${ }^{123}$

Figure 2.4 Major sources of wastewater from coal power plants ${ }^{124}$

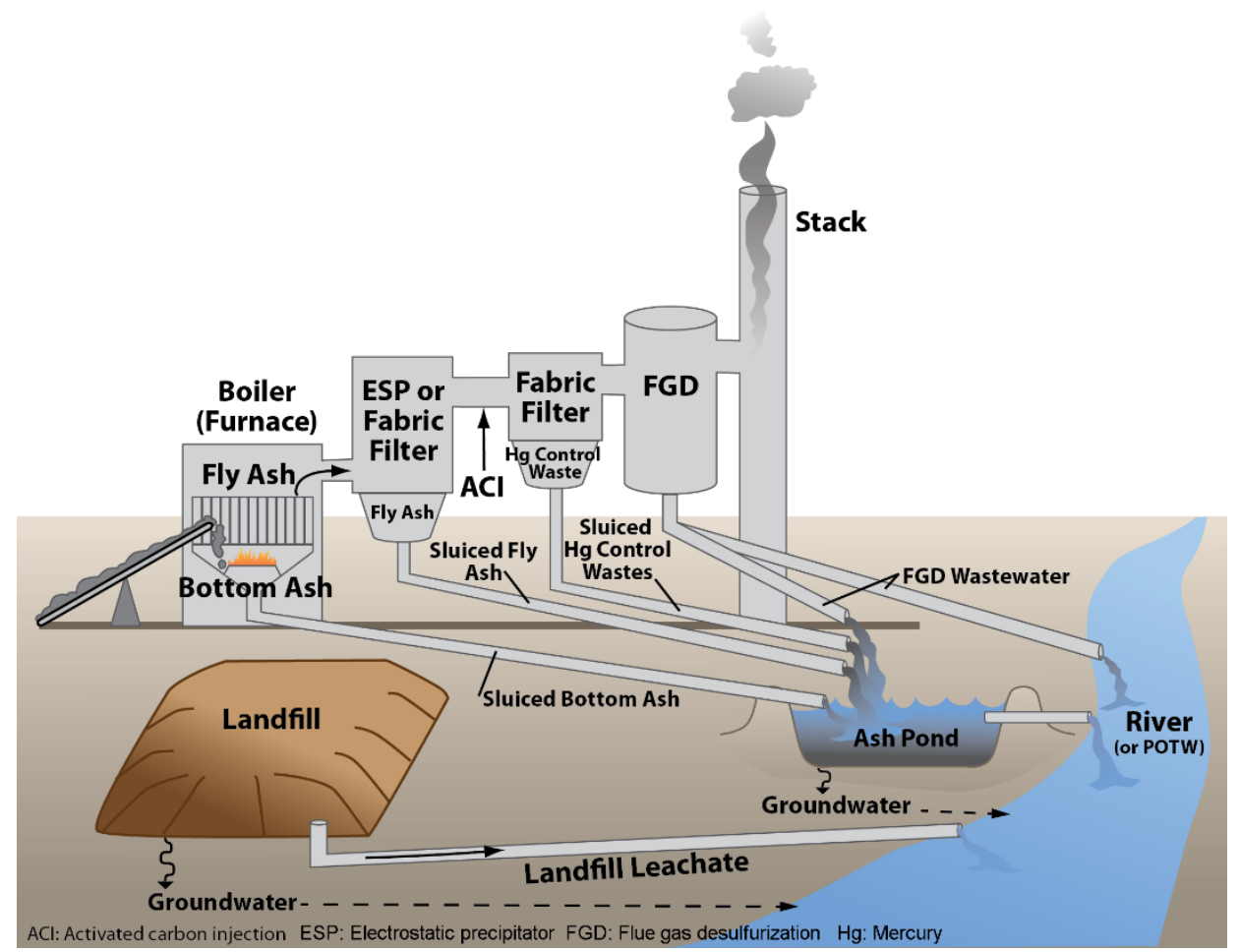

Another waste stream from coal plants is metal cleaning waste, which refers to any wastewater that is produced due to cleaning a metal process equipment. This may come from cleaning equipment that includes boiler tubes, boiler firesides, and air preheaters. Since boilers are constructed of metals, typically copper, iron, nickel, and zinc, these are the largest constituents of cleaning wastes from boilers. Metal cleaning wastes may also include sulfur compounds and chemicals that remove scale and corrosion products. However, unlike most coal plant wastes, metal cleaning wastes are typically generated infrequently, perhaps once every 10 years. Since these wastes have high 
pollutant concentrations and are generated so infrequently, plants may have separate wastewater handling processes for metal cleaning wastes. These wastes are usually sent to an ash pond or other surface impoundment. ${ }^{125}$

Another waste stream is created from coal pile runoff. This occurs when runoff caused by rainwater and melting snow comes into contact with coal piles. Coal plants often store enough coal to last 30 days in an outdoor coal pile. The amount of runoff is dependent on the quantity of precipitation, the capacity of the plant, the physical location and layout of the pile, and the extent to which water permeates the ground underneath the pile. Coal pile runoff is usually acidic due to the oxidation of iron sulfide and ferric hydroxide, and may also contain high concentrations of copper, iron, aluminum, nickel, and other pollutants. Coal pile runoff wastewaters are often directed to a holding pond with storm water runoff from other areas near the coal pile.126

Pollutants from coal plants can cause significant health and environmental challenges. These include human cancer risks, decreased IQ levels for children, and fish and wildlife deformities and negative reproductive effects. Many of these pollutants remain in the environment for years. ${ }^{127}$ Due to their proximity to discharges and relatively high consumption of fish, some low-income and minority communities are more vulnerable to exposure from pollutants found in coal plant discharges. ${ }^{128}$ An EPA study found the population living within three miles of a coal plant was $48 \%$ minority. ${ }^{129}$ This was $12 \%$ higher than the national average. ${ }^{130}$ Additionally, the $31 \%$ of the population living within three miles of a coal plant was under the poverty level, $4 \%$ higher than the national average. ${ }^{131}$

\section{$2.3 \quad$ TRENDS IN COAL RETIREMENTS}

The trajectory of recent closures of coal plants due to more stringent environmental regulation and increased competition from natural gas plants mirrors Navigant's estimates of coal plant decommissioning revenue in the North American market between 2013 and 2020.132 In combination with newly regulated coal ash handling, the planned wave of coal plant retirements revenue from decommissioning will create a multi-billion dollars market for demolition businesses; engineering; procurement and construction (EPC) companies; and environmental remediation firms (Figure 2.4).133 134 The estimate considered conversion of coal plants to other fuel sources, closure, and demolition, among other options. ${ }^{135}$

Already, the U.S. coal production industry is shrinking. SNL Financial estimates that only three of America's leading coal companies are currently demonstrating positive cash flows. ${ }^{136}$ McKinsey and Company estimates that the coal industry as a whole is bankrupt, lacking $\$ 45$ billion to fund its debts and liabilities. ${ }^{137}$ While most financial analysts assume that coal will be a major fuel for electricity generation for many years or decades to come, the U.S. coal industry is likely to see a major restructuring. 
Figure 2.4 Coal Plant Decommissioning Revenue in North America: 2013 - 2020138 139 ix

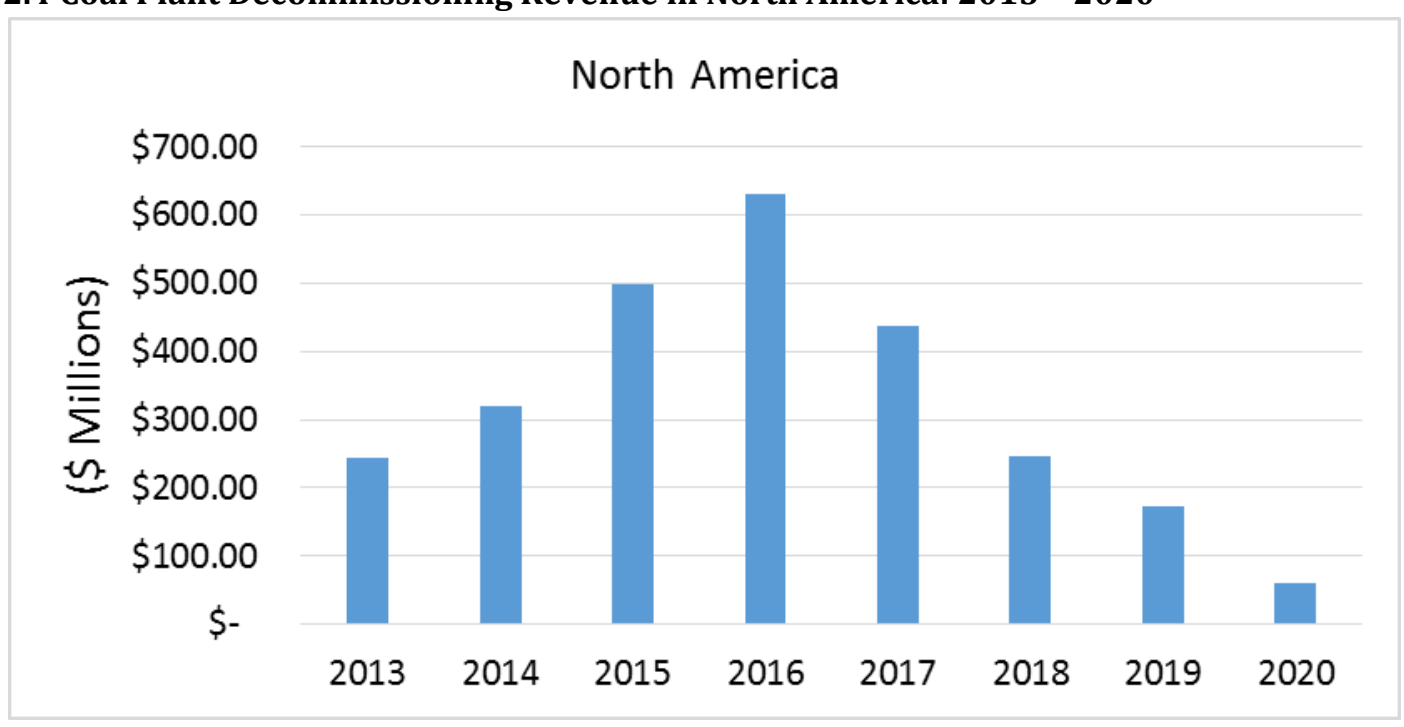

\subsection{DECOMMISSIONING}

Decommissioning, also called plant retirement, occurs when a plant is deemed inoperable.

\subsubsection{Waste Streams, Regulations, and Costs}

As coal plants approach retirement and before decommissioning begins, the plant's coal inventory needs to be burned, shipped to another coal plant, or sold for other uses. The remaining inventory to be managed is scrap metal, coal ash, scrubber slurries, and the common materials that accompany power generation as described in Table 2.1. Burns \& McDonnell characterized one plant they decommissioned as having a large amount of high-value scrap metal that defrayed its project costs by several million dollars. ${ }^{140}$ According to Martin and Mackinnon, the value of the scrap metal from the plant on the open market will, in some cases, fully offset the cost of demolition. Going forward, however, there is likely to be a glut of scrap supply, which will make such opportunities more difficult. ${ }^{141}$

While coal-fired plants store large quantities of many chemicals, the chemicals themselves do not produce many hazardous wastes. However, after canceling all orders for new chemicals, unused chemicals should be properly disposed of or sold for use at other plants. The removal of asbestos containing material (ACM) will be costly and require careful planning. The process starts by assessing whether on-site or off-site landfills are used. However, ACMs may not always be discovered until after the decommission process has begun. ${ }^{142}$ ACM's will be described more in common materials chapter.

According to Martin and Mackinnon, environmental remediation will be the most expensive phase of many decommissioning projects. ${ }^{143}$ In particular, disposing of coal ash, typically stored in ponds onsite, is challenging and costly. ${ }^{144}$ Project managers can dispose of coal ash off-site or import fill-

ix This only includes announced retirements as of 2013 
materials for inplace closure. Other options that may address coal ash include capping, consolidating into a landfill, converting to wetlands, or reusing for beneficial applications. ${ }^{145}$ Table 2.3 was created based on engineering estimates from sample plants that are representative of plants that utilize surface impoundments and considers the cost of closing these surface impoundments. The table shows costs (in \$2009) over a 20-year period using a 3\% discount rate. Capital costs were calculated by estimating the cost of converting wet fly and bottom ash handling systems to dry ones, and installation costs of replacing surface impoundments with waste water treatment capacity. Operating costs refer to the costs associated with operation, management, and maintenance costs of waste streams and replacing surface impoundments with waste water treatment plants. Two costs are listed for wastewater treatment plants (WWTP), capital cost and operating cost, that are dependent on the presence of FGD. The WWTP capital cost for a facility with a FGD is $\$ 120$ million, while a facility without a FGD costs only $\$ 80$ million. The difference in cost is because FGD systems remove constituents that are costlier to treat before discharge. Similarly, the operating cost for a facility without a FGD ( $\$ 3$ million) is less expensive than a facility with a FGD ( $\$ 4.5$ million). Based on Table 2.3, the annualized costs of phasing out coal ash ponds over a 20year period with a $3 \%$ discount rate are about $\$ 2.5$ billion, or 6.3 million per unit. 146 
Table 2.3 Costs of Phasing Out Ash Ponds at American Fossil Fuel Power Generation Facilities*147

\begin{tabular}{|c|c|c|c|}
\hline Cost Component & Affected Units & Unit Cost & Present Value Cost \\
\hline Bottom Ash Conversion & $\begin{array}{c}397 \text { Affected Generating } \\
\text { Units** }\end{array}$ & $\$ 30$ million per unit & $\$ 10$ billion \\
\hline Fly Ash Conversion & $15,000,000$ tons & $\$ 200$ per ton & $\$ 2.5$ billion \\
\hline $\begin{array}{l}\text { Dry Materials } \\
\text { Management }\end{array}$ & 20.6 million tons & $\$ 2$ per ton & $\$ 400$ million \\
\hline $\begin{array}{l}\text { Accelerated Pond } \\
\text { Closure }\end{array}$ & $\begin{array}{l}11.6 \text { years of unused } \\
\text { capacity foregone }\end{array}$ & $\$ 280$ million & $\$ 2.5$ billion \\
\hline WWTP*** Capital Cost & 155 facilities & $\begin{array}{l}\$ 80 \text { million or } \$ 120 \\
\text { million*** }\end{array}$ & $\$ 14.5$ billion \\
\hline WWTP Operating Cost & 155 facilities & $\begin{array}{l}\$ 3 \text { million or } \$ 4.5 \\
\text { million }\end{array}$ & $\$ 5.2$ billion \\
\hline WWTP Pond Capacity & 155 facilities & $\$ 30$ million & $\$ 4$ billion \\
\hline $\begin{array}{l}\text { Additional Land } \\
\text { Acquisition Cost }\end{array}$ & N.A. & & Unquantified \\
\hline $\begin{array}{c}\text { At-Risk Generation } \\
\text { Capacity }\end{array}$ & 397 units & & Unquantified \\
\hline Total NPV Cost & & & \$39 billion \\
\hline Annualized Cost & & & $\$ 2.5$ billion per year \\
\hline
\end{tabular}

${ }^{*}$ Calculations based on a $3 \%$ discount rate.

**EIA Form 767 Database lists 128 facilities that manage bottom ash in surface impoundments. At these facilities are 397 coal-fired boilers

*** WWTP is an acronym for wastewater treatment plant

**** The cost is dependent on the presence of a scrubber. Facilities with scrubbers (FGD) will require more advanced units that are larger and more expensive ( $\$ 120$ million) than facilities without scrubbers ( $\$ 80$ million).

These cost estimates of $\$ 80$ - $\$ 120$ million for converting wet fly and bottom ash handling systems to dry ones at a typical U.S. coal plant are consistent with a TVA estimate. In 2009, TVA estimated that the cost to convert its wet storage coal byproduct facilities to dry storage facilities, at all of its 11 coal-fired plants, would be $\$ 1.5$ to $\$ 2$ billion. ${ }^{148}$ 


\subsubsection{Decommissioning Options}

\subsubsection{Minimal Demolition and Idling}

Plant owners have the option to idle a coal-powered generating unit, at the end of its planned operational life. To do this, the plant owner must ensure that the unit meets the standards necessary for compliance with environmental regulations. This can be done through ceasing shipment of chemicals to the site required for daily plant operation, and ensuring access to the plant is restricted to the public. Another strategy that project managers can employ is meeting compliance standards, but also conducting minimal demolition of the plant. ${ }^{149}$

The value of these options is the flexibility they provide to plant operators as a hedge against the possibility of rising natural gas prices in the future.

\subsubsection{Full Decommissioning}

Plant retirement, also called full decommissioning, occurs when a plant is deemed inoperable and needs to be shut down permanently. Full decommissioning involves demolishing all structures on the premises and dismantling all facility equipment. ${ }^{150}$ The waste streams, regulations, and costs of full decommissioning are described in Section 2.4.1.

Before full decommissioning can begin, inventories are assessed, environmental impacts are considered, and safety issues are evaluated. Planning the decommissioning process includes identification of who will be responsible for completing the tasks of decommissioning. One option is for the plant owner to oversee and undertake all tasks related to cleaning, decommission, and demolition. Conversely, the utility company can oversee the project, but contract out the decommissioning objectives. This can be done through either one contractor or multiple contractors. A final choice is to contract for a turn-key operation so the plant is in acceptable condition for the next owner. By the end of the planning process, the project manager should be able to estimate the activities that need to be accomplished and a project schedule.

It is likely that most decommissioned sites will achieve brownfield status. ${ }^{151}$ The EPA defines a brownfield as, "an abandoned, idled, or under-used industrial or commercial facilities where expansion or redevelopment is complicated by real or perceived environmental contamination." Coal plants often fall in this category because of both the real and perceived fear of contamination. ${ }^{152} \mathrm{An}$ alternative is to repurpose the site.

\subsubsection{Site Repurposing}

Proposals have called for diversifying career opportunities in coal communities in an effort to revitalize their economic fortunes. Industrial re-use can be a win-win for communities and the plant owner: a redevelopment authority or government program may provide the plant owners with financial assistance for the decommissioning and repurposing process, and the community gains the benefits of a productive site for subsequent use by job-generating enterprises. Residential reuse would appear to be a costlier and difficult transition compared to industrial re-use for a coal 
plant site, but if a site has high locational value, it may be feasible to transition it to a new mixed-use community development. Examples of industrial and mixed-use repurposing are emerging.

In Austin, the art deco Seaholm Power Plant was decommissioned in 1989. Since the 1990s, the former coal plant has become the host of concerts and other special events. Now, plans are underway to add a condominium/hotel, office space, restaurants, and retail space to the existing buildings and land the power plant once occupied. ${ }^{153}$ Similar diversification is occurring at a plant in northeastern Alabama. The TVA Widows Creek Fossil Plant recently announced land made available from retiring coal units in Northern Alabama will be utilized by a Google data center.

In order for a site to be re-used in the future, it must be cleaned to comply with additional environmental regulations. EPA maintains different standards for cleaning of a site after closing dependent on whether the new property will be re-used for commercial, industrial, or residential purposes. Knowing how the site will be used in the future can be pivotal in determining cost-cutting measures. In order for the site to be repurposed, the coal yards need to be cleaned and exterior systems, such as coal handling equipment, need to be moved from the facility site. All coal residue present in the soil of the coal yard should be moved to an on-site ash landfill or surface impoundment or off-site permitted facility. ${ }^{154}$ Should the soil need excavation, the coal yard requires contouring for runoff of storm-water. Cleanup of the coal yard will typically require development and adherence to a National Pollution Discharge Elimination System (NPDES) Stormwater Pollution Control Plan. ${ }^{\mathrm{x}}$

Additionally, power system components must be taken out of the plant. Permits for ash ponds must also be amended to either be reused possibly as solid waste landfills or closed. ${ }^{155}$

\subsection{CHAPTER CONCLUSIONS}

The two largest forms of solid waste from coal-fired generation are coal ash (from the combustion of coal), and "scrubber" slurry (from environmental controls at the plant). Coal ash is the second most abundant waste material in the United States, after household waste. Both of these solid wastes can impact local ecosystems when unplanned releases occur. The composition and quantity of this solid waste depends on the type of coal burned, the power conversion technology used, and the addition of environmental controls. These factors, in turn, influence the ability to recycle or put the waste to productive reuse.

Between 2004 and 2014, the mass of fly ash and bottom ash produced from electricity generation has decreased as a result of reduced electricity generation at coal power plants. ${ }^{156}$ Over the same decade, the percentage of ash re-used in beneficial applications increased from 40 to $46 \%$ (for fly ash) and from 47 to $49 \%$ (for bottom ash). ${ }^{157}$ It costs approximately $\$ 80-\$ 120$ million to convert wet fly and bottom ash handling systems to dry ones at a typical coal plant. .158

With the increase in recent and forecast coal plant retirements, the nation is seeing an increase in solid waste from decommissioning. Full plant decommissioning to brownfield status is costly, and

x $\underline{\text { htps: //www.epa.gov/npdes }}$ 
conversion for re-use requires additional investments. It has been estimated that the planned wave of coal plant retirements revenue from decommissioning will create a multi-billion dollars' market for demolition businesses, engineering; procurement and construction (EPC) companies; and environmental remediation firms. ${ }^{159}$ Decommissioning of coal plants in 2015, for instance, was estimated to cost approximately $\$ 500$ million. ${ }^{160}$ Examples of industrial and mixed-use repurposing of retired coal plants are emerging.

Most of the coal plants that are now being retired did not have decommissioning plans in place either prior to plant construction or during a majority of their operational lives. There is no model approach in place in the United States for preparing retirements plans for coal-fired power plants. 


\section{NATURAL GAS AND PETROLEUM}

The solid wastes produced by the operation and decommissioning of natural gas and petroleum electricity generation are discussed together in this chapter because they have some common attributes as fossil fuels. At the same time, their generation technologies are distinct, as is the chemistry of their fuels.

Electricity generation from natural gas has grown rapidly in the United States over the past decade. By 2015 , natural gas was used to generate $33 \%$ of the nation's electricity, equal to the electricity generated by coal. Petroleum, in contrast, is responsible for only 1\%. ${ }^{\mathbf{1 6 1}}$ Before the Arab oil embargo in 1973-74, oil was a major source of electricity generation in the United States, but its contribution over time has decreased substantially, and few new oil plants have been built in recent years. As a result, this chapter principally focuses on solid waste from natural gas power plants.

\subsection{BASIC OVERVIEW OF TECHNOLOGY}

The two main technologies for natural gas generation are single cycle combustion turbines (CTs) and combined cycle combustion turbines (CCs) that use exhaust heat to run a secondary steam generator. Combined heat and power (CHP) systems cover another family of electricity generation options for natural gas (and other fuels) that offer high levels of energy efficiency by recovering and productively using waste heat. Despite its high penetration in Japan and many European countries, it is still a "niche" technology in the United States. Fuel cells are emerging technology that typically use hydrogen reformed from natural gas to generate electricity. Since CHP and fuel cell systems do not contribute significantly to U.S. electricity generation, we will not discuss their solid waste streams.

Electricity generation from diesel principally uses CTs, while oil-fired plants use steam turbines. Petroleum is primarily used as a last resort for extreme peaking generation, partly because it produces substantial amounts of air pollution including $\mathrm{NO}_{x}, \mathrm{SO}_{2}, \mathrm{PM}_{2.5}$ and $\mathrm{PM}_{10} .{ }^{162}$ In 2011, petroleum electricity generation caused monetized pollution costs that are about one third lower than coal electricity generation per MWh, but overall generation is very small and thus petroleum power plants are responsible for only about $3 \%$ of total power generation monetized costs of air pollution. In contrast, natural gas generation produces almost no $\mathrm{SO}_{2}$ emissions and less $\mathrm{NO}_{\mathrm{x}}, \mathrm{PM}_{2.5}$ and $\mathrm{PM}_{10 .}$. per $\mathrm{MWh}$ of electricity generation than either oil or coal. Air pollution from natural gas power generation in 2011 caused monetized costs equal to about $\$ 1$ billion per year, corresponding to about $1 \%$ - $2 \%$ of total monetized costs of air pollution. ${ }^{163}$

\subsubsection{Natural Gas Combustion Turbines}

Natural gas CTs are based on jet airplane engine designs. Air is first compressed by the turbine and fed into the combustion chamber. Natural gas is then injected into the combustion chamber and burned at roughly $2,000^{\circ} \mathrm{F}$ to produce a high temperature and pressure gas stream. This gas stream is then expanded through airfoil blades that spin a turbine to produce electricity (Figure 3.1). Single cycle turbines typically operate at efficiencies between 20 and 35\%, but CTs can ramp up quickly to 
provide peaking resources; ${ }^{164}$ CTs are therefore used principally to meet peak demand for electricity and can command higher prices per kWh than baseload power.

\section{Figure 3.1 Natural Gas Combustion Turbine ${ }^{165}$}

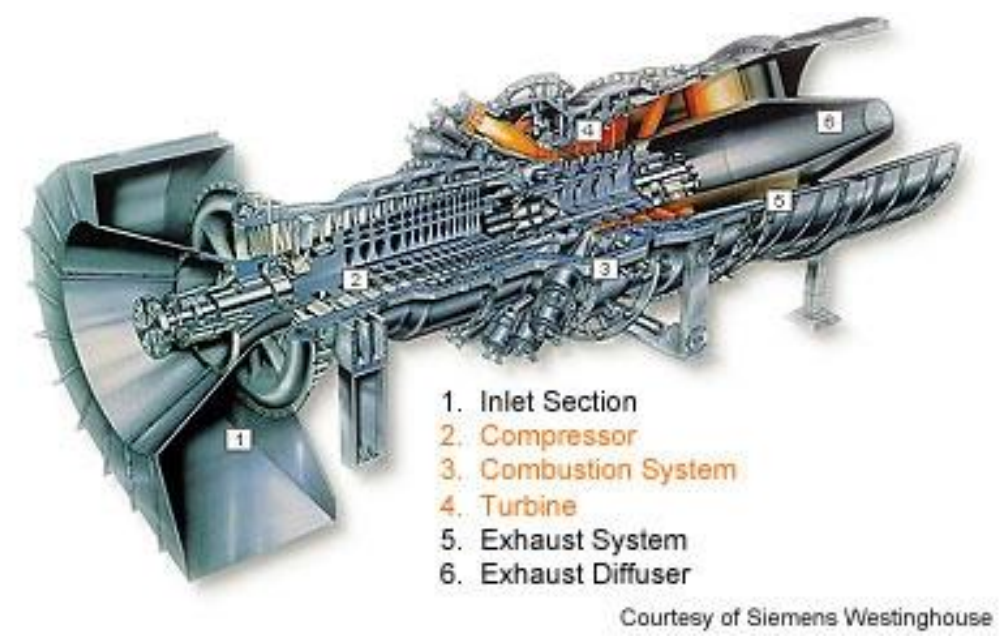

\subsubsection{Natural Gas Combined Cycle Generators}

Natural gas combined cycle (CC) turbines operate similarly, except that hot exhaust gas from the combustion turbine is used to boil water and make steam that powers a secondary steam turbine. They are more efficient than CTs because they re-use waste heat. However, CCs take longer to reach their efficiencies (from a few minutes to about three hours depending on the design and the time that the plant has been shut down ${ }^{166}$ ) due to the time it takes to make steam. Therefore, if the peak is only two hours, then the added value of the steam cycle is lost. Like CTs, they are able to ramp up and down more quickly than nuclear and coal plants. In addition to their relatively high efficiency (about $50 \%{ }^{167}$ ), they are increasingly preferred for intermediate load operation.

\section{Figure 3.2 Combined Cycle Generator}

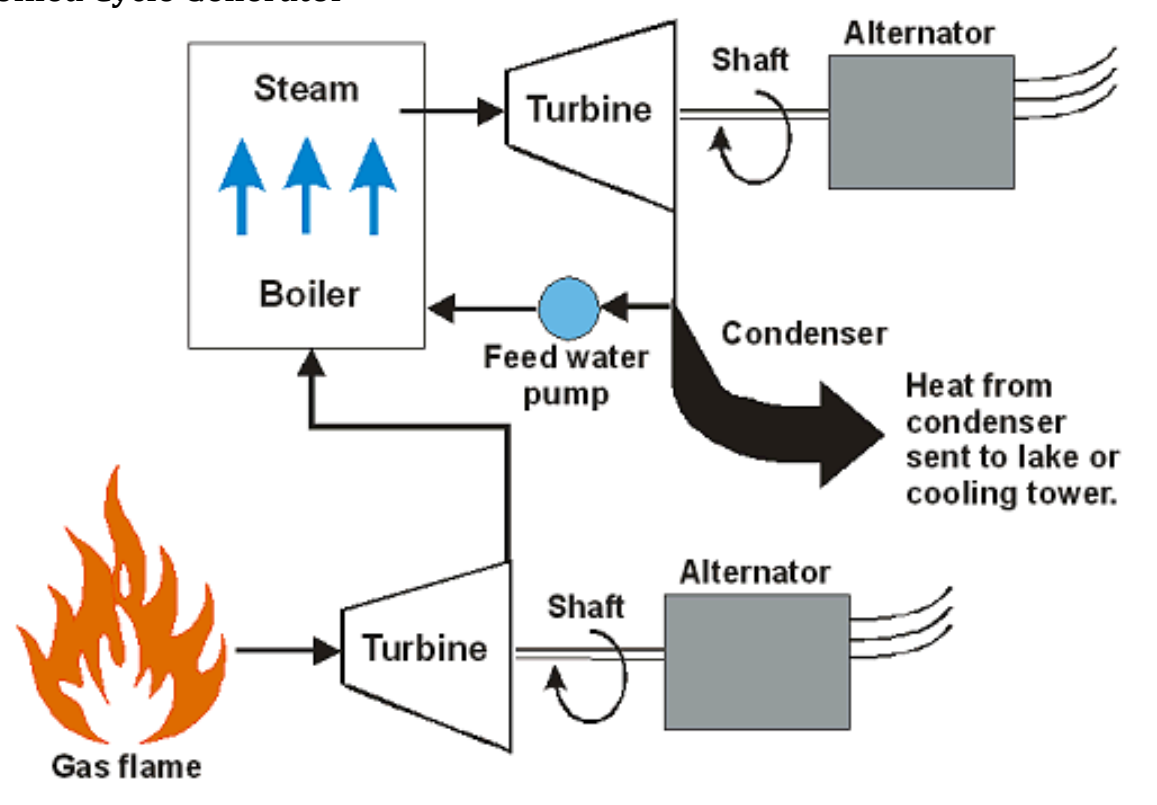




\subsection{WASTE GENERATION AND MANAGEMENT}

Unlike coal plants and nuclear reactors gas and oil-fired plants do not generate combustion ash or nuclear waste. The unique solid waste concerns for gas- and oil-fired plants are the byproducts from emission controls. However, considering the low adoption rate of these emission controls for gas- and oil-plants, the solid waste from electricity generation is not considerable.

Because oil- and gas-plants produce $\mathrm{CO}_{2}$ and other air pollutants, they also generate solid waste when they use environmental controls for air pollution mitigation. These solid wastes are similar to the waste generated by environmental controls placed on the stacks of coal plants, especially for most post-combustion removal technology. For example, selective catalytic reduction, one process for the post-combustion removal of $\mathrm{NO}_{\mathrm{x}}$, has been applied for treatment of flue gases from a variety of emission sources, including natural gas- and oil-fired turbines, as well as coal-fired power plants. ${ }^{168}$ These technologies generate a similarly small volume of pollution control waste when applied to oil and gas as when applied to power plants; they therefore call for similar waste management processes. Most of the flue-gas desulfurization technologies used in coal are also applicable to oil- and gas-fired plants. 169

In 2014, flue-gas desulfurization controls at oil- and gas-plants used dry/wet scrubbers similar to coal plants: spray dry scrubbers accounted for $45 \%$ of the nameplate capacity of all plants with flue-gas desulfurization controls, dry sorbent injections accounted for $13 \%$, and wet scrubbers accounted for $12 \% .{ }^{170}$

Emission controls for particulate matter from oil and gas plants are also similar to those used in coal plants. In 2014, 49\% of the nameplate capacity of all units with flue-gas particulate matter controls were done through electrostatic precipitator and $21 \%$ through fabric filters. ${ }^{171}$

In practice, few natural gas and oil plants have these emission control technologies. In 2014, only $2.4 \%(1,134 \mathrm{MW})$ of total nameplate capacity of oil plants and 3.9\% $(19,284 \mathrm{MW})$ of natural gas plants had flue-gas desulfurization controls. ${ }^{172}$ The use of particulate matter controls is similarly infrequent. Only $7.4 \%$ (3,452 MW) of the nameplate capacity of all oil plants in 2014 and $13.4 \%$ $(66,386 \mathrm{MW})$ of the nameplate capacity of all natural gas plants in 2014 had particulate matter controls. ${ }^{8}$ The lack of controls is a reflection of the fact that emissions of criteria pollutants from oil and natural gas plants are substantially smaller than from coal plants. A 2010 report by the National Research Council estimated that natural gas plants emit 0.05 pounds of $\mathrm{SO}_{2}, 2.3$ pounds of $\mathrm{NO}_{\mathrm{x}}, 0.11$ pounds of $\mathrm{PM}_{2.5}$, and 0.12 pounds of $\mathrm{PM}_{10}$ per $\mathrm{MWh}$ while coal plants emits 12 pounds of $\mathrm{SO}_{2}, 4.1$ pounds of $\mathrm{NO}_{\mathrm{x}}, 0.59$ pounds of $\mathrm{PM}_{2.5}$, and 0.72 pounds of $\mathrm{PM}_{10}$ per $\mathrm{MWh}$ respectively (Table 3.1). ${ }^{173}$ 
Table 3.1. Pounds of Criteria Emissions per MWh by Natural Gas Power Plants ${ }^{174}$

\begin{tabular}{lcc}
\hline & Mean & Standard deviation \\
\hline $\mathbf{S O}_{2}$ & 0.05 & 0.2 \\
NOx $_{\mathbf{x}}$ & 2.3 & 9 \\
$\mathbf{P M}_{2.5}$ & 0.11 & 0.39 \\
$\mathbf{P M}_{10}$ & 0.12 & 0.39 \\
\hline
\end{tabular}

No national historical summary reports or publicly available data could be found to analyze how much solid waste has been generated by environmental controls at oil- and gas-fired plants.

\subsection{OPTIONS FOR DECOMMISSIONING OF GAS AND PETROLEUM POWER PLANTS}

Preparation efforts for decommissioning oil and gas power plants must begin years in advance. Similar to the decommissioning process of other plants, the site must be secured, cleaned, and maintained according to environmental regulations. ${ }^{175}$ Planning usually begins by reviewing the current conditions of the plant and assessing the risks and hazards of decommissioning the plant. This includes the condition and security of buildings, above ground storage tanks, cooling towers, fire suppression systems, and river water inlets. Elements of the assessment are based on conducting a hazardous materials survey, a site underground survey, and a topographical survey. The plant manager then develops a decommissioning plan with an emphasis placed on the environmental and legal liability. ${ }^{176}$

There are three methods for decommissioning an oil or gas plant, considering the conditions of the plants and the total budget.177

- The first option that the utility can employ is "cold closure." This occurs when the plant becomes inoperable because the plant owner suspends power plant service. The term was coined because systems that may not function due to freezing (such as boiler systems and fuel tanks) are decommissioned, while materials regularly used in plant operations are transported from the premises. The infrastructure of power plants remains intact and the generation can be easily resumed by shipping in materials required.

- The second option is "selective demolition." Under this method, demolition occurs in phases. Fuel systems are defueled and tanks are cleaned, utilities are suspended, equipment is re-sold or salvaged, and the dangers posed from hazardous materials are mitigated. In this option, part of the infrastructure is removed and the remaining infrastructure will not be used for electricity generation in the future.

- The final method is "total demolition." In this form of decommissioning, the entire plant is razed and all systems demolished.

These three methods will generate different quantities of solid waste. The first will generate a relatively small amount of solid waste compared to the second and third, because it does not require demolishing the infrastructure. However, in the latter two options, the decommissioning processes commences with shutting down equipment including auxiliary boilers, preheat 
generator, and turbine units. Ultimately in both of these options, the cooling tower is emptied, dismantled, and taken from the site, while it is not removed under "cold closure."178

These decommissioning processes also generate solid waste from the treatment of on-site tanks or pipes. Tank removal consists of cleaning the interior and exterior, leakage prevention, tank dismantlement on-site, transport off-site and recycling as scrap metal. Alternatively, tanks may be subjected to in-place tank decommissioning. After inspection, the residual heating oil and fluids will be pumped from the tank, and then the tank is filled with an inert solid material such as a lean concrete mix, foam, slurry, or sand. The choice between the two options is made based on the physical condition of the tank, and the surrounding soil environment. However, the first option is often favored because the removal avoids the relatively high cost of future leakage and soil contamination, which are possible risks of in-place tank decommissioning. ${ }^{179}$

The common approach for crude oil and natural gas pipelines are in-place decommissioning, which requires less demolition work and is considered to be more environmentally friendly and less costly. ${ }^{180}$ Abandonment of crude oil and natural gas pipelines are regulated by the Pipeline and Hazardous Materials Safety Administration, a U.S. Department of Transportation agency, under Code of Federal Regulations Title 49 Subchapter D Part 192 and 195.181 The rule requires that abandoned oil and gas pipelines first be "disconnected from all sources and supplies" of gas and oil and then be cleaned using pressure-enhanced pipeline draining. ${ }^{15}$ Usually, part of the pipeline will be removed to allow modifications and the remaining pipe is filled with grout or other inert materials. ${ }^{15}$ Surfaces are then restored usually with a backfill process using existing material that is not contaminated including gravel, sand, silt, clay, and soil.

\subsection{DECOMMISSIONING: WASTE STREAMS, REGULATIONS, AND COSTS}

The decommissioning of gas and oil power plants creates a variety of wastes that can be divided into distinct categories based on their constituents, as follows: construction and demolition (C\&D) waste; general refuse; and chemical waste. ${ }^{182} \mathrm{C} \& \mathrm{D}$ waste, general refuse, and some of the chemical waste (including lead-acid batteries for turbine start-up and other electronics) are not unique to oil and gas plants and are therefore covered in Chapter 6, which focuses on common wastes. Chemical waste that is particular to oil and gas plants includes naturally-occurred radioactive materials, which are relatively unique to oil and gas plants.

During the oil and gas combustion process, because naturally-occurred radioisotopes (NORM) are not volatile, burning away the carbon leads to higher levels of radioactive waste in scale, sludge and scrapings of the generator, tanks and pipelines. ${ }^{183}$. Radioactive material can also form a thin film on the interior surfaces of gas processing equipment and vessels. The targeted possible radioactive elements include primarily uranium and thorium. The level of radioactivity depends on the source of the fossil fuels as well as the concentration effect of burning. ${ }^{184}$

Currently no federal regulations exist that specifically address the handling and disposal of NORM wastes. However, several oil-producing states (Texas, Louisiana, New Mexico, North Dakota, and Mississippi) have enacted specific NORM regulations. ${ }^{185}$ While these regulations focus on oil and gas production sites, they are also applicable to decommissioning NORM contaminated solid waste. For 
example, according to Texas Environmental Protection, Subchapter F, NORM-contaminated equipment must be decontaminated if it is to be released for unrestricted use (e.g., used for some purpose other than for oil and gas activities). Texas does not allow the burial of NORMcontaminated equipment, but requires disposal of oil and gas NORM waste at a licensed facility by a state NORM licensee. ${ }^{186}$

Unfortunately, it appears that no comprehensive studies have examined the disposal of NORMs during the decommissioning of gas- and oil-fired plants. There are no consensus disposal mechanisms or reliable cost estimations. It remains unclear how NORMs from decommissioning should be treated or disposed.

There is no comprehensive public information, utility reports, or academic studies about the cost of different decommissioning options. Few reports or articles cover the detailed cost of oil- and gasfired generation decommissioning, let alone specific to solid waste disposal cost associated with this process. For example, the National Energy Technology Laboratory reported that for NGCC plants, switchyard/trunkline system and decommissioning are together considered only as capital costs and are equal to $\$ 0.0016 / \mathrm{kWh}$, which does not include tank or other waste disposal. ${ }^{187} \mathrm{In}$ other studies, it was often assumed that the decommissioning energy use and emissions were $10 \%$ of commissioning costs. ${ }^{188}$

\subsection{CHAPTER CONCLUSIONS}

During their operation, the only solid wastes associated with the generation of electricity from oiland gas-fired plants are emission control wastes. However, these wastes are relatively small in magnitude because emission controls on gas- and oil-fired plants are relatively uncommon. In 2014, only $2.4 \%$ of total nameplate capacity of oil plants and $3.9 \%$ of natural gas plants had flue-gas desulfurization controls. ${ }^{189}$ The use of particulate matter controls is similarly infrequent. No national historical summary reports or publicly available data could be found to analyze how much solid waste has been generated by environmental controls at these oil- and gas-fired plants.

As to the decommissioning process, other than general solid waste that is specific to all types of plants, chemical solid waste needs special attention. These wastes include the contaminated scale, sludge and scrapings in the part of the generator, tanks, and pipelines. Thus, the focus of decommissioning oil- and gas-fired generation is to safely dispose of chemically contaminated equipment and parts. The disposal methods include removal and in-place decommissioning. Depending on the situation of different equipment and parts, the detailed procedures can be variable. However, there is a lack of comprehensive studies: the chemical solid waste is not fully understood and the waste disposal plans are often not specific to the decommissioning process of power plants.

Few reports or articles cover the detailed cost of oil- and gas-fired generation decommissioning. Information on the cost of different decommissioning options is limited. Further, data on specific solid waste disposal costs associated with decommissioning is largely nonexistent. 
Most of the natural gas and oil plants that are now being retired did not have decommissioning plans in place either prior to plant construction or during a majority of their operational lives. There is no model approach in place in the United States for preparing retirements plans for such fossil-fueled power plants. 


\section{NUCLEAR}

\subsection{BASIC OVERVIEW OF TECHNOLOGY}

Nuclear power plants use enriched uranium for fuel. This fuel creates a fission reaction that produces heat to make steam for electricity generation. In the fission reaction, uranium atoms are split inside a nuclear reactor. At the 99 commercial nuclear reactors in the United States, two types of power reactors are used. Pressurized water reactors (PWRs), utilized at 65 reactors, use two separate systems to produce electricity. Water is heated in the reactor, but not allowed to boil due to the pressurized system. This water is then run through a heat exchanger, which heats water in a second system to produce steam that drives a turbine. Conversely, boiling water reactors (BWRs), utilized at 34 reactors, contain only one process system; water in the reactor is heated to form steam, which drives a turbine. ${ }^{190}$

Since nuclear power plants are historically expensive to start and stop, cannot easily ramp up and down, and are uneconomical to run at less than full capacity, they are only used as base load generators. Although, research is underway to improve the flexibility of these plants. ${ }^{191}$ Nuclear energy is one of the few energy resources that can operate without emitting pollutants including carbon dioxide and sulfur dioxide. As a result, nuclear power is essentially a carbon-free energy source. ${ }^{192}$ Its lifecycle GHG emissions, for instance, are approximately 29 tonnes $\mathrm{CO}_{2}$ e per GWh, which mainly comes from the construction of the plant. ${ }^{193}$ However, its nuclear waste requires careful handling.

\subsection{WASTE FROM GENERATION AND ITS MANAGEMENT}

Although fuel rods lose the ability over time to produce enough heat to sustain power production, they remain radioactive. Until used fuel radiation decays to background levels, it must be safely managed. ${ }^{194}$ The nuclear industry produces about 2,200 metric tons of used fuel annually. $195 \mathrm{xi}$ Nearly 72,000 metric tons of nuclear waste is currently managed at 75 sites in the United States (Figure 4.1).196 This waste is either stored on site in cooling ponds (69\%) or in temporary dry casks (31\%).197 There is currently no centralized storage facility or repository for commercial nuclear waste in the United States. While other countries recycle spent fuel rods, this process is not currently used due to economic and security concerns in the United States. ${ }^{198}$ Used fuel is transferred to cooling ponds immediately after being removed from a reactor core. These nearby cooling ponds can store thousands of cubic feet of water. Following decades of use, the ponds have begun to reach their capacity. As a result, fuel is often moved to dry casks following an approximate five-year cooling period. ${ }^{199}$

Dry casks are concrete or metal cylinders with walls that are on average about twenty inches thick, approximately sixteen feet in length and eight feet in diameter. They are also designed to withstand extreme natural disasters. The Nuclear Regulatory Commission (NRC) has approved over 20 different dry cask designs and regularly tests potential future designs. Casks are currently granted 20-year certificates of compliance. However, this license may be renewed for "extended operation"

xi http://www.gao.gov/key issues/disposal of highlevel nuclear waste/issue summary 
following an evaluation. ${ }^{200}$ To be considered for renewal, the certificate holder must submit a request to NRC with information describing (1) the capability of the cask design to meet technical requirements and (2) the capability of loaded casks to continue to meet technical requirements for another 20 years. The NRC then determines whether to renew the certificate in accordance with NUREG-1927, "Standard Review Plan for Renewal of Spent Fuel Dry Cask Storage System Licenses and Certificates of Compliance."xii

Figure 4.1 Vertical Casks on a Concrete Pad Being Monitored ${ }^{x i i}$

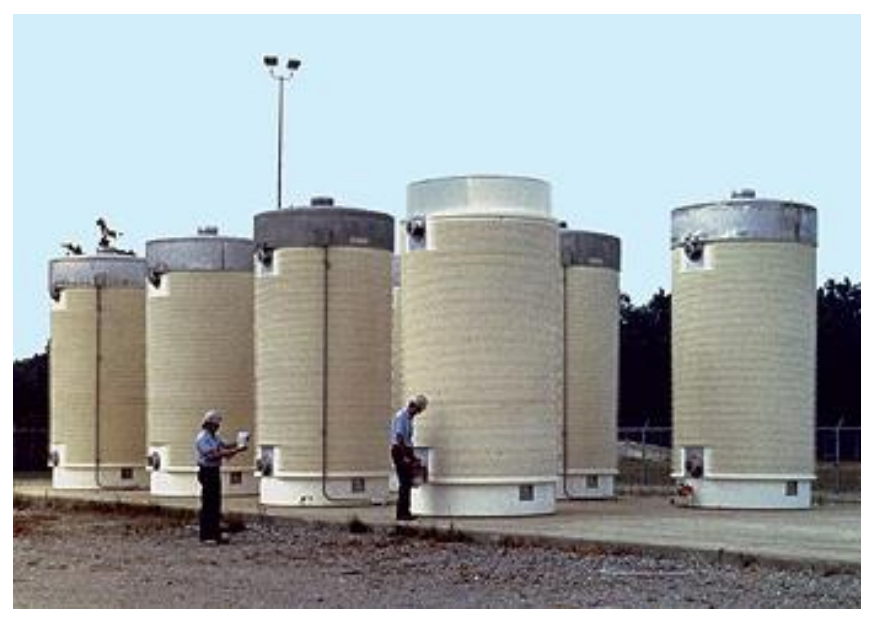

Following fission, the atomic nucleus emits radiation as particles that also results in low-level radioactive gases and liquid wastes. ${ }^{201}$ This radioactive waste is stored in on-site tanks until it decays to a level so that it can be treated or released. ${ }^{202}$ When an item such as clothing, equipment, or a mop becomes contaminated, this is considered low-level waste. Materials that are produced within nuclear reactors as a byproduct of reactions (spent fuel) are considered high-level waste. Low-level wastes are typically maintained on-site until the radioactivity decays to a level that allows for safe disposal. As low-level waste decays to an acceptable level, it may also be transferred to one of the four licensed low-level waste disposal sites in the nation. ${ }^{203} 204$

\subsection{TRENDS IN NUCLEAR RETIREMENTS}

Under the Atomic Energy Act of 1954, nuclear power plants are provided licenses for 40 years. After 40 years, the license may be renewed for another 20 years. ${ }^{205}$ The NRC licenses for most nuclear units in the United States end by 2040.206 NRC is considering subsequent license renewal requirements, and will publish new guidance in 2017.207 The longer life extensions, if granted, will postpone the decommissioning process for many nuclear units. ${ }^{208}$ SNL Energy has identified a number of "at risk" nuclear plant units that could retire before their operating license expires, amounting to a loss of approximately $10 \mathrm{GW}$ of capacity operating at capacity factors that are typically in the $90-100 \%$ range. ${ }^{209}$ These are in addition to the four nuclear units that shut down in 2014-15, and the five units that were announced to be retired in the near future: Entergy's Pilgrim

\footnotetext{
xii http://www.nrc.gov/waste/spent-fuel-storage/sf-storage-licensing/cert-process-casks.html, Accessed March 21, 2016.

xiii http://www.nrc.gov/reading-rm/doc-collections/fact-sheets/dry-cask-storage.html
} 
Nuclear Power Station in Massachusetts and James A. Fitzpatrick Nuclear Power Plant in New York, and Exelon's Clinton and Quad Cities Nuclear Plants in Illinois, and Oyster Creek Generating Station in New Jersey.210 211212213

At the same time, five new nuclear reactors are under construction: one at Watts Bar in Tennessee, two units at Plant Vogtle in Georgia, and two units at V.C. Summer in South Carolina. NRC issued an operational license in October 2015 for the Watts Bar 2 reactor. When it comes online, it will become the first new unit to operate since the 1990s. Seven more reactors are awaiting licensing. ${ }^{214}$

\subsection{DECOMMISSIONING: WASTE STREAMS, REGULATIONS, AND COSTS}

Decommissioning refers to taking a nuclear reactor or facility offline and reducing residual radioactivity to a level that allows either the release of the property for unrestricted use or release of the property under restricted use such that public access is controlled. ${ }^{215}$ The decommissioning process is being aided by evolving technology such as 3-D imaging that reduces the chances of radioactive exposure by replicating the dismantling process in a virtual environment. Robots and remote manipulators can also be used to study the severity of waste and assist with decontamination. ${ }^{216}$ The NRC requires a plant to complete decommissioning within 60 years of ending operations.

Since 1996, plant owners must provide NRC detailed decommissioning plans before the process can commence. A plant licensee must provide the NRC periodic updates on the status of their decommissioning fund for the nuclear reactors they own. Shortfalls precipitate penalties. Licensees must perform operations in a manner that ensures the level of residual radioactivity on the site is limited. They may also need to conduct surveys to determine if high levels of residual radioactivity are found in the soil or water. The licensees must maintain records of this radioactivity, and other levels of radioactivity at the site. Decommissioning costs and costs spent on fuel management must be updated every year. ${ }^{217}$

Since the 1990s, the NRC has provided the opportunity for licensees to sell portions of facility land if they meet NRC release criteria. In this case, licensees retain other sections of land that remain under regulation of NRC for "independent spent fuel storage installations" (ISFSI). ${ }^{218}$ Further regulation mandates that operators of new nuclear reactors outline how they will be designed and operated in a manner that will simplify the decommissioning process. Since 2010, regulations require plant operators to be more proactive in decontamination prevention and cleaning when an accident does occur. ${ }^{219}$ 
NRC and ISFSI licenses are issued first for decommissioning and then for dismantling (Figure 4.2).

Figure 4.2 Decommissioning Related Activities During the Life Cycle of a Nuclear Power Plant ${ }^{220}$

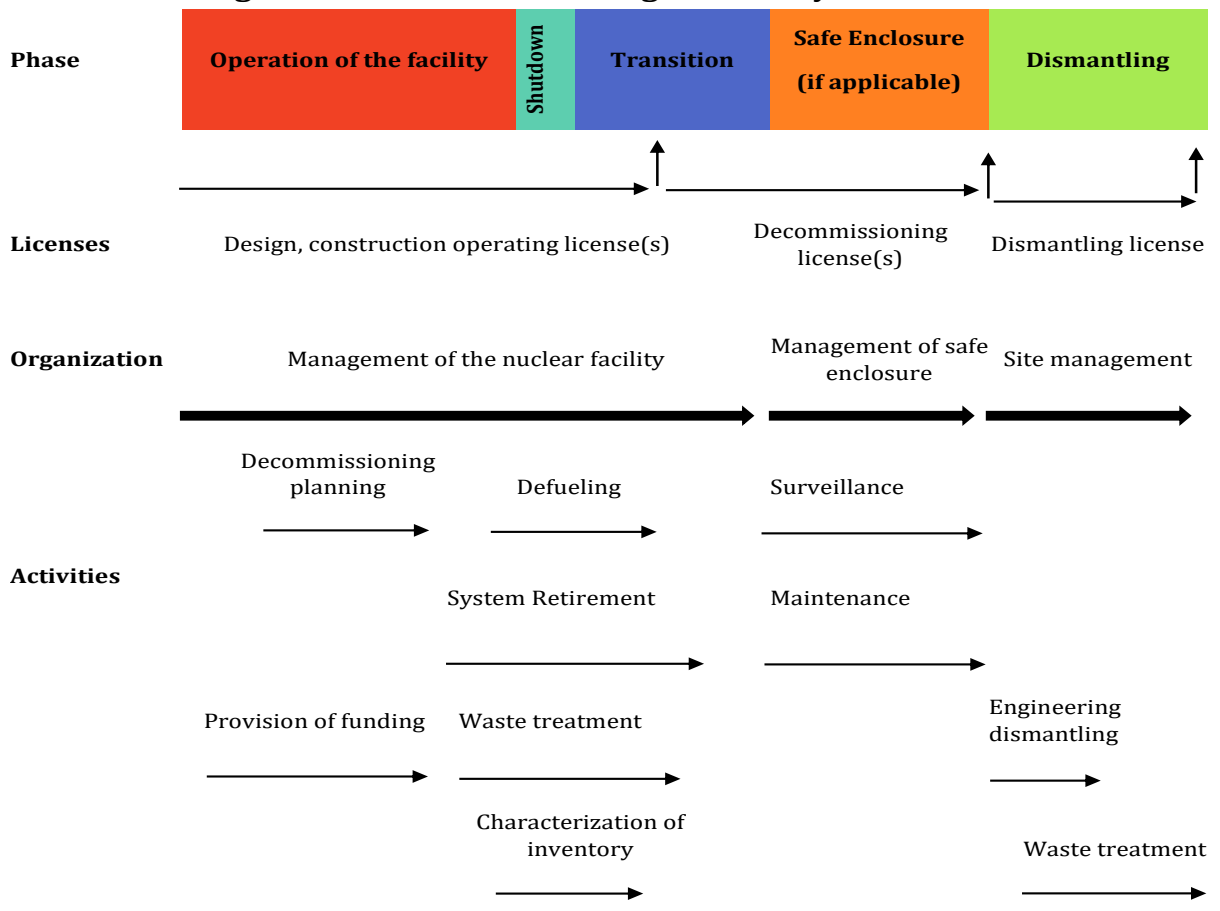

The nuclear plant owner is responsible for all of the costs associated with decommissioning and dismantling. Until 2014, plant owners also paid into the Nuclear Waste Fund that compensated DOE for taking title to used nuclear fuel. Previous decommissioning costs of commercial nuclear reactors have ranged widely from $\$ 100$ million to $\$ 700$ million. ${ }^{221}$ However, the majority owner of San Onofre Nuclear Generating Station (SONGS) expects the cost of retiring three units will be over $\$ 4$ billion. ${ }^{222}$ Officially, NRC estimates costs at about $\$ 350$ million per reactor. Multiple factors including location, size, and distance to disposal facilities affect the cost of decommissioning. 223 Disposal of low-level radioactive waste is far more costly than disposal of solid or even hazardous waste, and could be an order of magnitude more expensive, depending on the characteristics of the waste. ${ }^{224}$ To help cover these costs, utilities place around 0.15 cents $/ \mathrm{kWh}$ towards a decommissioning fund to allow timely decommissioning by removing the most significant source of radiation. ${ }^{225}$ Nearly $70 \%$ of the decommissioning fund for the United States fleet of nuclear reactors has been collected. ${ }^{226} \mathrm{At}$ this time, the average reactor requires another $\$ 300$ million to cover the costs of decommissioning. ${ }^{227}$

In the case of Connecticut Yankee, while a $\$ 400$ million clean-up fund was established, this was unable to cover the actual cleanup cost of $\$ 1.2$ billion. The presence of strontium contamination in both the soil and water caused the higher than anticipated costs. As a result, ratepayers paid the difference. ${ }^{228}$ 


\subsection{OPTIONS FOR DECOMMISSIONING}

In the coming decades, plant owners and regulators will have to decide if their aging facilities can still provide clean and safe energy efficiently, and in a manner that is economically profitable. Over time, the NRC must decide if it is better to renovate plants or to shut them down. ${ }^{229}$ If the decision to shut down is chosen, the decommissioning process will commence. ${ }^{230}$

The drafting of a decommissioning plan during the construction phase has previously minimized costs and simplified the decommissioning process. ${ }^{231}$ This plan is also advantageous in the event of an unexpected sudden shutdown. ${ }^{232}$ The decommissioning process begins with the transition period. During this timeframe, dangers should be removed and the facility should be placed in a clearly stable condition. Reactors must be defueled. Plant owners should create a database of materials and wastes based on how the materials and wastes are stored, treated, or disposed of. ${ }^{233}$

Three of the most paramount considerations when developing a decommissioning plan are the radiological contamination, condition, and configuration of the plant. The amount and level of waste are important to the planning process. Project managers must also choose between transferring low-level waste for decontamination or decontaminating it on-site. ${ }^{234}$ Decommissioning requires both managing and removing radioactive material. Planning prior to decommissioning should begin at least five years before the plant is scheduled to close. ${ }^{235}$

About $99 \%$ of the radioactivity at a nuclear reactor is associated with the fuel that is removed following permanent shutdown. ${ }^{236}$ Besides some surface contamination of the plant, radioactivity also comes from steel that has been exposed to neutron irradiation, especially the reactor vessel where stable atoms are changed into isotopes such as iron-55, iron-59, and zinc-65 that are highly radioactive. However, their half-lives are short enough that the occupational risk to workers is largely gone 50 years after the reactor shuts down. ${ }^{237}$

Two decommissioning methods (SAFSTOR and DECON) have been used in varying frequency since the first United States nuclear reactors were decommissioned in the 1960s (Figure 4.3). The International Atomic Energy Agency (IAEA) has established these three decommissioning options worldwide. In all three options, waste is either stored in a dry cask or concrete, or transported to an appropriate disposal site. The site is then decontaminated and structures dismantled. 
Figure 4.3 Methods Used to Decommission Nuclear Power Reactors in the United States, By Year of Plant Closure 238

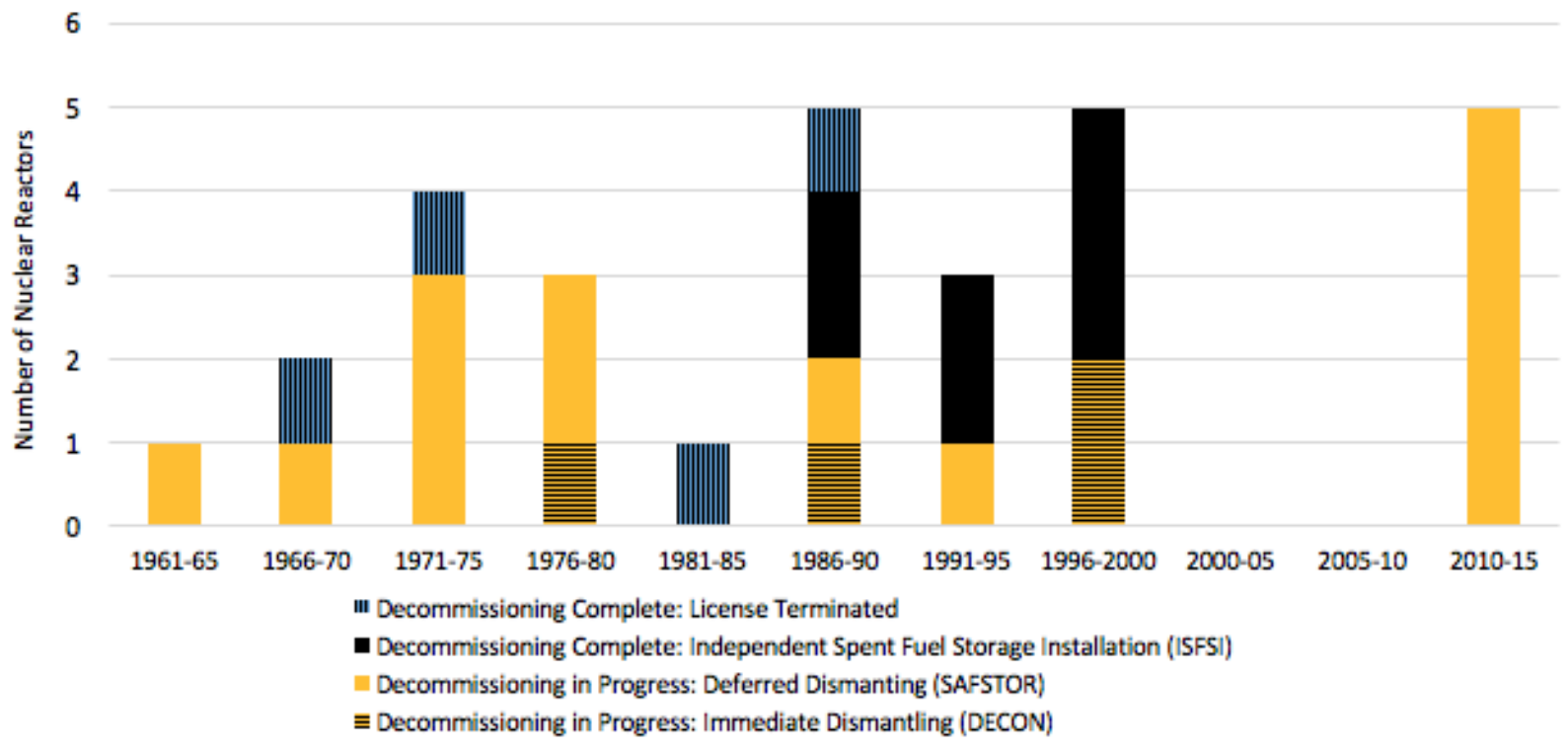

The images in Figure 4.4 depict the initial decommissioning process and the different decommissioning strategies, followed by termination of the license.

Figure 4.4 Phases of the Decommissioning Process. ${ }^{x i v}$
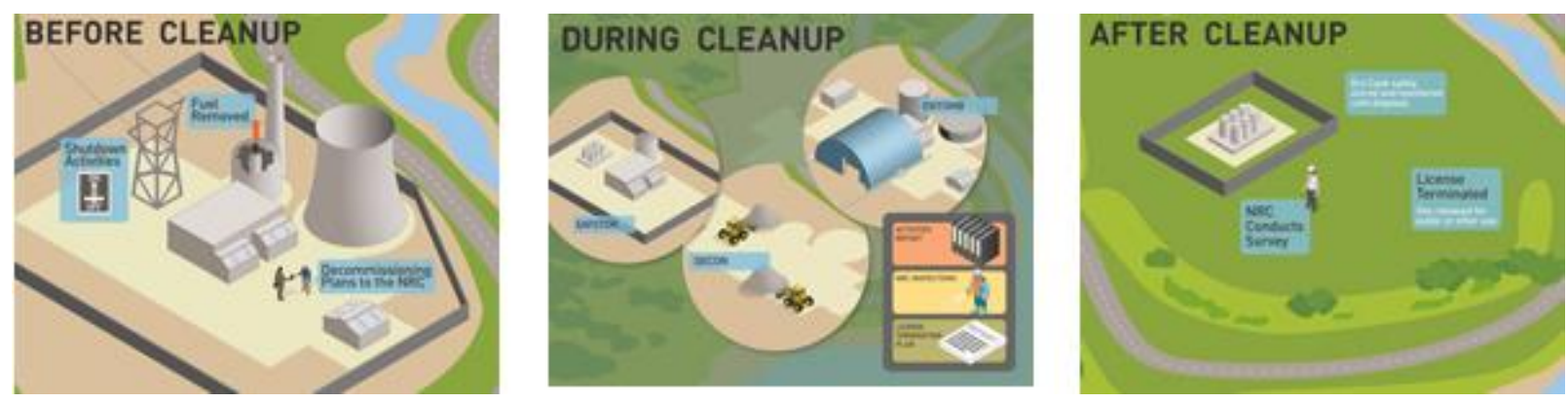

Before Cleanup: Decommissioning plans are given to NRC, fuel is removed, and activities are shutdown.

During Cleanup: SAFSTOR (Left), DECON (Middle), and ENTOMB (Right). NRC inspectors visit the site, and a planning report and license termination plan are given to NRC.

After Cleanup: Dry casks are safely stored and monitored until disposal. NRC conducts a survey. The license is terminated, and the site is released to the public or for other use.

\subsubsection{Immediate Dismantling ("DECON")}

The first method, "DECON", refers to immediate dismantling. Under this strategy, all radioactive material is either stored in dry casks or removed. This enables the operating license to be

xiv http://www.nrc.gov/reading-rm/doc-collections/fact-sheets/decommissioning.html 
terminated, while still maintaining the spent fuel storage license. ${ }^{239}$ Dismantling activities can commence within months or years. Once the dismantling process is complete, most of the site can be reused. This has been the most common approach used in the United States. ${ }^{240}$ A site can be fully decommissioned and still have dry cask storage on it. This was the case with Maine Yankee. In these cases, the site is partially released for reuse.

For example, San Onofre unit 1 was closed in 1992 and became an active DECON project in 1999 after considering the SAFSTOR option. Its decommissioning was largely completed in 2008 . Units 2 and 3 were shut down in 2013, and they will eventually be dismantled. ${ }^{241}$

\subsubsection{Safe Enclosure ("SAFSTOR")}

The second method, "SAFSTOR", refers to deferred dismantling. Under this strategy, the fuel must be permanently removed from the reactor, while the plant is maintained until the radioactivity has decayed. Once this has occurred, the facility is decontaminated and dismantled. ${ }^{242}$ The period to wait for residual radioactivity to decay is typically 50 years, which is when full decommissioning is planned to occur. ${ }^{243}$ SAFSTOR decommissioning must be completed within 60 years.

Duke's Crystal River Unit 3 is an example of using the SAFSTOR method at an estimated cost of $\$ 1.2$ billion (excluding the cost of decommissioning at the end). Its costs will be fully covered by the funds reserved for that purpose that have been accruing interest. SAFSTOR began in 2015 after fuel was removed from the reactor; it will end with removal of the unit's remaining components in 2070 and site restoration in 2074. ${ }^{244}$ Through most of 2019, the spent fuel is to remain in pools. After that, it will be held in dry cask storage onsite until 2036. Once DOE accepts the spent fuel at a federal facility, the cooling ponds will be drained, cleaned and filled in, and the turbine hall will be dismantled and demolished and the waste removed or recycled. The site will then be leveled and landscaped. ${ }^{245}$

\subsubsection{Entombment (“ENTOMB”)}

The "ENTOMB" method refers to placing radioactive materials in a structurally sound encasing like concrete. The owner continues to monitor and maintain the facility. Once the radioactivity decays to an acceptable level, the site can be vacated according to the permit. This option has never been exercised by an NRC licensed plant. 246247 The only United States plants using the ENTOMB option are all experimental reactors.

\subsubsection{Discussion of Options for Decommissioning}

SAFSTOR is a beneficial strategy to employ since the risk of workers being exposed to radiation significantly diminishes. ${ }^{248}$ Additionally, advancements in technology will likely make decommissioning less expensive in the future. ${ }^{249}$ However, this strategy faces the possibility that $\mathrm{NRC}$ regulations will be amended, which may ultimately cost the plant manager more. DECON removes this uncertainty with immediate dismantling, and also does not push the decommissioning process onto future generations. ${ }^{250} 251$ However, the DECON method may lack a place to dispose of highly radioactivity spent fuel. Depending on availability of disposal sites, a portion of the facility 
can be placed in SAFSTOR while the rest is in DECON. ${ }^{252}$ ENTOMB is a difficult strategy because of the amount of radioactive material and length of time its half-life requires to decay. It is a more viable option for smaller experimental reactors. ${ }^{253}$

\subsection{CHAPTER CONCLUSIONS}

Nuclear energy is a clean energy source that can provide baseload power with high capacity factors. As a result, it is a valuable and nearly carbon-free energy source. ${ }^{254}$ However, its nuclear waste requires careful handling. There is currently no centralized waste facility for nuclear waste in the United States. for permanent disposal, so waste is stored at reactor sites in 35 states awaiting construction of a permanent waste handling facility. Other countries recycle spent fuel rods, but this process is currently not used in the United States due to economic and security concerns.

Decommissioning costs of commercial nuclear reactors have ranged widely from $\$ 100$ million to $\$ 700$ million. In some cases, clean-up costs have exceeded \$1 billion. ${ }^{255} 256$ Multiple factors including location, size, and distance to disposal facilities affect the cost of decommissioning. 257 


\section{RENEWABLES}

\subsection{BASIC OVERVIEW OF RENEWABLE ENERGY}

Renewable energy comes from resources that are continuously replenished by nature such as the sun, wind, and water. Through the utilization of technologies, these resources are made into useable forms of energy. Renewable energy is suitable for both large-scale and small-scale projects. Due to the minimal production of air pollutants and limited needs for fossil fuels during normal operations, electricity powered by renewable resources has lower environmental impacts than conventional energy resources.

Renewable resources in the United States accounted for $13.5 \%$ of domestically produced electricity in $2015^{\mathrm{xv}}$, with hydroelectric power accounting for the largest share (46\%). From 2009 to 2015, wind electricity production almost doubled its capacity. Significant solar capacity increases have also occurred since 2009.

The development of renewable energy is expected to grow in the coming years. EIA projects that total renewable energy used in the power sector will increase by $8.7 \%$ in 2016 and $6.5 \%$ in 2017 . Solar PV capacity is expected to increase from $10 \mathrm{GW}$ to $27 \mathrm{GW}$ between 2014 and 2017. xi Wind capacity is expected to increase by $9 \%$ in 2016 and by $8 \%$ in 2017, accounting at that point for $5.6 \%$ of total generation. Because hydropower represents the largest share of U.S. renewable energy resources, and wind and solar generation are the most rapidly growing renewable energy resources, this report focuses on these renewable energy sources in addition to conventional power generation systems.

XV

xvi https://www.eia.gov/forecasts/steo/report/renew co2.cfm 
Figure 5.1. United States Renewable Electricity Production (billion kWh) by Source 258259

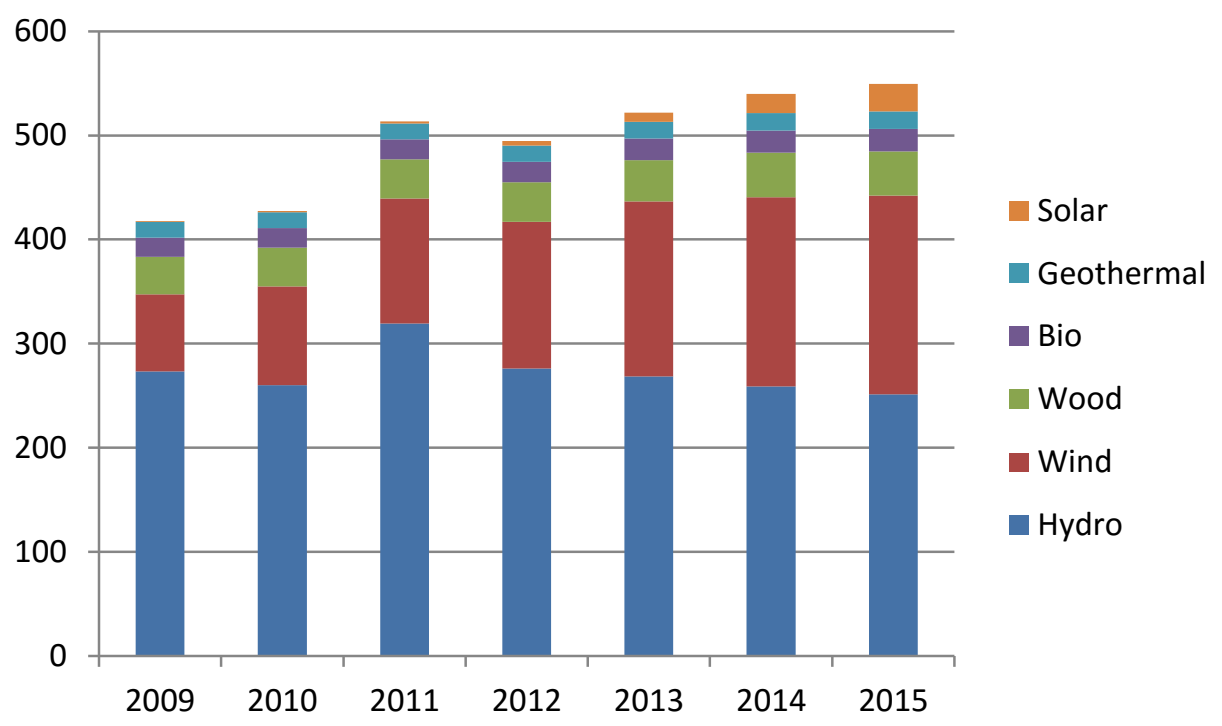

\subsection{HYDROELECTRIC POWER}

In 2015, hydroelectric power was the largest source of renewable electricity in the United States, generating about $6 \%$ of the nation's total electricity. The most common form of hydropower uses a dam on a river to hold a large reservoir of water. Water is then released through turbines to generate power. Conversely, "run of the river" systems divert water from the river and direct the water through a pipeline to a turbine. Many of these dams were pivotal to economic and social development, enabling economic growth and contributing to national security. Thousands of these existing dams now provide multiple benefits including management of water for industrial and municipal supply, agricultural, flood control, recreation, and power generation purposes. ${ }^{260}$

With 79.64 GW of total capacity, there are 2,198 active hydropower plants in the United States. ${ }^{261}$ As shown in Figure 5.1, largest hydropower plants were built between 1930 and 1970. Nearly half of the installed capacity is owned by federal agencies including the U.S. Army Corps of Engineers, Bureau of Reclamation, and the Tennessee Valley Authority. According to American Rivers, 1,300 dams were removed to restore rivers between 1912 and 2015.262 Most recently, 62 dams were removed in 2015.xvii Because the size and location of dams vary, the cost to remove an individual dam can range from tens of thousands of dollars to hundreds of millions of dollars. ${ }^{263}$ It is estimated that $\$ 16$ billion is needed to rehabilitate the nation's most critical dams. ${ }^{264}$ Since 2005 , at least $\$ 6$ billion has been spent in refurbishments, replacements, and upgrades to hydropower plants. ${ }^{265}$

xvii $\underline{\text { http://www.americanrivers.org/wp-content/uploads/2014/02/Dam-List-2015.pdf?c38e77 }}$ 
Figure 5.2. Hydropower Plant Installation Timeline 266

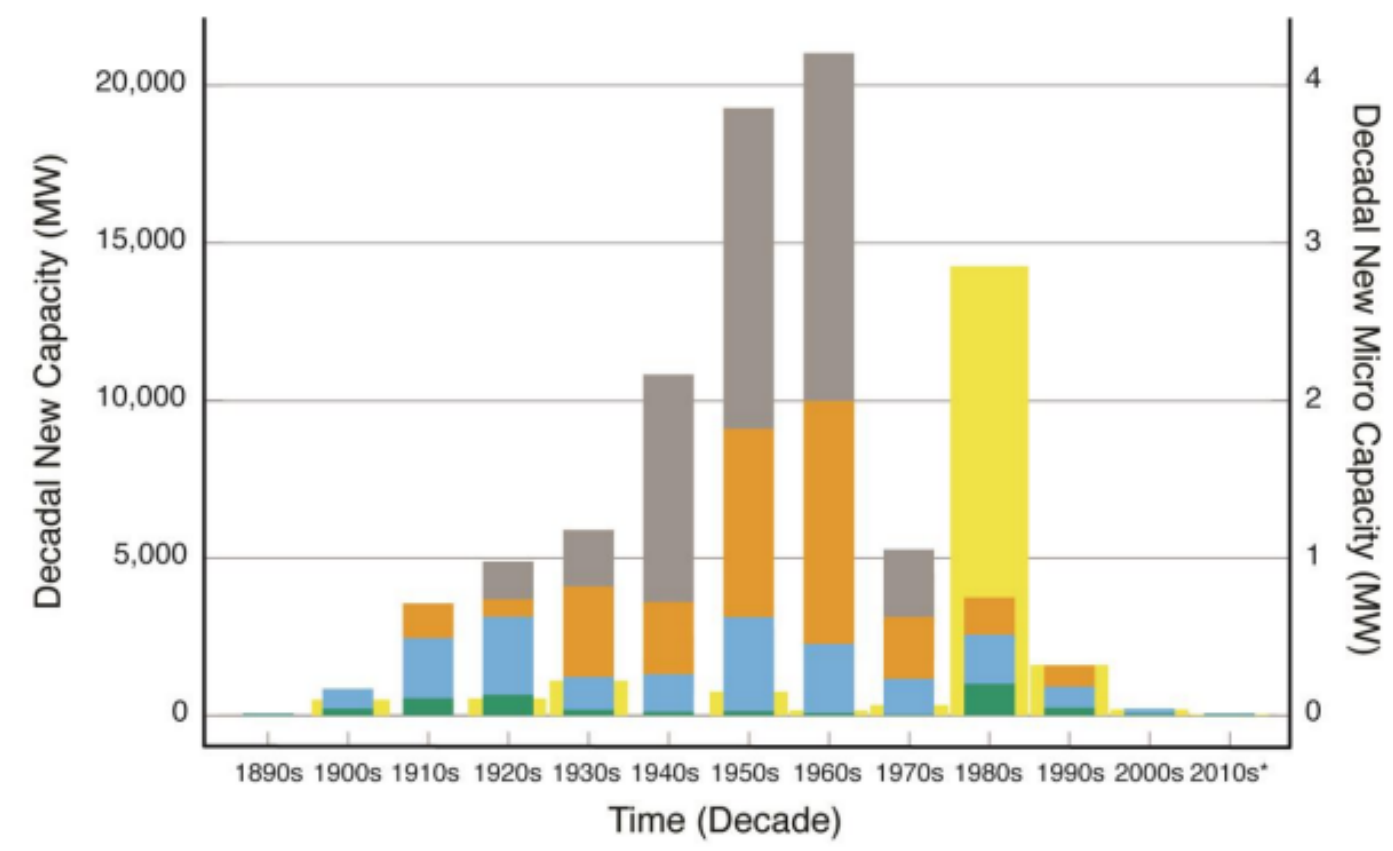

Very Large (>500)

Large (>100-500)

Sizes (MW)

Medium (>10-100)

Small $(>0.1-10)$

Micro $(<=0.1)$

\subsubsection{Regulations}

Dams are owned and regulated by a variety of organizations within the United States. Roughly half of the hydropower plants are privately or municipally-owned, and state regulated. ${ }^{267}$ On December 22, 2006, the Dam Safety Act of $2006^{268}$ was signed into law. This legislation aims to, "Reduce the risks to life and property from dam failure in the United States through the establishment and maintenance of an effective national dam safety to bring together the expertise and resources of the Federal and non-Federal communities in achieving national dam safety hazard reduction." The Wetlands Protection Act and other wetland regulations acknowledge the importance of dam safety. The Interagency Committee on Dam Safety (ICODS) was established in 1979, and encourages the establishment and maintenance of effective federal programs, policies, and guidelines to enhance dam safety for the protection of human life and property. Through technology and procedures, The National Dam Safety Program ensures the safety of new and existing dams.

The Dams Sector-Specific Agencies actively collaborate with sector stakeholders to identify and implement programs. One example is the National Dam Safety Program, which enhances the protection and resilience of dams across the nation. The collaborative partnership between government and non-government entities across the Dams Sector has resulted in the development of various tools and products that focus on improving protection and enhancing resilience. For example, the Risk Prioritization Tool for Dams helps decision makers understand important contributors to dam risks. 
As a result of changes in regulations and electricity markets, the regulation of hydropower plants has evolved over time. Introduction of new regulations including the Wild and Scenic Rivers Act (1968), the National Environmental Policy Act (1969), the Clean Water Act (1972), and the Endangered Species Act (1973) changed the way in which the environmental effects of hydropower operations are mitigated. As a result of the Federal Power Act, all FERC licensed projects require FERC be involved in a dam decommissioning project. The Clean Air Act (CAA) protects the quality of the nation's air resources, and promotes public health as a result. Due to the heavy construction equipment, dam removal may also impact air quality. Since a large dam decommissioning project can change the extent of flooding impacts, maps developed for the National Flood Insurance Program may require updating. Although FEMA does not have statutory permitting authority for dam decommissioning projects, it may be consulted by USACE during the permit review process.

Other renewable technologies, including wind and solar, have made significant use of federal tax incentives to offset costs. The Production Tax Credit (PTC) and the Investment Tax Credit (ITC) have been two of the most frequently utilized incentives. However, the hydropower industry received less incentives than other renewable energy sources. Although, hydropower's eligibility for federal tax incentives has evolved significantly over time, and all recent additions and new projects have offered incentives. Incentives provided by the American Reinvestment and Recovery Act have helped both public and private owners to support project development efforts. This has substantially eased project economics. The 1603 Grant Program, Clean Renewable Energy Bonds, and Build America Bonds supported development activity of new hydropower plants ( $\$ 1.6$ billion) by private owners. ${ }^{269}$

While state regulations vary by state, they are often similar to federal regulations. For example, California has its own Environmental Quality Act (CEQA), Endangered Species Act (CESA), and Clean Air Act (CCAA). The permitting requirements may also differ by state. For example, in Connecticut, unless federally owned, a single state permit administered by the Department of Environmental Protection (DEP) Inland Water Resources Division is required to remove a dam. The Connecticut state permit application requires supporting documentation regarding dam safety issues, as well as wetland, fisheries, and historical impacts. In Massachusetts, several state permits are typically required to remove a dam. The project proponent must individually apply for permits from various state agencies, such as the Massachusetts Department of Environmental Protection (DEP) and the Office of Dam Safety. Local regulations vary by location and are specific to the project area. Counties, cities, towns, and other local bodies may require a wide array of permits covering areas including zoning, administrative uses, road encroachment, wetlands impacts and mitigation, transportation, floodplain development, grading, hazardous materials, construction, operation, burning, fugitive emission controls, air pollution controls, demolition, waste disposal, recycling, and erosion and sediment control. 270 


\subsubsection{Decommissioning}

The continuous operation of a hydroelectric plant often involves rehabilitation projects to address safety and security issues, and to address any any licensing conditions. Hydroelectric upgrades for power generation improvement are also typical. In addition, there are two options for decommissioning a hydropower plant:

1. Partial Retirement: Retirement of only the hydroelectric facilities results in retaining the dam and other structures. However, some rehabilitation of the structure for safety or maintenance may be required. Partial retirement of the project facilities includes the hydroelectric facilities, if present, and/or reduction in height or breach of the dam. In this case, the dam is either reduced or eliminated, while some of the ancillary facilities may remain intact.

2. Full Demolition: This is defined as a removal of the project and all appurtenant structures that include rehabilitation or restoration of the affected project area. Reasons for removing a dam could physical obsolescence, environmental concerns, economics, safety criteria, risk reduction, and operating and maintenance costs. Many older dams also do not meet current

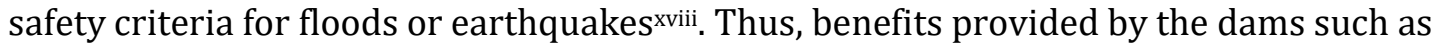
hydropower generation may not justify upgrading or rebuilding the dam. One of the primary motivations for removing a dam is to protect fish and restore their habitat. Factors that drive full demolition include costs, environmental impacts, funding, fish passage requirements, public safety requirements, and river restoration.xix

The first step in the decommissioning process is to study all alternatives, including repairs and upgrades. The main steps of the decommissioning process (provided by U.S. Society on Dams [USSD]) are: review alternatives; select decommissioning; develop a consensus with stakeholders; complete permitting/public information processes; lay out the impact assessments and engineering design; complete an environmental impact statement (EIS) and legal applications; and then remove the dam. ${ }^{271}$ Every dam removal process is different and will have site-specific engineering, environmental, and community issues. Table 5.1 summarizes the general steps in a dam removal project, based on the procedures specified by the state of Massachusetts. ${ }^{272}$

xviii http://www.ussdams.org/c_decom.html

xix http://ussdams.com/proceedings/2012Proc/855.pdf 
Table 5.1. Dam Removal Steps ${ }^{x x}$

\begin{tabular}{|c|c|}
\hline Task & Description \\
\hline Initial Reconnaissance & 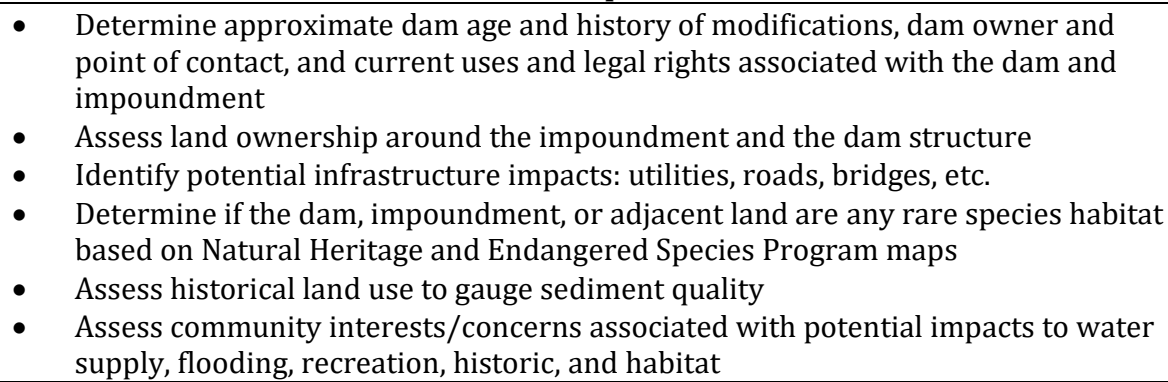 \\
\hline $\begin{array}{l}\text { Site Visit and Planning } \\
\text { Meeting }\end{array}$ & $\begin{array}{l}\text { - Conduct a site visit with project proponent, dam owner, local, state, and federal } \\
\text { agencies to plan next steps }\end{array}$ \\
\hline Feasibility Study & 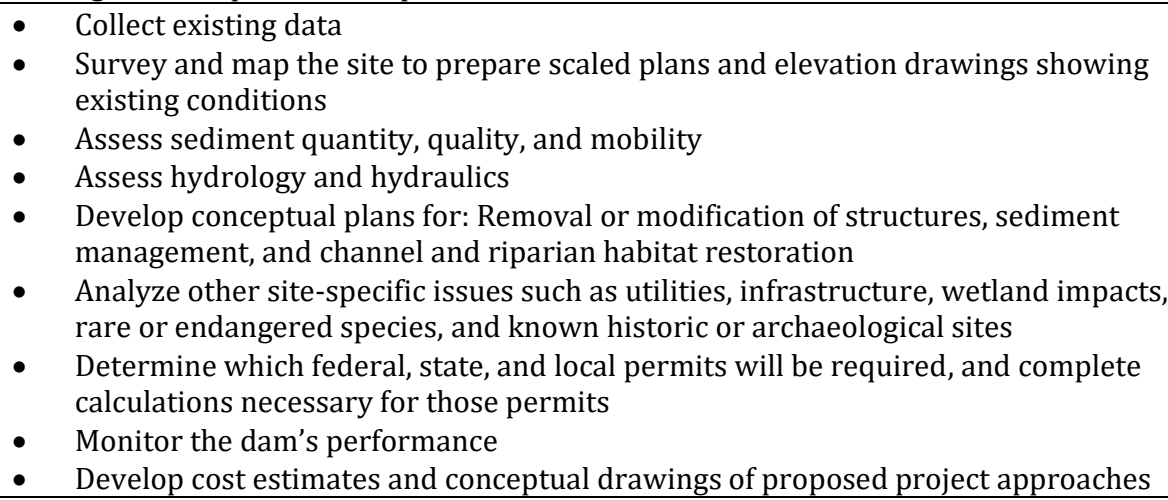 \\
\hline $\begin{array}{l}\text { Working with the } \\
\text { Community }\end{array}$ & $\begin{array}{l}\text { - Stakeholder/community meeting(s) to review alternatives and obtain local } \\
\text { support for a preferred alternative } \\
\text { Pre-permitting meeting with local, state and federal planners and environmental } \\
\text { regulators, dam safety officials, and local historical commission to clarify and } \\
\text { confirm regulatory review requirements if necessary }\end{array}$ \\
\hline Final Engineering Design & $\begin{array}{l}\text { - Develop engineering design plans for the preferred alternative, which may } \\
\text { propose modification, or dam removal and stream restoration } \\
\text { - Develop project specifications that specify necessary construction equipment, } \\
\text { material specifications and quantities, project sequencing, staging areas, and site } \\
\text { access } \\
\text { - } \quad \text { Provide an engineer's cost estimate for construction }\end{array}$ \\
\hline Permitting & $\begin{array}{ll} & \text { File all regulatory permits } \\
- & \text { Attend public hearings } \\
\text { - } & \text { Address public and regulatory agency comments and permitting conditions } \\
\end{array}$ \\
\hline $\begin{array}{l}\text { Project Implementation and } \\
\text { Construction }\end{array}$ & $\begin{array}{ll}- & \text { Hire contractors } \\
- & \text { Drawdown impoundment } \\
\text { - } & \text { Address impoundment sediments as necessary } \\
\text { - } & \text { Remove dam structure } \\
\text { - } & \text { Restore stream channel } \\
\text { - } & \text { Revegetate impoundment } \\
\end{array}$ \\
\hline
\end{tabular}

\subsubsection{Issues Related to Dam Removal}

Environmental Concern: There are multiple potentially beneficial and harmful environmental considerations related to dam removal. Fish passage and/or dam removal would allow fish to move, and therefore may affect the population size of specific species either upstream or downstream of

xx Text in this table is taken from a report "Dam removal in Massachusetts: A Basic Guide for Project Proponents" http://www.mass.gov/eea/docs/eea/water/damremoval-guidance.pdf 
the dam. Accumulation and storage of sediments in reservoirs are another concern during decommissioning. This is because the suspended solids contained in runoff are likely to settle in the quiescent reservoir waters. The quantity and type of sediment that has collected behind the dam is critical. In industrial areas, these sediments may contain contaminants like metals, oil, grease, and many other chemicals. In rural areas, agricultural operations may lead to contaminants such as pesticides and herbicides. Accumulating sediments in reservoirs can contain noticeable levels of carbon that may be released to the atmosphere upon dam decommissioning. ${ }^{273}$ Therefore, before removing a dam, the sediments must be tested for toxins since these they may be carried downstream, and may get deposited along stream banks, stream bottoms, backwater, and floodplain areas. If mussels get affected, it may take years for them to re-establish their population. However, it will take less than a year for macroinvertebrates. ${ }^{274}$ Thus, the primary environmental considerations for dam removal are fish habitat restoration, wetland creation and loss, and sediment release

Economic Issues: The largest decommissioning economic concerns relate to operating and improving an aging dam. ${ }^{x i}$ Thus, vigilant advance planning should consist of studying analysis of alternatives, preliminary cost estimates, permitting requirements, and consensus-building with concerned parties. ${ }^{275}$ Other economic losses due to discontinuing dam operation include flood control, irrigation, power generation, recreational uses, etc.

The Elwha Ecosystem Restoration project on the Olympic Peninsula of Washington was the largest dam removal project in history. The demolition project lasted from 2012-2014. The 108 foot Elwha Dam and the 210 foot Glines Canyon Dam were removed to restore stocks of Pacific Salmon and trout species to the Elwha River watershed. The removal of these blockades allowed migratory salmon to travel past the dam sites and upriver, an event that had not occurred since the dams were created in 1913.xxii These dams had virtually eliminated bed-material sediment supply to the river downstream and formed large deltas upstream of each reservoir. Once released, the sediment traveled downstream to the mouth of the river where a new estuary is believed to be forming. These geomorphic alterations have important ecological implications. They affect aquatic habitat structure, benthic fauna, salmonid spawning, and rearing potential and riparian vegetation. For example, within a year of the Elwha Dam removal, an increase in salmon-derived nutrients was documented in the American dipper. ${ }^{276}$ The response of the Elwha River system to the dam removals provides a unique and important case study for future river restoration projects. ${ }^{277}$

Removal of Elwha Dam: The first step was to lower the reservoir's water level by approximately 15 feet by using the existing water intakes and spillways. This began on June 1, 2011. A temporary diversion channel was then excavated through the left spillway to allow further drainage of Lake Aldwell. Temporary structures, acting as dams, were installed to direct reservoir outflow into the temporary diversion channel. This allowed the remaining water immediately behind the concrete dam to pump out, and the fill material behind the dam to be removed under dry conditions. The concrete dam was then removed, and original river channel was restored. The powerhouse and all

\footnotetext{
xxi Translating physical changes like number of fish, miles of riparian habitat, flow levels, etc. into economic values is difficult.

xxii http://www.elwhascienceed.org/project-update/elwha-salmon-populations
} 
other structures were then removed, and the temporary diversion channel was refilled. Finally, the site was re-contoured and revegetated to most closely resemble the pre-dam condition.xxii The timeline of deconstruction of the Elwha Dam, the most complex part of the three-year project, is explained in Table 5.2 .

Table 5.2. Deconstruction of the Elwha Dam ${ }^{x i v}$

\begin{tabular}{clc}
\hline Task & \multicolumn{1}{c}{ Description } & Timeline \\
\hline 1 & $\begin{array}{l}\text { Open the four spillway gates on the south side of the dam to lower the } \\
\text { level of the Lake Aldwell reservoir 18 ft. }\end{array}$ & 1 month \\
\hline 2 & $\begin{array}{l}\text { Remove the south gates and dig a diversion channel. Blast a 30 x 35 ft. } \\
\text { plug of bedrock in five stages and reroute the river through the gap. }\end{array}$ & 3 months \\
\hline 3 & $\begin{array}{l}\text { Take out the north spillway and upper portion of the dam and install a } \\
\text { 12- ft. wide road, in order to access the penstock tubes. }\end{array}$ & 1 month \\
\hline 4 & $\begin{array}{l}\text { Remove steel penstocks and slide gates, the concrete intake structure } \\
\text { and powerhouse. }\end{array}$ & 5 months \\
\hline 5 & $\begin{array}{l}\text { Haul out 200,000 cubic yards of rock, earth, concrete and fir trees that } \\
\text { were placed behind the gravity dam after a 1913 bust. }\end{array}$ & 8 months \\
\hline 6 & $\begin{array}{l}\text { Remove the concrete gravity dam 7 to 10 ft. at a time using explosives, } \\
\text { and restore the natural river channel. }\end{array}$ & 2 months \\
\hline
\end{tabular}

Figure 5.3. Glines Canyon Dam on the Elwha River on September 6, 2011; Removal of Glines Canyon Dam on January 19, 2012.xxv
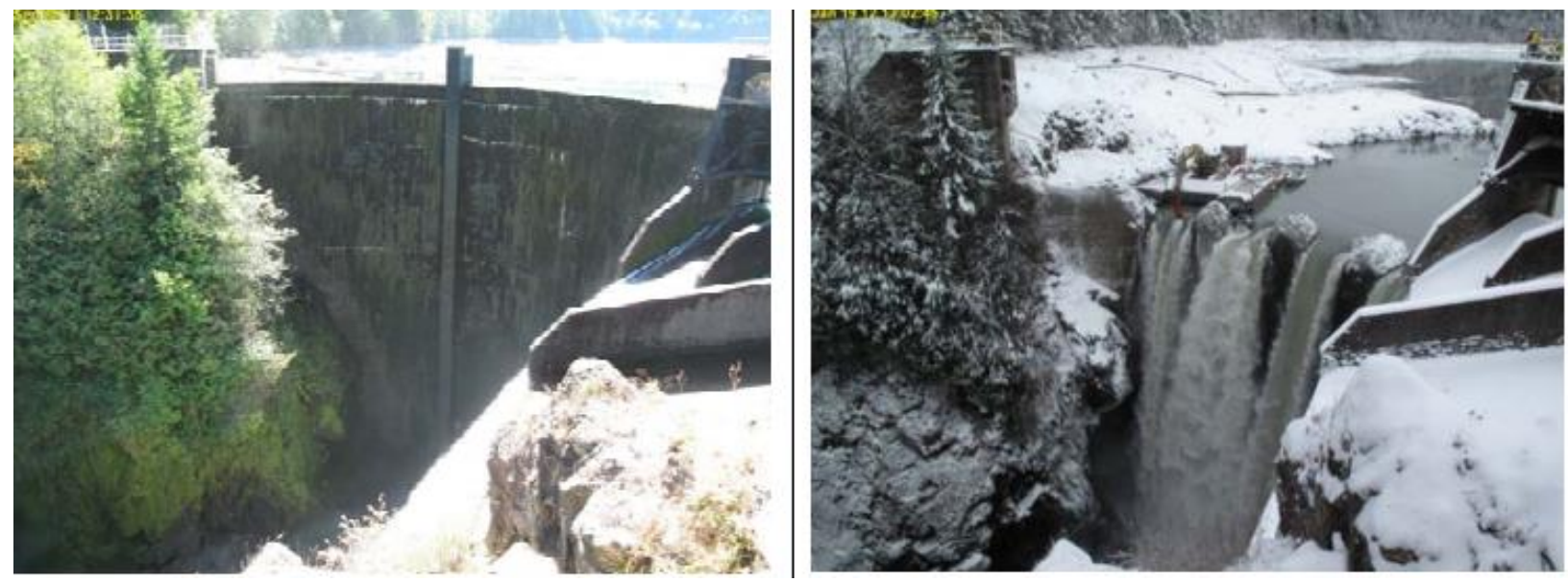

\subsection{WIND}

Wind turbines capture the kinetic energy present in wind and converts it into electrical energy. Utility-scale turbines are mounted on tall towers, usually 300 feet or more above the earth's surface, where the wind is faster and less turbulent. ${ }^{278}$ According to the American Wind Energy Association (AWEA), wind energy reached 74.5 gigawatts (GW) of installed capacity with over

\footnotetext{
xxiii http://www.nps.gov/olym/learn/nature/dam-removal-overview.htm

xxiv Text in this table is taken from a report "How to Tear Down a Dam"

http://www.nps.gov/olym/learn/nature/upload/Elwha-Dam-in-Popular-Mechanics-2.pdf xxv http://ussdams.com/proceedings/2012Proc/855.pdf
} 
50,000 wind turbines, and about $8000 \mathrm{MW}$ of wind capacity was installed in 2015.279 Wind power grew by $13 \%$ in 2015 and is forecast to increase by $8 \%$ in $2016 .{ }^{280}$ In 2017 , it is expected that wind generation will account for $5.6 \%$ of total generation. ${ }^{281}$ This rapid rate of growth is due partly to the extensions of the wind production tax credit (PTC) and the solar investment tax credit (ITC) that were implemented by the Consolidated Appropriations Act in 2015. xxvi The PTC provides a 2.3 cent per kWh tax credit for the first 10 year of production for plants that are under construction by the end of 2016. The PTC was extended for five years, but the value of the credits decline over the 5-year period. The ITC provides a $30 \%$ tax credit for the cost of developing solar energy projects through 2019 , when the credit declines incrementally until 2022, when it expires for residential projects and drops to $10 \%$ for utility and commercially operated solar projects.

\subsubsection{Regulations}

There are currently no national regulations for decommissioning wind plants. However, the U.S. Bureau of Land Management (BLM) has modified existing regulations to aid in the development of wind and solar energy on BLM land, and to establish competitive terms and conditions such as rental and bonding requirements. ${ }^{282}$ For example, BLM requires that solar and wind energy reclamation cost estimates include the three components listed below: ${ }^{\text {:xvii }}$

1. Environmental liabilities like securing, removal or use of hazardous materials and substances, hazardous waste, herbicide, petroleum-based fluids, and dust control or soil stabilization materials

2. The decommissioning, removal, and proper disposal of facilities

3. Interim and final reclamation, revegetation, re-contouring, and soil stabilization. This includes the potential for flood events and downstream sedimentation from the site that may result in offsite impacts; the area and acreage of disturbance; and the resources affected by the project.

It should be noted that BLM regulations apply to federal public lands through right-of-way (ROW) authorization. The BLM grants ROW authorizations in accordance with Federal Land Policy and Management Act (FLPMA) and the BLM's Wind Energy Development Policy. Decommissioning process for a wind power plant must be approved by the BLM. Not many states in the United States have decommissioning and bond requirements for wind power projects and rely on other mechanisms to implement this. ${ }^{283}$ In Minnesota, the public utility commission develops rules to govern the site restoration of large wind energy projects. Conversely, some states like Vermont and Indiana need a decommissioning plan and financial assurance before the project is approved. Some states rely on energy facility sitting evaluation committees for the decommissioning of renewable energy facilities. These committees create a state-sponsored entity to review and check energy

xxvi http://www.eia.gov/todayinenergy/detail.cfm?id=26492

xxvii

http://www.blm.gov/wo/st/en/info/regulations/Instruction_Memos and Bulletins/national_instruction/20 $\underline{15 / \text { IM 2015-138.html }}$ 
facilities and infrastructure. For example, the Oregon Energy Facility Siting Council imposes decommissioning standards on any facility within its jurisdiction through the site certification process. It reviews the plan, estimates the decommissioning cost, and requires a bond be established before the construction of the project starts. In South Dakota, local ordinances regulate the decommissioning process of wind projects under $100 \mathrm{MW}$ capacities. Anything over $100 \mathrm{MW}$ may require a bond or other guarantee for wind projects. It should be noted that state decommissioning regulations are not common, since only a few states have requirements for decommissioning wind projects (or renewable energy projects). There are no standard regulations and no minimum bond requirements in such states, and projects are evaluated on a case-by-case basis. Similarly, for wind projects on local land, the projects are evaluated case-by-case. Projects do require a financial assurance in the form of bond to cover the cost of decommissioning and reclaiming a site. These projects require approval by the appropriate county, town or regulatory authority. For example, a wind energy project in Vermillion County was approved where the developer was responsible for the full costs of decommissioning the project $(\$ 98,000$ per turbine). Table 5.3 lists states with renewable facility decommissioning rules.

Table 5.3. Summary of State Wind Decommissioning Policies ${ }^{284}$

\begin{tabular}{ll}
\hline \multicolumn{1}{c}{ States } & \multicolumn{1}{c}{$\begin{array}{c}\text { Renewable Facility Decommissioning } \\
\text { Rules/Fund }\end{array}$} \\
\hline Hawaii & Yes \\
Indiana & Yes \\
Maine & Yes \\
Minnesota & Yes \\
New York & Yes, if over 80 MW nameplate capacity \\
North Dakota & \\
Ohio & Yes, if over 5 MW nameplate capacity \\
Oregon & Yes \\
South Dakota & Yes, if over 100 MW nameplate capacity \\
Vermont & Yes \\
\hline
\end{tabular}

\subsubsection{Decommissioning}

Since solar and wind power plants possess relatively new technologies (younger than 30 years) compared to other discussed power plants, there is comparatively little information on the associated decommissioning practices and challenges of solar and wind power plants. Even the oldest utility-scale wind power projects in the United States are only about twenty years old, while wind power plants in most states are about a decade old.

Wind turbine generators that are presently available in the market have a life expectancy of over 20 years. The steel towers that support the turbines and generators have a simple and rugged design. 
With basic regular maintenance, the generators can last several years past their life expectancy. ${ }^{285}$ Following advancements in technology, the existing turbines can be replaced with more efficient and cost-effective generators that extend the life of the project. This process is known as "repowering." 286 As of $2012,75 \%$ of installed wind plant capacity was less than five years old and $8 \%$ of the installed capacity was older than 10 years. ${ }^{287}$ In the United States, projects that continue to operate after 20 years generally have little incentive to repower when the option to build new wind projects is considered. ${ }^{288}$ Outside of California, repowering demand is not likely to have a noticeable impact until the mid-to-late 2020s.

An important thing to note is that none of the utility scale wind power projects have been decommissioned, and as a result there are no standard procedures for decommissioning. ${ }^{289}$ Some landowners negotiate a decommissioning requirement into their contracts with the developers. Some jurisdictions require developers to deposit a per-turbine decommissioning bond that cannot be released until each turbine is decommissioned. Some states, including North Dakota, have statutory requirements for decommissioning.

To date, there are not many wind decommissioning projects. As a result, details of decommissioning wind projects are very limited. In some states, developers are required to have decommissioning process and cost estimates ready with the commissioning plan. In general, the decommissioning process of a wind plant consists of removing the turbine, destruction of concrete pads, restoring the surface, and replanting and rebuilding the soil of disturbed land. Communication towers are taken apart and removed which are then either disposed or recycled or reused. ${ }^{290}$ The BLM estimated that the total cost of removal varies from $\$ 3,500$ to $\$ 5,700$ per turbine for $100 \mathrm{~kW}$ turbines

Based on the decommissioning of the Black Oak Wind Farm, some experience with the removal of wind turbines and foundations is available. ${ }^{291}$ Roads that have access to turbines may need to be widened in order to move cranes or other machinery needed to disassemble and remove the turbines. High value components will be stripped while remaining materials will be reduced to shippable dimensions and transported off site. Control cabinets, electronic components, and internal cables will be removed. The blades, hub, nacelle and tower sections will be lowered to the ground where they will be further disassembled into transportable pieces. These will either be transported for reconditioned and reused, or dissembled into salvageable, recyclable, or disposable components. Parts that can be used again will be sold to the market for parts or installation elsewhere.

Again based on the decommissioning of the Black Oak Wind Farm, the removal of turbine foundations requires that the area surrounding the foundations be excavated so that all anchor bolts, rebar, conduits, cable, and concrete to a depth of 36 inches below grade can be removed. Once all the foundation materials are removed, the affected area will be filled and compressed with the material of quality similar to the adjoining area. After this, the area will be cleaned by removing all debris and vegetation is re-seeded. ${ }^{292}$

It appears that the cables and conduits in underground electrical systems do not contain any material that is unsafe to the environment, ${ }^{293}$ and substations and transformers may be returned to the transmission company or utility for possible recycle or re-use. 294 
Figure 5.4 describes the decommissioning process of wind turbines.

Figure 5.4. Decommissioning of Wind Farms ${ }^{x x v i i i}$

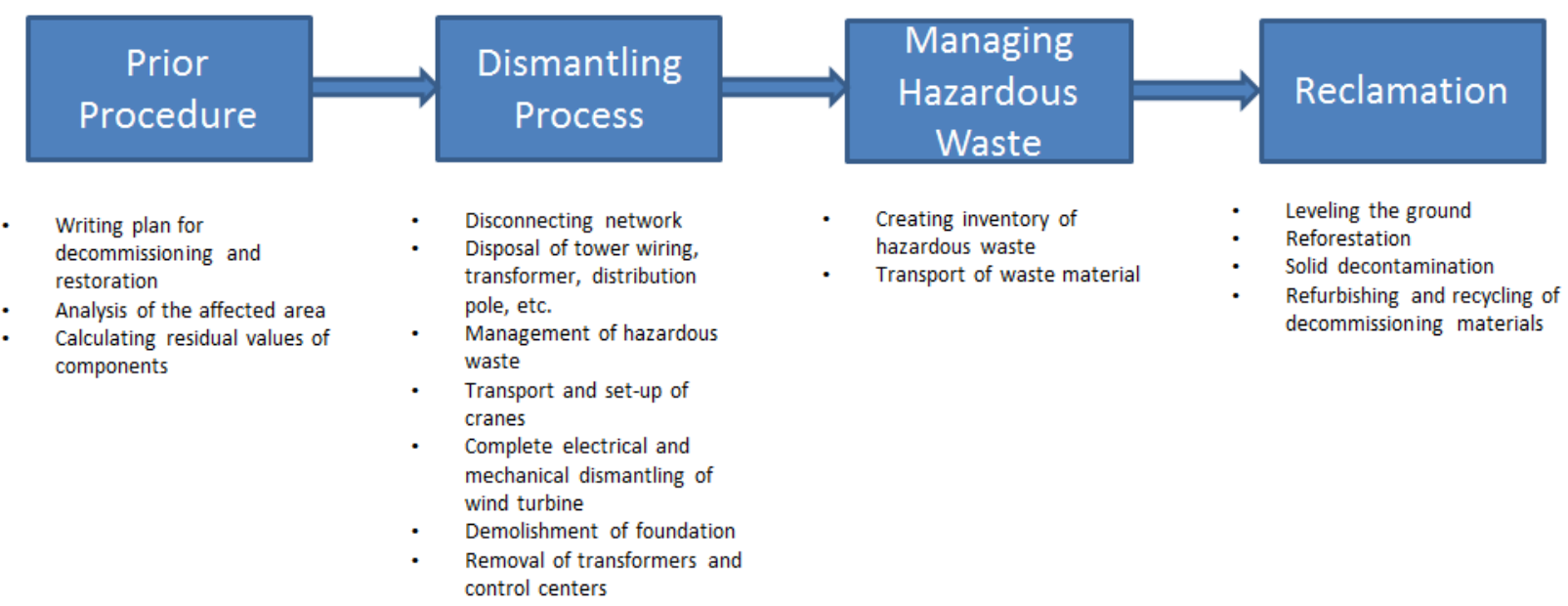

The cost of decommissioning is offset by the salvage value of the towers and the turbine components. The estimated cost of the Oakfield Wind Project, $\$ 1,425,000$, was calculated by subtracting the salvage value from the decommission cost (Table 5.4).

Table 5.4. Decommissioning cost of Oakfield Wind Project ${ }^{\mathrm{xxix}}$

\begin{tabular}{lccc}
\hline \multicolumn{1}{c}{ Category } & $\begin{array}{c}\text { Decommissioning } \\
\text { Cost [\$] }\end{array}$ & $\begin{array}{c}\text { Salvage } \\
\text { Value [\$] }\end{array}$ & Net [\$] \\
\hline $\begin{array}{lccc}\text { Project Management (contractor costs, equipment) } \\
\text { and O\&M building removal }\end{array}$ & $1,500,000$ & 0 & $1,500,000$ \\
Site work/Civil (site reclamation) & $1,070,000$ & 0 & $1,070,000$ \\
Wind Turbine Foundations & 420,000 & 0 & 420,000 \\
$\begin{array}{l}\text { Wind Turbine Generators (towers, hub, nacelle, } \\
\text { blades) }\end{array}$ & $1,901,000$ & $3,500,000$ & $(1,599,000)$ \\
Electrical Collector System & 529,000 & 500,000 & 29,000, \\
Substation & 199,000 & 194,000 & 5,000 \\
Generator lead transmission Line & 611,000 & 365,000 & 246,000 \\
\hline \multicolumn{1}{c}{ Total Minus Generator Lead } & $6,230,000$ & $4,559,000$ & $1,671,000$ \\
\hline
\end{tabular}

Some components of wind turbines are made of materials that can be easily recovered and have good scrap value such as steel and copper. However, blades are hard to recycle. ${ }^{295}$ Parts made out of

xxviii $\underline{\text { http://www.wsreclamation.com/category/wind-farms/ }}$

xxix

http://www.maine.gov/dep/ftp/WindPowerProjectFiles/Oakfield/Application/Volumes\%20I\%20and\%20II $\not$ Section\%2029.pdf 
steel or valuable metals are recycled since they are economically valuable. Blades made from fiberglass composite are difficult to the decommissioning process. So far information on the management of the wind turbine parts for their end-service life is lacking since the majority of wind turbines in operation in the United States have not met the end of their useful life. In general, the solid and industrial waste generated during the decommissioning and dismantling of the facility can be recycled and sold as scrap, or used in road building or bank re-stabilization projects. The remaining nonhazardous waste should be sent to disposal facilities. The nacelle and hub may be disposed in a designated landfill or may be processed to remove steel parts to sell as scrap. Blades and cable will be disposed of in a landfill. Towers will be dismantled and sold as scrap steel. Refurbishing and reusing turbine components, power cables, foundations and transition pieces are not suitable due to the age of the components at the time of removal and heavy wear and tear during their lifetime. ${ }^{296}$ Steel, copper, aluminum, and copper are sold as scrap for recycling. Blades are cut into smaller pieces and are then further crushed, shredded, and milled down. Cables and electronic equipment are delivered to a recycling company that separates them into metals for recycling, plastics for energy recovery, and toxic materials for disposal.

One windfarm that was decommissioned in southwestern Australia consisted of six $60 \mathrm{~kW}$ turbines. This farm began in 1987 and operated for 15 years. ${ }^{297}$ It was decommissioned since aging turbines and advancements in technology made building new wind plants more cost effective than retrofitting old wind plants. In the United States, some wind farms have been abandoned. This was the case for Kamaoa, a wind farm in South Point, Hawaii, and Tehachapi wind farm in Southern California. While Kamaoa was decommissioned by Apollo energy in 2012, some abandoned wind turbines remain around the Tehachapi area. ${ }^{298}$

There is limited information about material recycling issues from wind farm repoweringxxx. BLM currently has clear decommissioning guidelines in place for facilities located on BLM lands, but there are currently no guidelines for facilities located on private lands. With advancements in technology, repowering wind turbines with new upgrades will improve the energy efficiency these new turbines can achieve. In California, the wind turbines that were built in the 1980s and the 1990 s represent the primary opportunity for repowering in the United States ( $2 \mathrm{GW})$. However, this has been limited due to policy and regulatory factors. ${ }^{\text {xxx }}$ Some of the potential benefits of repowering wind turbines are increasing renewable energy production due to higher capacity factor, using existing infrastructure such as roads, substations resulting in lower installation costs, and using new technology that can better support electrical grid with better power quality.299.xxxii xxxiii

\subsection{SOLAR}

Solar power in the United States consists of utility-scale solar power plants and local distributed generation. Over the past several years, there has been a significant growth in small scale

\footnotetext{
xxx http://www.windpowermonthly.com/article/1124486/complexities-recycling-begin-bite xxxi http://www.nrel.gov/docs/fy15osti/63591.pdf

xxxii http://www.energy.ca.gov/2008publications/CEC-300-2008-004/CEC-300-2008-004.PDF

xxxiii http://www.windpowermonthly.com/article/963892/repowering-projects-completed
} 
distributed solar photovoltaic (PV) systems (residential and commercial rooftop) and further growth is expected in the coming years in part as a result of the recently extended investment tax credits for solar that were recently extended.

Another type of solar PV system is concentrating solar power (CSP); it has the capability to deliver reliable energy to hundreds of thousands of customers. Depicted in Figure 5.4, total solar

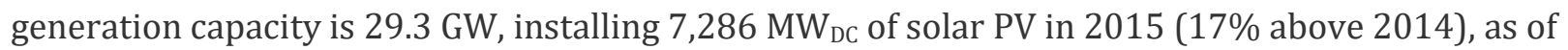
Q1 2016 in the United States. ${ }^{300} 301$ The residential solar market now represents $20 \%$ of the total American solar market, while utility scale solar PV represents over half of the all solar PV installed in 2015 (Figure 5.5). $110 \mathrm{MW}_{\mathrm{AC}}$ of CSP capacity was added in late 2015 with the start of SolarReserve's Crescent Dunes Project.

There are various types of solar PV. Polycrystalline solar cells, also known as polysilicon, are much more affordable, and operate at 13-16\% efficiency. They are less space efficient, but have a lower heat tolerance than monocrystalline. Thin film solar cells have an efficiency typically of 7-13\%. By $2011,5 \%$ of the solar cells in market were thin film solar cells. Due to ongoing research, it is expected to achieve efficiency of $16 \%$ in the coming models. They require a great deal of space, which makes them difficult for residential applications since rooftop space is usually at a premium. Cadmium telluride solar cells can be cost effective in certain markets, and their efficiency is in the range of 9 to 11\%. Copper Indium Gallium Selenide (CIGS) Solar Cells are similar to crystalline technologies in terms of efficiency (10-12\%) 302 $^{2}$ and are mostly used for larger applications. These are still in the nascent stages of research and are not widely deployed on a commercial scale. 
Figure 5.5. American Solar PV Installations ${ }^{303}$

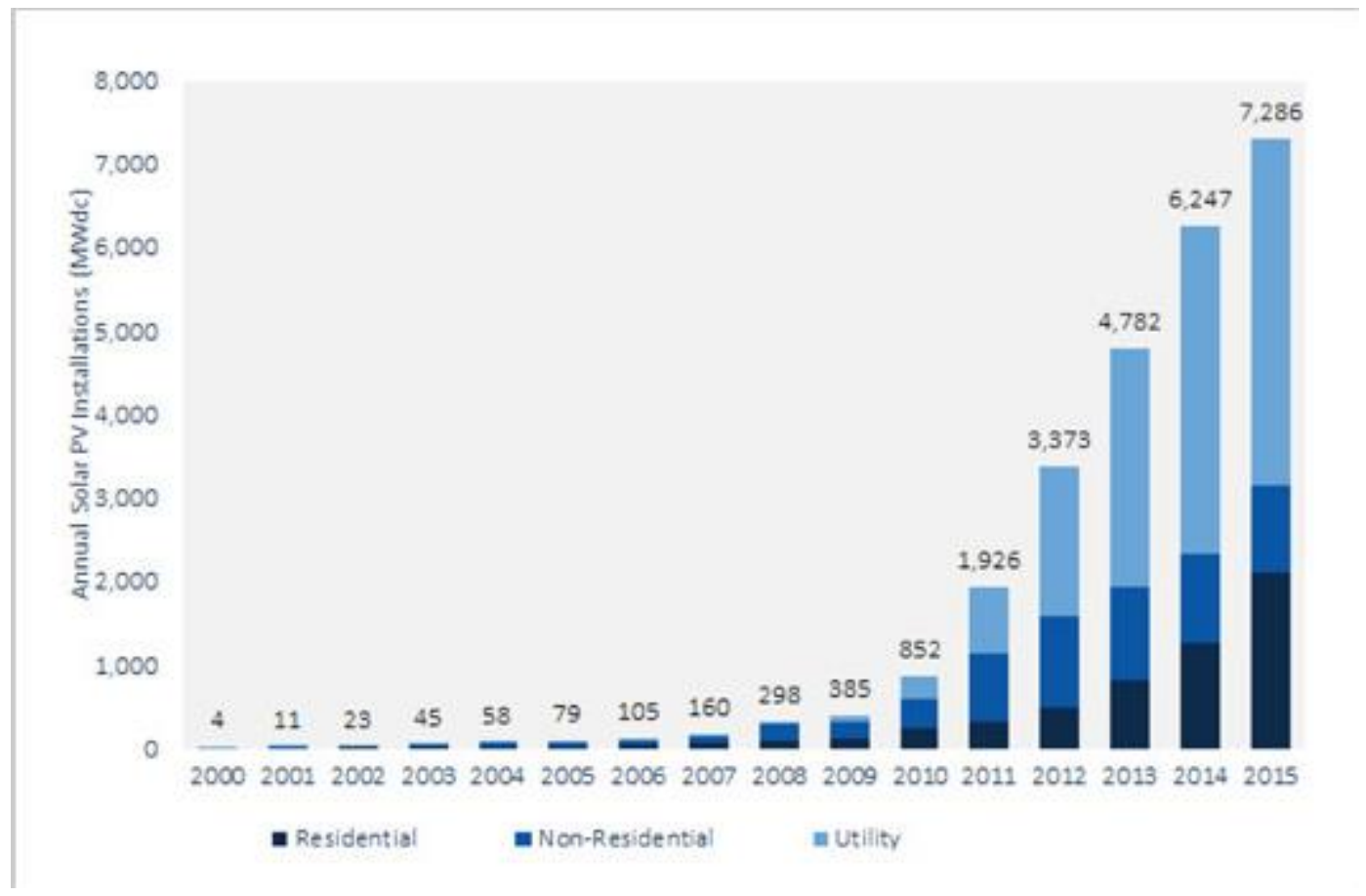

Figure 5.6. Share of American PV Installations by Segment ${ }^{304}$

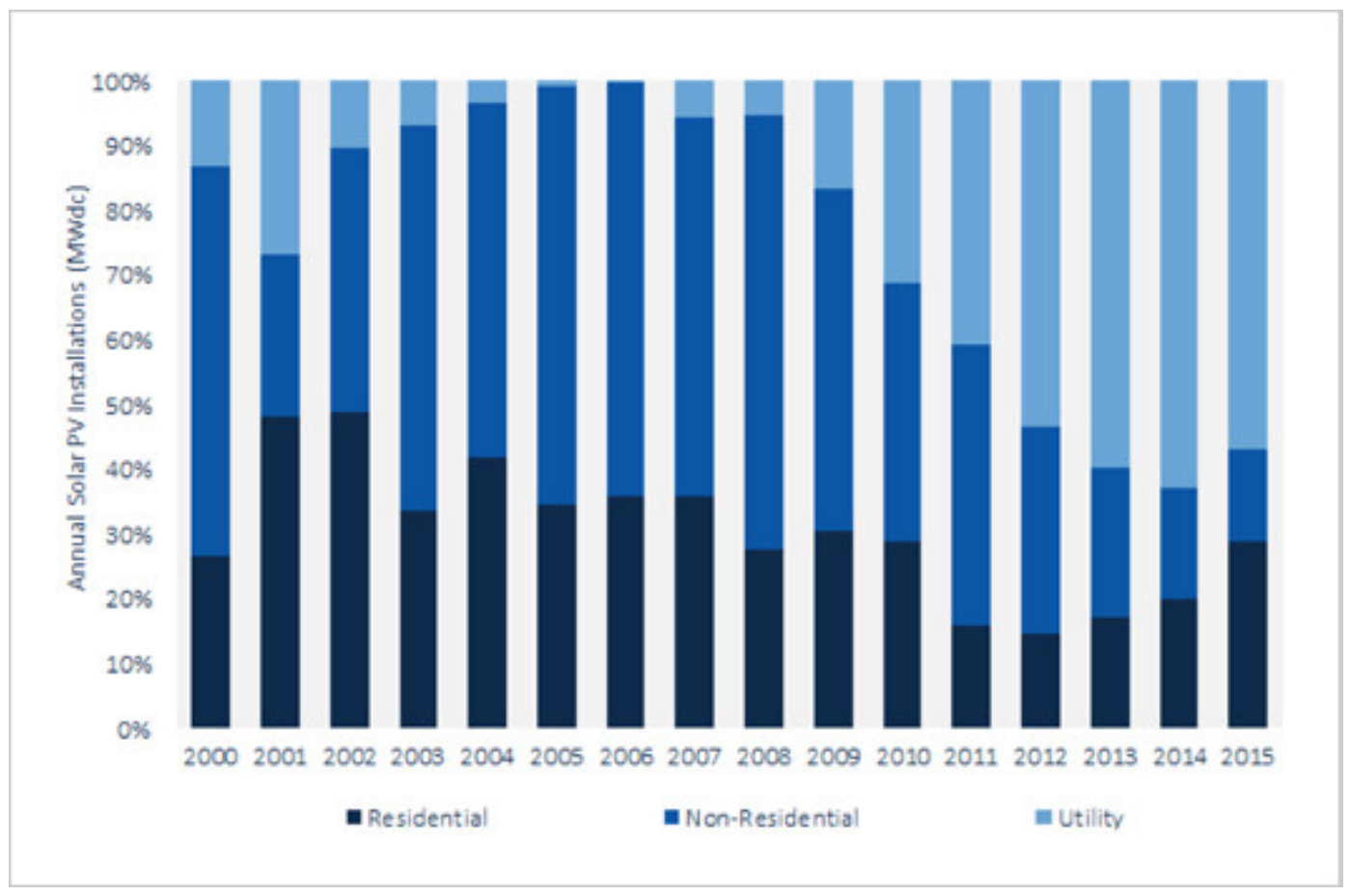




\subsubsection{Regulations}

The main components of solar panels are steel, concrete, glass, and copper which do not pose any threat to the surroundings. Numerous regulations oversee manufacturing chemicals and materials, and disposal of PV components such as Toxics Release Inventory (TRI), Materials Safety Data Sheets (MSDSs), Resource Conservations and Recovery Act (RCRA), and Toxicity Characteristic Leaching Procedure (TCLP) standards. There are no standard regulations for decommissioning of solar PV, similar to wind projects (Figure 5.6). Different states have their own regulations, refer to Section 5.3.1. Similar to wind projects, the applicant shall submit a decommissioning plan for review and approval as part of the commissioning application. The decommissioning plan shall identify expected life of the project, method and physical process for removing all components, returning the site to its pre-existing condition, and an estimate of decommissioning costs including salvage value. Majority of the solar panels are expected to reach their end-of-life over the next few decades. In the United States, there is no state or federal regulation to recycle its components. ${ }^{305}$ However, there are several solar companies coming up to recycle on a voluntary basis. Some manufacturers offer end-of-life recycling options. This allows for the recycling of the PV panels and prevents issues with the hazardous materials. Many solar companies are looking into recycling concerns not only in the United States, but globally. For example, PV Cycle, a European-based voluntary agreement, assists in recycling PV modules after they retire.

The Federal Resource Conservation and Recovery Act (RCRA), and state policies govern waste and disposal of solar products when it reaches end-of-its life. RCRA only governs hazardous waste that cannot pass the Toxicity Characteristics Leach Procedure test (TCLP). The majority of solar panels are not harmful, and thus are not regulated by RCRA. 
Table 5.5. Summary of State Solar Decommissioning Policies ${ }^{306}$

\begin{tabular}{ll}
\hline \multicolumn{1}{c}{ States } & \multicolumn{1}{c}{$\begin{array}{c}\text { Renewable Facility Decommissioning } \\
\text { Rules/Fund }\end{array}$} \\
\hline CA, HI & $\begin{array}{l}\text { Statewide decommissioning rules and } \\
\text { financial security requirement xxivunder } \\
\text { certain circumstances. }\end{array}$ \\
\hline NJ & $\begin{array}{l}\text { Statewide decommissioning rules apply } \\
\text { under certain circumstances. No requirement } \\
\text { to provide financial security. }\end{array}$ \\
\hline WA & $\begin{array}{l}\text { Statewide optional certification process. } \\
\text { Includes site restoration and financial } \\
\text { security requirements. }\end{array}$ \\
\hline LA, NE, NH, OK, VT & $\begin{array}{l}\text { Statewide requirement to submit a } \\
\text { decommissioning plan under certain } \\
\text { circumstances. }\end{array}$ \\
\hline VA & $\begin{array}{l}\text { No statewide policy; local government } \\
\text { ordnances that address solar siting must } \\
\text { address decommissioning. }\end{array}$ \\
\hline AL, AK AR, AZ, CO, CT, DC, DE, FL, GA, IA, ID, & No statewide policy, local government \\
IL, IN, KS, KY, MA, MD, ME, MI, MN, MO, MS, & authority. \\
MT, NC, ND, NM, NV, NY, OH, OR, PA, RI, SC, & \\
SD, TN, TX, UT, WI, WV, WY & \\
\hline
\end{tabular}

\subsubsection{Decommissioning}

During decommissioning, PV modules must be removed from racks, and the racks must be dismantled. These are stored temporarily on-site until they are transferred by trucks to appropriate facilities like recycling sites or back to the manufacturer. Similarly, inverters and associated components must be transported to an appropriate site. All solid and hazardous waste should be disposed as per local, state, and federal waste disposal regulations. Finally, re-vegetation of the site is done to minimize erosion and disruption of vegetation.

The manufacturing process of PV cell includes hazardous materials such as hydrochloric acid, sulfur acid, nitric acid, hydrogen fluoride, 1,1,1-trichloroethane, and acetone. Depending on the type of and size of silicon wafer, the amount of chemicals used varies. Thus, it is important to dispose of waste products properly. If these materials are not handled and disposed of properly, it could result in serious environmental threats. However, manufacturers receive strong financial incentive to ensure that materials are recycled properly. 307

In the Apple One Solar Farm Decommissioning Plan, an estimated decommissioning cost was provided. ${ }^{308}$ The total projected site demolition cost is $\$ 560,920$, the projected site restoration cost is $\$ 18,000$, and the projected salvage value is $\$ 1,019,300$. Thus, the projected new decommissioning cost is $-\$ 440,380$. This means that the recycling value of the raw material for the solar array will exceed the removal costs and provide a net gain. 
Table 5.6. Projected Site Decommissioning Cost ${ }^{309}$

\begin{tabular}{lcccc}
\hline \multicolumn{1}{c}{ Task } & Unit Price [\$] & $\begin{array}{c}\text { Estimated } \\
\text { Quantity }\end{array}$ & Total [\$] & Grand Total \\
\hline Fence Removal & 13.00 & 6,545 & $85,085.00$ & $\$ 560,922.50$ \\
Racking frames & 500 & 595 & $297,500.00$ & \\
Racking posts & 6.50 & 2,975 & $19,337.50$ & \\
Solar Panels & 4.00 & 22,600 & $90,400.00$ & \\
Inverters & $1,500.00$ & 8 & $12,000.00$ & \\
Transformers & $1,200.00$ & 8 & $9,600.00$ & \\
Wire (Copper) & 0.50 & 10,000 & 5,000 & \\
Wire (Aluminum) & 0.50 & 18,000 & 9,000 & \\
Concrete removal & 6.00 & 5,500 & 33,000 & \\
\hline
\end{tabular}

Table 5.7. Projected Salvage Value ${ }^{310}$

\begin{tabular}{lcccc}
\hline Task & Unit Price [\$] & $\begin{array}{c}\text { Estimated } \\
\text { Quantity }\end{array}$ & Total [\$] & Grand Total \\
\hline Steel Racking Posts: 2,975 posts @ 60 & 0.16 & 178,500 & $28,560.00$ & $\$ 1,019,303.50$ \\
lbs & 0.87 & 728,280 & $633,603.00$ & \\
Aluminum Racking: 595 Racks @ & 0.15 & 31,600 & $4,740.50$ & \\
19.5M & 14.00 & 22,600 & $316,400.00$ & \\
Fencing & $2,500.00$ & 8 & $20,000.00$ & \\
Solar Panels & $2,000.00$ & 8 & $16,000.00$ & \\
Inverters & & &
\end{tabular}

The lifetime of an inverter is approximately 10 years, and it is recommended to replace a solar inverter that is over 10 years old with a new inverter. This is because the cost is quickly recovered by much higher yield. However, there is not much information on how many solar inverters have been replaced so far, or if they have been any recycling or disposal issue.

\subsubsection{Recycling}

As the solar installations in the United States grow, the industry is planning ahead to create recycling programs. Solar Energy and Industries Association (SEIA) members are working on developing recycling processes for the solar industry and federal regulations that support safe and effective recycling models. ${ }^{\mathrm{xxx}}$

Deustche Solar and First Solar are two companies that implement recycling processes for their solar panels.xxxi First Solar has implemented a recycling program and has been able to reduce its

xxxv http://www.seia.org/policy/environment/pv-recycling

xxxvi http://www.firstsolar.com/en/Technologies-and-Capabilities/Recycling-Services 
manufacturing cost by retrieving materials from its damaged and scrap modules. Deutche Solar's recycling process for the recycling of crystalline silicon panels was designed in 2003.311 Plastic components are separated from the panel through a thermal process, while the remaining parts are removed manually. Once the components like glass, aluminum, steel, etc., are separated, they are sorted and placed into their respective recycling processes.

The PV modules can be divided into three components: metal, glass, and silicon wafers. The metal and glass can be recycled using the current recycling infrastructure, while silicon wafers can be processed into new solar cells using standard solar cells production processes. Efficiencies of reprocessed monocrystalline cells range from $15 \%$ to $16.4 \%$, and reprocessed polycrystalline cells have efficiencies ranging from $12.7 \%$ to $15.9 \%$. These efficiencies increased from the original levels due to improved cell processing technology. Using silicon wafers reclaimed from end-of-life PV to create new solar cells is a viable recycling method due to an increase in efficiency because of improved cell processing technology.xxxvii

First Solar's treatment process for their CdTe panels was developed in the late 1990s and was established in 2003. First Solar can recover $90 \%$ of the glass and $95 \%$ of the semiconductor materials and reuse these in new PV panels. However, due to the lack of panels at their end-of-life, the recycling process is mainly used for recovering materials from broken panels or manufacturing scraps. ${ }^{312}$

xxxvii http://2011.solarteam.org/news/recycling-methods-for-used-photovoltaic-panels 
Figure 5.7. Recycling Process ${ }^{x x x v i i i}$

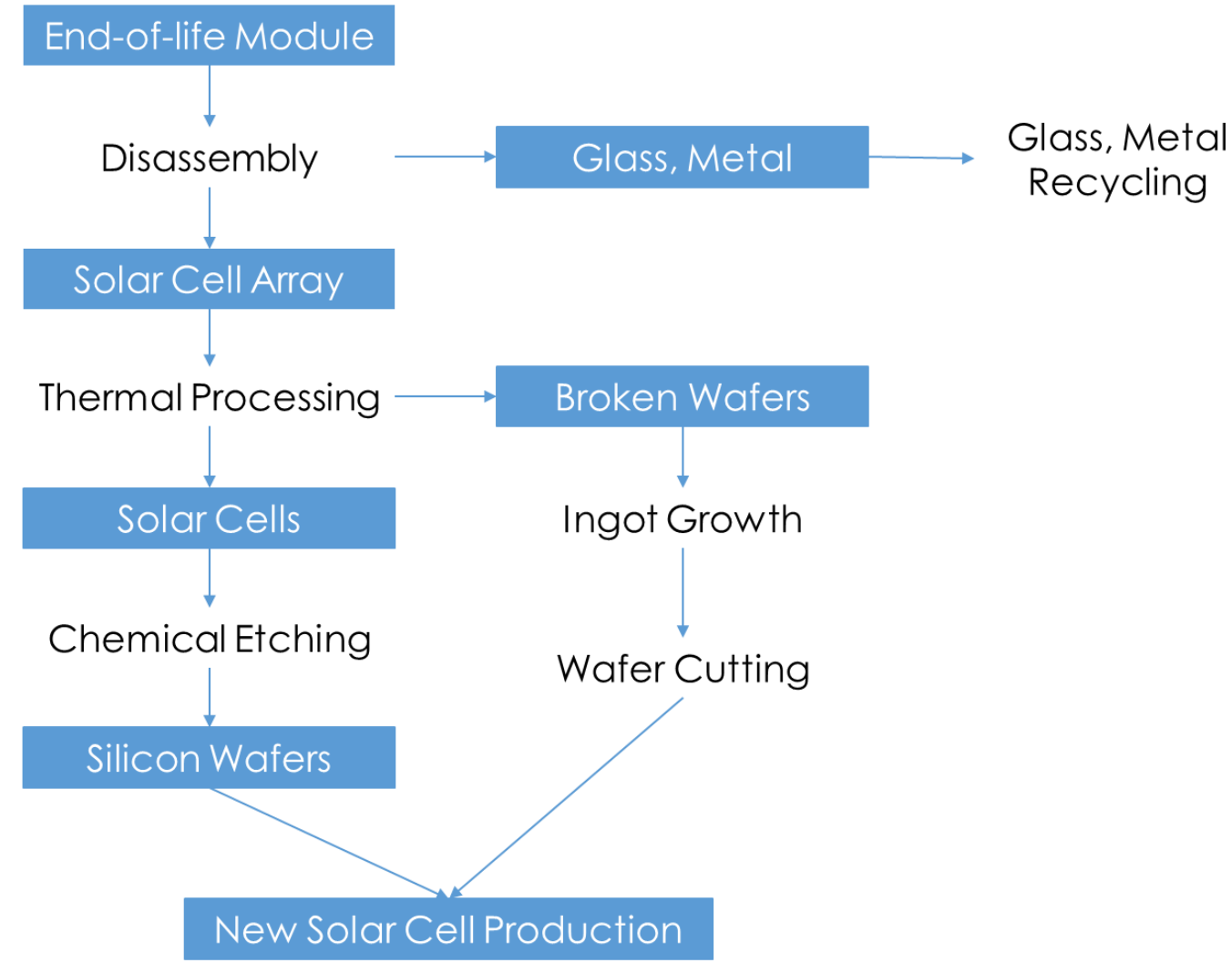

\subsection{CONCLUSIONS}

Renewable energy, especially solar and wind, is a clean energy source and is expected to grow rapidly in the coming years. Growth in the development of new and expanded hydropower plants has been slow in part because of changes in hydropower regulations and electricity markets. However, with increased interest in the renewable industry, hydropower plants are receiving attention once again. The partnership between government and non-government entities across the Dams Sector has resulted in the development of a variety of tools and products focused on improving protection and enhancing resilience. The environmental considerations for dam removal are fish habitat restoration, wetland creation and loss, and sediment release. The economic issues for decommissioning a dam are related to improving an aging dam. Dam removal projects have previously ranged from $\$ 50,000$ to $\$ 400,000$ in total costs.

The majority of wind turbines and solar systems in operation in the United States today have not met the end of their useful lives. As a result, there is limited information on the decommissioning of these power generation facilities since most of them have not yet reached the end of their 20-30 life expectancy. In the case of solar and wind power, there are no state or federal regulations in the

xxxvii http://2011.solarteam.org/news/recycling-methods-for-used-photovoltaic-panels 
United States to recycle its products. There are no standard procedures to decommission wind and solar plants.

As a result, many questions about solar and wind power remain. What metals and semiconductors are recycled, what percent of the solar panels/wind turbines can be recycled, and what happens to solar inverters after their 10-year life expectancy ends? To summarize, the wind and solar industry are still in the early years of development and significant decommissioning activity is not expected for decades. Nevertheless, addressing these issues early can help avoid decommissioning problems later. 


\section{OVERVIEW OF COMMON WASTES AND DECOMMISSIONING PROCEDURES FROM THE ELECTRICITY SECTOR}

The common waste streams produced by the decommissioning, demolition, and retirement of different types of power plants are described in this chapter. Most nuclear and fossil-fueled power plants have common features such as powerhouse equipment, buildings and structures, transmission towers, power electronics, and transport infrastructure to receive and deliver supplies. Some of these same features are present at hydro, wind, and solar plants, as summarized in Table 1.3.

Fuel storage and waste streams from energy resources tend to be more particular to different types of energy technology and fuel systems as discussed in previous chapters. For example, coal-fired power plants produce coal ash and scrubber slurries, while nuclear power plants produce low- and high-level nuclear waste. Most renewables produce minimal solid waste during their operational phase, but upon retirement, they have end-of-life waste products such as power electronics and T\&D equipment and devices that are common to most electricity generating technologies. These solid wastes are described in this chapter.

\subsection{FACILITY MATERIALS}

\subsubsection{Construction Materials}

Much of the brick, concrete, and metal used to build structures at power plants can be recycled, even from nuclear power plants since most of these materials do not become radioactive. ${ }^{313}$ While the sorting and recycling aspects of plant decommissioning can be unique to different electricity technologies and fuels, much of it is common. Indeed, the volume of common solid waste from retired electricity generation facilities is rapidly growing. However, public information sources describing the extent of this recycling activity are not available.

The U.S. is in the process of handling a rapid and large influx of materials from retired power plants, such as concrete, brick, and metal. New infrastructures for recycling materials and reusing parts could help manage this influx of solid waste from the growing number of retired power plants.

To illustrate the magnitude of the solid waste challenge facing the electricity industry, consider the steps taken by AEP to dismantle its long-idled Tidd Coal Plant in Ohio, and to take advantage of opportunities to recycle its concrete and brick. A large excavator/shearer machine, one of the largest of its type in the world, was used to tear down the structure (Photo 6.1). Workers at the Tidd Coal Plant ground up the material, so that it could subsequently be used to backfill the facility's basement. This saved AEP the expense of hauling and disposing of this material, and of having to bring in other backfill material. ${ }^{314}$ 
Photo 6.1 Demolition of the Fluidized Bed Coal Combustor Building at the Tidd Plant ${ }^{315}$

A large excavator/shearer machine

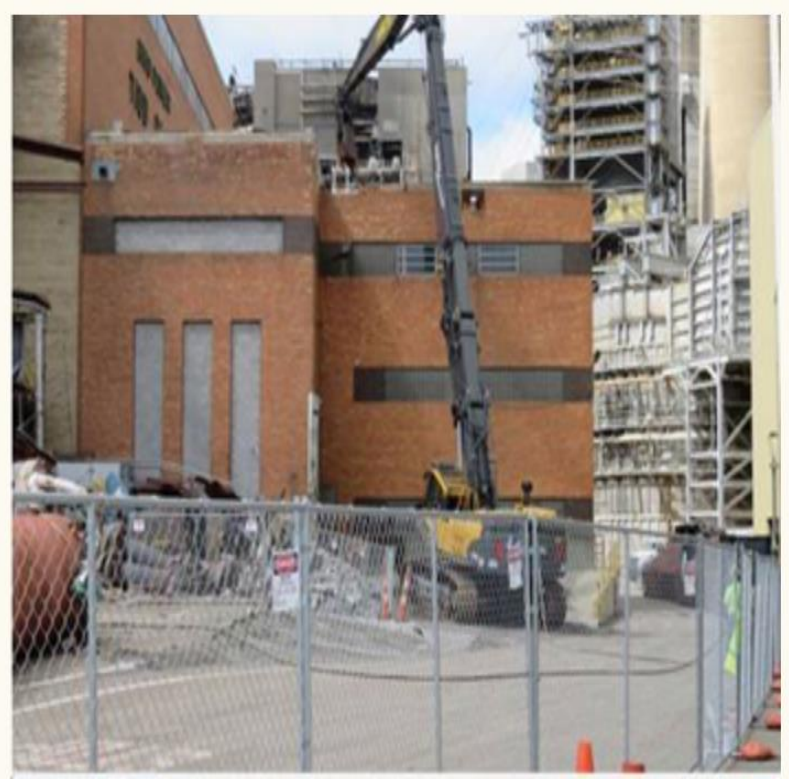

Sorting and hauling away debris

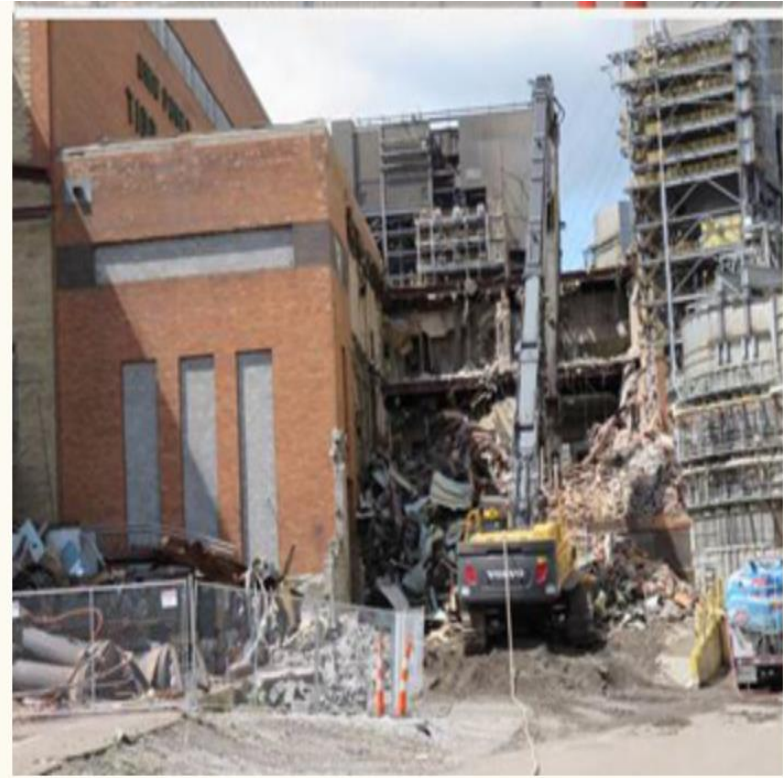

As with most plant demolition projects, The Benning Road power plant demolition in Maryland was able to harvest electrical busbar, connectors, condenser tubes, wire, copper and building steel, providing a $\$ 7.7$ million credit. ${ }^{316}$ Photo 6.2 shows some of the effort required to sort through such large-scale waste.

Photo 6.2. View of Salvage Operations to Harvest Non-Ferrous and Ferrous Material Following Power Plant Demolition ${ }^{317}$

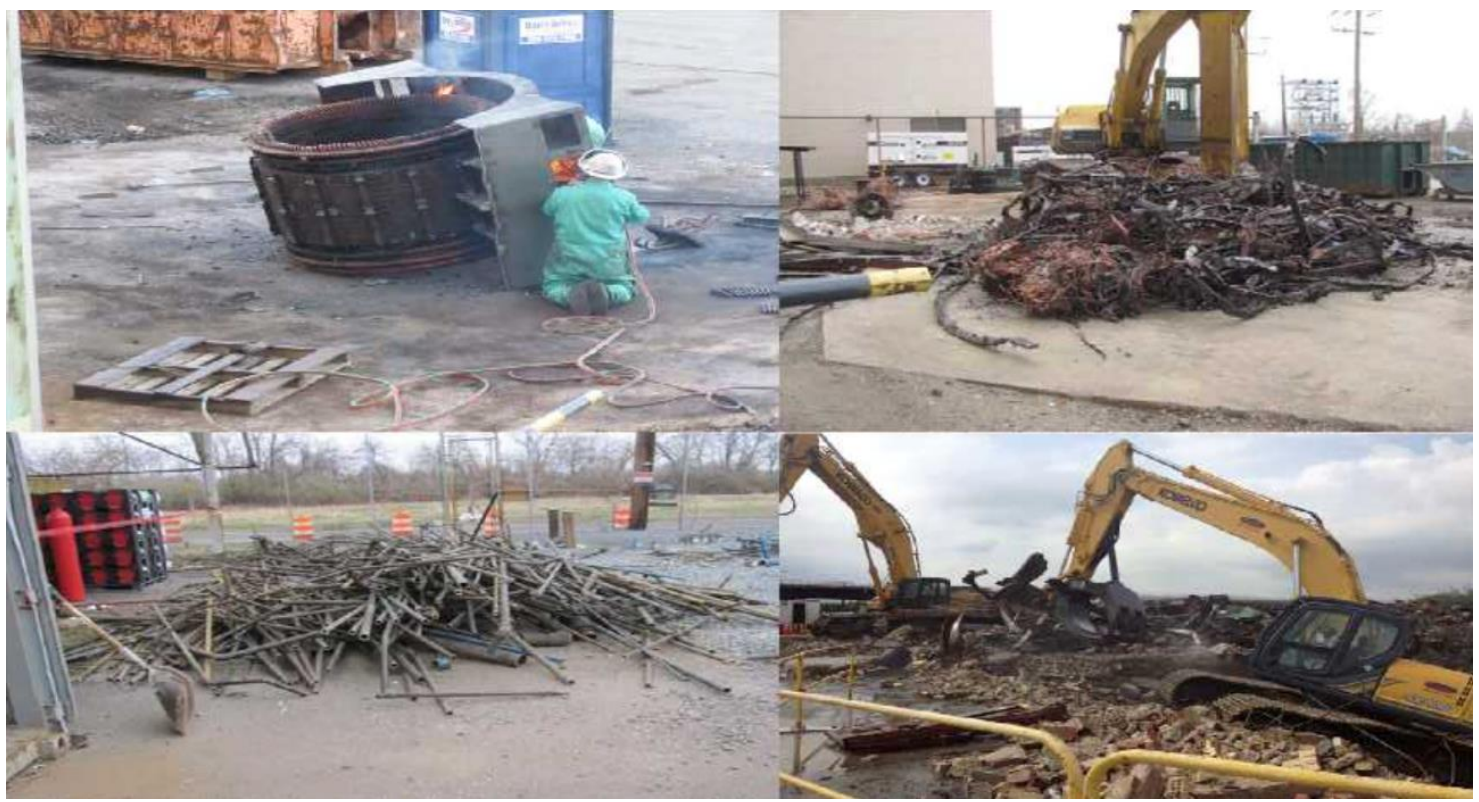


Industrial wastes like lubricating oils, hydraulic fluids, dielectric fluids, coolants, solvents, and cleaning agents are managed just as maintenance wastes are treated during operation: they are put in containers, characterized and labeled, stored briefly and transported to an appropriate off-site disposal facility by a licensed hauler. Their disposal must comply with numerous regulations. Impacts could be serious if these wastes are not properly handled and are released to the environment. Several specific toxic waste streams are highlighted below.

\subsubsection{Asbestos}

Power plant decommissioning has the potential to produce hazardous wastes if the property has asbestos. The Asbestos National Emission Standards for Hazardous Air Pollutants (NESHAP) regulations specify work practices for asbestos to be followed during demolitions and renovations of all structures, installations, and buildings. ${ }^{318}$ The regulations require the owner of the building or the operator to notify the appropriate state agency before any demolition, or before any renovations of buildings that could contain a certain threshold amount of asbestos or asbestoscontaining material. The demolition cannot emit visible emissions into the outside air and must follow air cleaning procedures and other requirements when removing asbestos-containing waste (Photo 6.3). ${ }^{x x x i x}$ Asbestos is typically left at the plant and is inspected and maintained until removal with the demolition of relevant structures. ${ }^{319}$

Asbestos management can be challenged by poor record keeping. Some structures are found to have asbestos only after decommissioning has begun. Also, many structures within a plant cannot be tested until the plant is fully powered down (such as those surrounding boilers, turbines, and heat recovery units), adding risk to the decommissioning project.

Asbestos from decommissioned power plants is usually transferred to an asbestos landfill. ${ }^{320}$ There are multiple asbestos landfills in nearly every state. ${ }^{321}$

\section{Photo 6.3. View of Asbestos Containment Area During Demolition ${ }^{322}$}

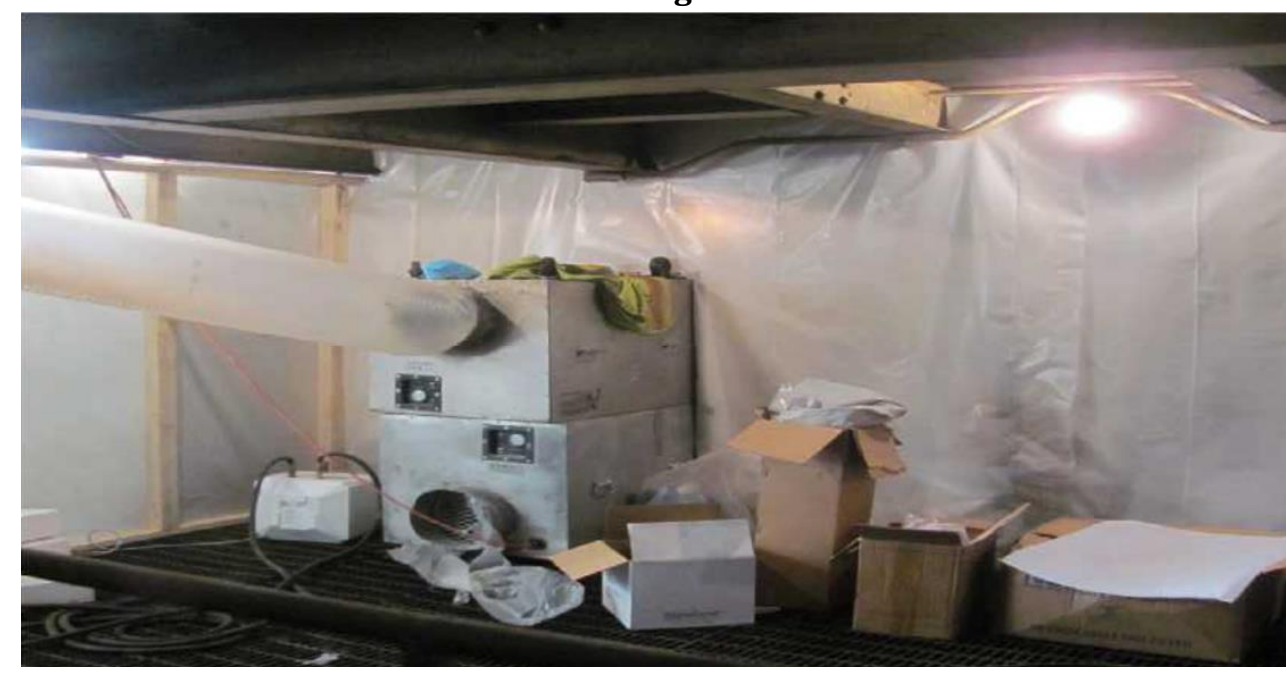

xxxix The photos are from EPA: http://www.epa.gov/asbestos/asbestos-laws-and-regulations 


\subsubsection{Lead}

The demolition of buildings has the potential to produce hazardous wastes if the property has leadbased paint (LBP). LBP was widely used on buildings before 1978 when it was banned from residential structures by the Consumer Product Safety Commission. Prior to the 1950s, paints contained as much as $50 \%$ lead by weight. Lead is a pollutant regulated by many laws administered by EPA, including the Toxic Substances Control Act (TSCA), Residential Lead-Based Paint Hazard Reduction Act of 1992 (Title X), the Clean Air Act (CAA), and the Clean Water Act (CWA), among others. ${ }^{323}$ Because whole-building demolition debris is not likely to exceed the toxicity characteristic standard for lead (assuming it is handled as a single, whole waste stream), some of these regulations do not apply to the total demolition of a structure. Thus, there does not have to be remediation of the ground after demolition due to contamination from paint, unless the site is being prepared for re-use.

Lead-safe work practices can minimize lead-based paint exposure via the dust and debris generated during demolition activities. These practices include:

- containing dust inside the work area

- using dust-minimizing work methods

- conducting a careful cleanup during the demolition..$^{324}$

At a minimum, surfaces are typically wetted when possible to control the spread of leaded dust into the air, as shown in Photo 6.4.

Photo 6.4. Management of Dust During Demolition ${ }^{325}$

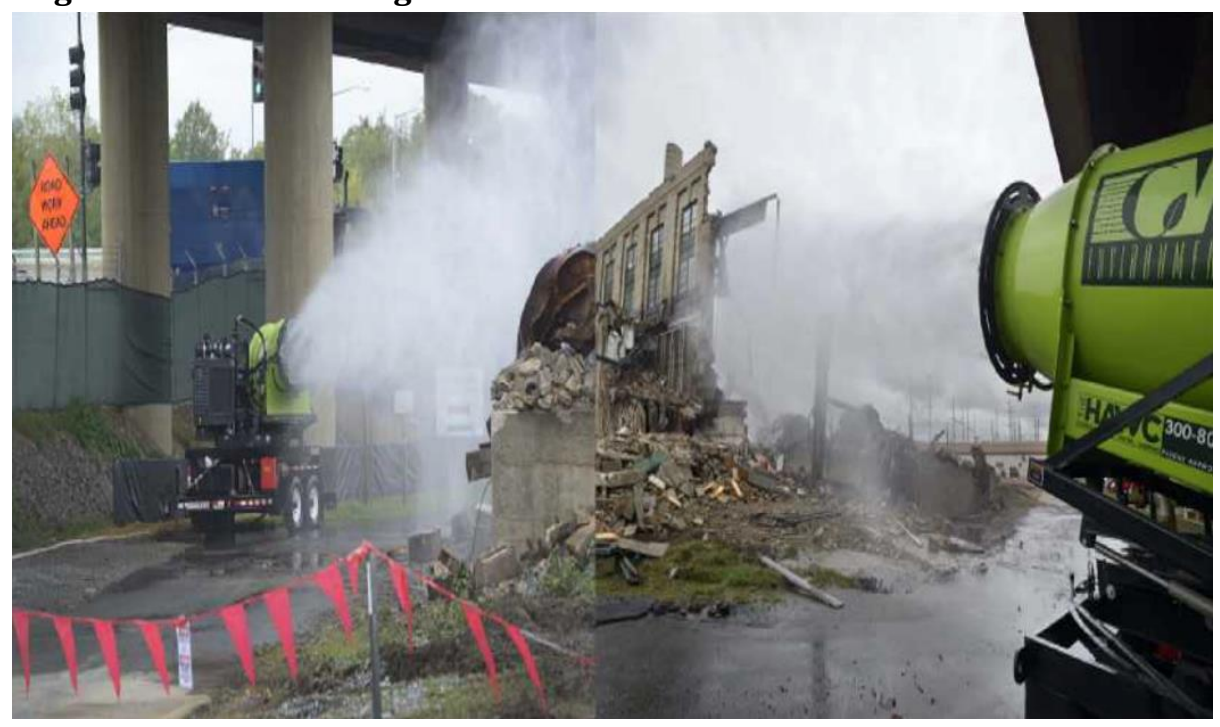




\subsection{POWER ELECTRONIC WASTES}

\subsubsection{Polychlorinated Biphenyls (PCBs)}

Polychlorinated biphenyls (PCBs) are a class of toxic chlorinated compounds (known as congeners) that are either oily liquids or solids. These chemicals are widely used in the utility industry as dielectric fluids in transformers and capacitors, as hydraulic fluids, and in fire-retardant materials. Capacitors are passive elements in a power converter that use PCBs because of their excellent dielectric properties and low flammability. However, when burned they release toxic chemicals with well documented harmful effects on human health, and they are not readily biodegradable. Small quantities of PCBs are used in capacitors in fluorescent lamps, in electric motors, in magnets, and in larger quantities in devices such as power factor correction units. As a result, countries began eliminating PCBs from power electronics in the 1980s, and the United Nations Environmental Program (UNEP) is attempting to eliminate the use of PCBs entirely by 2025.326

Because of their adverse health effect, the Toxic Substance Control Act (TSCA) banned the production of PCB after 1978 [Section 6(e)]. The disposal of every piece of equipment or material containing more than $50 \mathrm{ppm}$ of PCB must be handled according to the standards outlined in TSCA (40 CFR 761.60). In certain circumstances, wastes with a PCB concentration of $<50$ ppm must also meet the disposal requirements of 40 CFR 761. PCB wastes with a PCB concentration $>50 \mathrm{ppm}$ must be disposed of in a TSCA incinerator, TSCA chemical waste landfill, or by an EPA-approved alternative method. ${ }^{327}$ Even during temporary storage and shipment, compliance with regulations must be maintained. ${ }^{328}$ About 60 commercial storage facilities throughout the country have been approved under 761.65 (d). Among these facilities are ten chemical waste landfills, eight scrap metal ovens, seven incinerators, five chemical dechlorination facilities, four fluorescent light ballast recycling facility, and one PCB electrical cable processing plant for metal recovery. ${ }^{329}$

\subsubsection{Other Toxic Waste from Power Electronics}

Power electronics are a growing feature of electric systems, including uninterruptible power supplies (UPS), transformers, fault current limiters, circuit breakers, metal oxide semiconductor field effect transistors (MOSFETS), insulated gate bipolar transistors (IGBTs), and Flexible Alternating Current Transmission System (FACTS) devices. High voltage power electronics, such as switches, inverters, converters, and controllers, allow electric power to be precisely and rapidly controlled to support long-distance transmission. Such equipment also allows the system to respond effectively to disturbances and to operate more efficiently, thereby reducing the need for additional infrastructure. ${ }^{330}$

Power electronics are often embedded in structural blocks that are "difficult to recycle, expensive, polluting and with a low profitability and low recovery of materials....".331 The printed circuit board is an example. It is an essential component of power electronics, providing the physical structure for mounting components and electrical interconnections. Tin-lead solder is an alloy of tin that is used almost exclusively in the electronics industry because of its low cost and high reliability. However, lead is a neurotoxin. As a result, it is being replaced by lead-free alloys, but its damage is 
already significant: much of the lead found in landfills comes from waste electrical and electronic equipment.

Circuit boards also have plastic covers that use brominated fire retardants, which are considered neurotoxic. A European Union directive and California state law ban the use of two types of these retardants (pentaBDE and OBDE). ${ }^{332}$ Another carcinogenic element, cadmium, is used in printed circuit boards to prevent oxidation. ${ }^{333}$

With the combination of lead, brominated fire retardants, and cadmium use in printed circuit boards, the further disposal of circuit boards in landfills could cause significant environmental risk. Given the proliferation of increasingly smart machinery and devices at power plants and elsewhere, this trend is concerning.

\subsection{CHAPTER CONCLUSIONS}

With the growing number of retired power plants in the United States, solid waste from power plant decommissioning, demolition, and retirement is increasing. Some common construction materials, including concrete, bricks, and metals, are being recycled during decommissioning, as described anecdotally in this chapter. However, public information sources describing the extent of this recycling activity from construction materials and power plants is not available.

This chapter highlights the management of asbestos, lead-based paint, and toxic waste from power electronics. While numerous regulations oversee the management of these wastes, the large-scale demolition of buildings and structures has the potential to release significant amounts of these hazardous wastes. Once solid wastes are placed into landfills, incinerators, and other disposal sites, it is difficult to retrieve or re-use them. Such is the case with the disposal of circuit boards and other e-waste, which could pose significant environmental risk. While efforts are underway to manage ewaste, ${ }^{334}$ currently, these devices with toxic substances that are essential to power plant operations are not regulated and are disposed as untreated e-wastes in landfills. 


\section{LOCAL ECONOMIC AND COMMUNITY IMPACTS OF RETIREMENTS}

\subsection{ECONOMIC IMPACTS}

The local economic impacts of retiring large conventional power plants are significant, complex, and not well documented. Economic impacts of decommissioning tend to be more pronounced in remote communities where power plants can be a dominant driver of the economy. ${ }^{335}$ Both nuclear and coal facilities are often placed far from population centers for safety and environmental reasons. As a result, the host rural communities have often grown to serve the needs of power plants and their workers. Businesses and schools expand and shrink in proportion to the power plant workforce. While the influx of decommissioning contractors may briefly stimulate the local economy, ${ }^{336}$ decommissioning coal and nuclear plants ultimately increase unemployment rates in host communities if the legacy site is not repurposed with a comparable job-generating activity. ${ }^{337}$

Property values in local communities with a retiring plant typically decrease with population outmigration. Young, well-trained employees are typically the most likely to relocate in their search for work. The community may also be required to find new sources for some services that were part of the power plant's supply chain, and if there is a decrease in overall payrolls as well as the property tax base, tax revenues and public services will also decrease. ${ }^{338} 339$ The lands surrounding the power plants may become devalued if the plant site is considered "damaged." 340 However, if the site is restored, demand and prices for the land may increase. However, many of these negative impacts would be potentially mitigated from the opening of a new power plant utilizing a different energy source. 341

For nuclear plants, the choice of DECON, SAFSTOR, or ENTOMB will affect communities differently. ${ }^{342}$ For coal plants, the choice between minimal demolition and idling versus full decommissioning will also have differential impacts. In general, the decommissioning phase could result in creating new jobs for workers. Indirect impacts would be created at businesses that support the decommissioning workforce or that provide project materials and associated income and taxes. In the long term, loss of jobs and revenue after decommissioning is complete would adversely impact the local and regional economies if repurposing does not occur. ${ }^{343}$ The impacts will depend on the nature of the decommissioning activity. ${ }^{344}$ As a result, plant managers must walk a tightrope between what is most economical for the plant and what is most economically advantageous for the surrounding community. $345 \mathrm{xl}$

During decommissioning, human health and safety risks may increase for both workers and residents. These would be similar to the health and safety risks from any construction-type project with earthmoving, crushing, large equipment, transportation of overweight and oversized

\footnotetext{
${ }^{x l}$ If DECON operations are kept in-house, then many employees will be retained for a longer period than they would be under one of the other strategies. This would decrease the likelihood of immediate economic shocks for the local community. Some staff may also be retained in SAFSTOR or ENTOMB as the site is placed in a stable condition. The community may also receive an economic boost from added contractors, or potentially new hires required for the interim storage of waste.
} 
materials, etc. Health and safety issues include working in weather extremes, possible contact with natural hazards including terrain and dangerous plants, animals or insects.

IAEA found planning is of paramount importance to avoid negative impacts on the local community. ${ }^{346}$ The organization supports outlining efforts that will be made to help the community in the decommissioning plan. ${ }^{347}$ This may be drafted in conjunction with community representatives and economists. Topics considered in the plan may include potential job prospects for employees and what resources the community offers. ${ }^{348}$ One such plan for a plant employing DECON could be a provision that current employees or local workers will be used in lieu of specialized contractors. But, because decommissioning requires specialized knowledge, it may be easier to strike a balance between using contractors for decommissioning activities and using current employees to prepare for decommissioning. This could create a gradual decrease of plant workforce rather than a simultaneous widespread laying off of employees. ${ }^{349}$

The closure of Kewaunee Power station, a nuclear facility in Wisconsin, was estimated to cost the three nearest counties over $\$ 630$ million. In response, over 400 community leaders from those counties engaged stakeholders and members of the community to devise an action plan to mitigate these losses. ${ }^{350}$ Their 2013 report estimated that an investment of \$1.5 million to expand their tourism industry and renewable energy infrastructure, among other things, would balance these losses. ${ }^{351}$ An action plan was submitted to the Citrus County Economic Development Council in 2013 following the announced closure of the Crystal River 3 Nuclear Power Plant. Similar community outreach occurred. The focus of the plan was to target industries that could hire former employees of the plant based on the resources Citrus County offers. ${ }^{352}$ Following the closure of three coal plants in West Virginia in 2012, nearly all workers were transferred to other facilities. Because of a gradual downsizing of workforce, community impacts three years after the plants closed were found to be minimal. ${ }^{353}$

Large-scale power plants can be seen as symbols of local communities. As a result, there is sometimes a movement within the community to ensure a portion of the facility is preserved or is repurposed to provide the energy of tomorrow. Re-using the site of a former coal-fired plant can prove to be beneficial to the community for multiple reasons. First, repurposing a plant may bring with it construction and $0 \& \mathrm{M}$ jobs that bolster the local economy or at least offset the loss of jobs. Second, the process of converting the energy source of a plant may require and strengthen a relationship between local government, utilities, and other community groups. ${ }^{354}$

If local and state governments believe decommissioning a facility for reuse can be advantageous to their economies, they may also share the burden of costs between the collaborating party. An option proposed by EPRI is for governments to also provide tax incentives for the facility to be reused. 355 This could include the creation of incentives to promote the reuse of legacy sites as well as programs to train employees. ${ }^{356}$

Nuclear plants can employ hundreds of workers with an average starting salary over $\$ 100,000$. In many nuclear plant communities, there are no other employers to absorb this workforce and pay them a similar salary. Oswego County in New York is bracing for significant economic impacts from the proposed closing of the James A. FitzPatrick Nuclear Power Plant. The nuclear plant provides 
about $50 \%$ of the tax revenues collected by the local school district. The ripple effect of families moving out will put many houses on the market. These empty houses will mean a decrease in revenue for the school district from property taxes. The community will take another economic hit from the lack of the annual refueling at the power plant. Periodic refuelings bring workers from out of state into their hotels and restaurants for over a month each year. ${ }^{357}$

The public has multiple opportunities to have their voices heard in the decommissioning of nuclear sites. By democratizing the decommissioning process across other types of power sector retirements and repurposing decisions, greater community buy-in and support could occur. 358

\subsection{OTHER COMMUNITY IMPACTS}

Potential impacts resulting from power plant decommissioning have many dimensions.

- Acoustics (Noise): Sources of noise during decommissioning would be similar to those during construction that includes rollers, bulldozers, diesel generators, vehicular traffic, etc. The level of the noise would depend on the distance to the nearest residence. For example, if the power plant is located near a residential area, noise levels from some equipment operation could exceed U.S. EPA guidelines but would be intermittent and occur for a limited time. 359

- Air Quality: Decommissioning activities like vehicle tailpipe emissions; diesel emissions from large construction equipment and generators; fugitive dust from land clearing, structure removal, backfilling, dumping, restoration of distributed areas (grading, seeding, planting); and truck and equipment traffic all can result in air, solid waste, and water pollution. ${ }^{360}$

- Ecological Resources: Decommissioning activities may affect wildlife interactions with plant facilities and habitat fragmentation. Also, injury and mortality rates of vegetation and wildlife are much lower than they would be during construction and operation. After site reclamation, ecological resources of the project site may return to its pre-project conditions depending on the end use selected for the project area; however, retrieval of forest or sagebrush habitats could take decades or longer. Invasive species may colonize newly and recently reclaimed areas, and nonnative plants that are not locally adapted could produce contrasts of color, form, texture, and line. ${ }^{361}$

- Land Remediation: Large-scale fossil and nuclear plants have significant land-use reclamation costs. In contrast, the land use impacts resulting from construction and operation of renewable facilities, while they may be expansive, they may be reversed. ${ }^{362}$

- Soils and Geologic Resources: Removal of access and on-site roads, buildings and other structures, and heavy vehicle traffic may impact soil and geologic resources during decommissioning phase. Surface disturbance, heavy equipment traffic, and changes to surface runoff patterns can cause soil erosion resulting in nutrient loss and reduced water quality in nearby surface water bodies; however, after decommissioning is complete, 
disturbed areas would be contoured and revegetated to minimize the potential for soil erosion. Impacts to geologic resources would not be expected. 363

- Visual Resources: During decommissioning, visual impacts would be similar to those from construction; impacts could occur from road development, removal of buried structures and equipment, intermittent or phased activity persisting over extended period of time, and the presence of idle or dismantled equipment, if allowed to remain on site. Restoring a decommissioned site to pre-project conditions may take much longer as it involves recontouring, grading, scarifying, seeding and planting, and may be stabilizing disturbed surfaces; newly disturbed soils would create visual contrasts that would persist several seasons before revegetation would begin to disguise past activity. ${ }^{364}$

- Water Quality: This could be affected by activities that cause soil erosion, weathering of newly exposed soils resulting in leaching and oxidation that could release chemicals into the water, presence of dissolved salts from untreated groundwater used to control dust, and pesticide applications. After decommissioning is complete, disturbed areas would be contoured and revegetated to minimize the potential for soil erosion and impacts related to water quality. 365 


\section{SUMMARY}

The solid waste streams from electricity generation depend not only on the fuels and technologies used to operate power plants, but also on the age and design of the plants and the infrastructure that must be decommissioned when the plants retire. Thus, our analysis distinguishes between solid waste from operations and solid waste from decommissioning.

Coal and nuclear power have significant solid wastes associated with their operation, which require particular attention because of their volume and toxicity. The only significant solid wastes associated with the generation of electricity from oil- and gas-fired plants are emission control wastes. However, these wastes are relatively small in magnitude because emission controls on gasand oil-fired plants are relatively uncommon. Hydropower, wind, and solar power produce little, if any, solid waste during their operation.

In the long-run, all major generation sources face retirement, decommissioning, conversion, repowering, repurposing, or other transitions that involve the management of significant waste streams. All power plants have a finite life beyond which it is no longer economically feasible to operate them. Currently, coal plant retirements dominate as the principal decommissioning activity in the U.S. power sector, followed by the retirement of natural gas, petroleum, and nuclear power plants. These decommissioning activities are therefore major contributors to the production of solid waste in the electricity sector, with associated risks and opportunities.

The nation is experiencing a rapid increase in the number of power plant retirements. Most of the fossil plants that are now being retired did not have decommissioning plans in place either prior to plant construction or during most of their operating lives. The early preparation of decommissioning plans for nuclear plants is more common. The OECD recommends that all nuclear plants develop such plans to minimize costs, simplify the retirement process, and be better prepared in the event of an unexpected sudden shutdown. It would be advantageous for operators of all electricity generating units to develop such retirement plans. Some states require decommissioning plans and financial security for wind and solar facilities, , xli but there is no model approach in place in the United States for preparing such plans for wind, solar, or fossil generation plants.

An influx of solid waste is being created by the growing number of power plant retirements.

New opportunities for recycling materials and for reconditioning and reusing parts may be needed, so that the value embodied by these retired facilities can be maximized and put to best use. Such efforts would presumably benefit the communities that once hosted these same plants. Re-use of materials at the power plant site has significant advantage, if value-added uses can be identified, because the cost of hauling waste to disposal sites can be significant.

Power electronics are used in all types of power plants, and they have multiple toxic solid waste issues that need to be addressed. Electronic equipment in power system applications can utilize polychlorinated biphenyls, lead, brominated flame retardants, and cadmium. At retirement, they

xli See Tables 5.3 and 5.5. 
could have significant negative human health and ecosystem consequences. In particular, with the combination of toxic substances used in printed circuit boards (e.g., lead, brominated fire retardants, and cadmium), the disposal of circuit boards in landfills needs to be controlled. While efforts are underway to manage e-waste, xlii currently, these devices with toxic substances that are essential to power plant operations are not regulated and are disposed as untreated e-wastes in landfills.

The two largest forms of solid waste from coal-fired generation are coal ash (from the combustion of coal), and "scrubber" slurry (from environmental controls at fossil plants). Both of these solid wastes can impact local ecosystems when unplanned releases occur. It costs approximately \$80$\$ 120$ million to phase out ash ponds at a typical U.S. coal plant. Full plant decommissioning to brownfield status is costlier, and conversion for re-use requires additional investments.

Compared to coal and nuclear, gas- and oil-fired electricity generation produces much less solid waste, and fewer major solid waste issues occur during decommissioning, where the largest form of solid waste is chemical waste. These chemical wastes include the scale, sludge and scrapings in the part of the generator, tanks and pipelines. Thus, the focus of decommissioning oil- and gas-fired generation is to safely dispose of chemical contaminated equipment and parts. The disposal methods include removal and in-place decommissioning. Depending on the situation of different equipment and parts, the detailed procedures can be different.

There is little public information about the cost of different decommissioning options. In particular, few reports or articles cover the detailed cost of decommissioning petroleum- and gas-fired plants and renewable generation. There is also limited information about the decommissioning of solar and wind facilities because their life expectancy is roughly 20-30 years and most of them have not yet reached their end-of-life. It is important to know more about decommissioning processes because many oil, diesel, solar and wind facilities will soon reach their end-of-life.

Examples of industrial and mixed-use repurposing of solid waste from coal, gas, and petroleum power plants are emerging. However, there is no federal program of information sharing or best practices for recycling options for solid waste and decommissioned equipment and materials to assist in the repurposing of retired fossil-fueled plant sites.

Nuclear waste requires careful handling. There is currently no centralized waste facility for nuclear waste in the United States for permanent disposal. As a result, waste is stored at reactor sites in 35 states awaiting construction of a permanent waste handling facility. Other countries recycle spent fuel rods, but this process is currently not used in the U.S. due to economic and security concerns.

xlii https://www.epa.gov/international-cooperation/cleaning-electronic-waste-e-waste 
Decommissioning costs of commercial nuclear reactors have ranged widely from $\$ 100$ million to $\$ 700$ million, and sometimes exceeding \$1 billion. Advancements in technology will likely make clean-up and decommissioning cheaper in the future.

Decisions to remove a hydropower dam involve various entities and depend on the regulatory oversight of the dam. State fish and wildlife offices are often involved in the decision making. FERC can ask a hydropower plant to be removed for environmental and safety reasons. The impacts of dam removal can be significant.

In the case of solar power, there is no state or federal requirement that its products be recycled. It is possible that for some solar facilities, the recycling value of the decommissioned facility will exceed the removal costs, providing a net gain. The development of secondary markets for such facilities could be a valuable focus for a future public-private partnership.

The impacts of power plant decommissioning on local communities are clearly significant, but detailed analysis has yet to be completed. The environmental justice issues associated with legacy coal plants warrants examination. The nation needs to ensure that the environmental justice issues that disproportionately exposed low-income and minority populations to air and water pollution during the operation of power plants do not subsequently produce a legacy of solid waste after facilities are shut down, that hamper future economic growth opportunities.

A track record of decommissioning costs and best practices is only now being assembled, and these principally apply to coal, oil, and nuclear plants. The value of salvage, for instance, is unclear, and opportunities to repurpose power plant sites are only now being assessed. Opportunities to share lessons learned could help to reduce negative solid waste consequences and optimize positive opportunities.

If local and state governments believe decommissioning a facility for reuse can be advantageous to their economies, they may also share the burden of costs, as was done with the Google server farm being established at the Widows Creek Fossil Pant in Alabama. Another option for governments is to provide tax incentives to encourage facilities to be re-used. There are currently no widespread information-sharing programs focused on the reuse of legacy fossil plant sites. 
${ }^{1}$ Energy Information Administration, Preliminary Monthly Electric Generator Inventory, Feburary 26, 2016. http://www.eia.gov/electricity/data/eia860m/. Accessed in March 13, 2016.

${ }^{2}$ Energy Information Administration. Frequently Asked Questions. "What is U.S. electricity generation by energy source?" https://www.eia.gov/tools/faqs/faq.cfm?id=427\&t=3. Accessed June 17, 2016.

${ }^{3}$ Energy Information Administration. Today in Energy. "Electricity from natural gas surpasses coal for first time, but just for one month." July 31, 2015. http://www.eia.gov/todayinenergy/detail.cfm?id=22312.

Accessed June 17, 2016.

${ }^{4}$ Energy Information Administration. Today in Energy. "Natural gas expected to surpass coal in mix of fuel used for U.S. power generation in 2016." March 16, 2016.

https://www.eia.gov/todayinenergy/detail.cfm?id=25392. Accessed June 17, 2016.

${ }^{5}$ Energy Information Administration. Today in Energy. "Natural gas expected to surpass coal in mix of fuel used for U.S. power generation in 2016." March 16, 2016.

https://www.eia.gov/todayinenergy/detail.cfm?id=25392. Accessed June 17, 2016.

${ }^{6}$ Marcy, C., J. Logan, J. McCall, F. Flores-Espino, A. Bloom, J. Aabakken, W. Cole, T. Jenkins, and G. Porro.

“Electricity Generation Baseline Report," National Renewable Energy Lab (2016).

${ }^{7}$ Emanuele Massetti, Marilyn Brown, Melissa Lapsa, Isha Sharma, James Bradbury, Colin Cunliff, Yufei Li. Environmental Quality and the U.S. Power Sector: Air Quality, Water Quality, Land Use and Environmental Justice, Oak Ridge National Laboratory, ORNL/SPR-2016/772 (2016).

${ }^{8}$ Energy Information Administration. Frequently Asked Questions. "What is U.S. electricity generation by energy source?" https://www.eia.gov/tools/faqs/faq.cfm?id=427\&t=3. Accessed June 17, 2016.

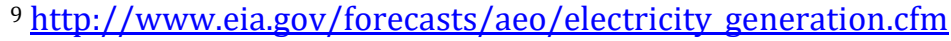

10 Tidball, Rick et al. "Cost and Performance Assumptions for Modeling Electricity Generation Technologies." National Renewable Energy Laboratory. 2010. http://www.nrel.gov/docs/fy11osti/48595.pdf. Accessed January 7, 2016.

${ }^{11}$ Energy Information Administration, Preliminary Monthly Electric Generator Inventory, Feburary 26, 2016. http://www.eia.gov/electricity/data/eia860m/. Accessed in March 13, 2016.

12 The Energy Information Agency publishes statistics on summer power plant capacity because electric utility companies typically have either summer or dual (summer and winter) coincident system peaks.

${ }^{13}$ SNL Energy. "Financial Focus Special Report: Capital Expenditure Update," Edison, NJ: SNL Energy, 2015.

${ }^{14}$ Energy Information Administration, Preliminary Monthly Electric Generator Inventory, Feburary 26, 2016. http://www.eia.gov/electricity/data/eia860m/. Accessed in March 13, 2016.

${ }_{15}$ Ritter, Stephen K. "A New Life for Coal Ash." Chemical \& Engineering News, February 2016, 10-14.

${ }_{16}$ Duke Energy. "How Do Coal-Fired Plants Work?" Generating Electricity with Coal. 2015.

https://www.duke-energy.com/about-energy/generating-electricity/coal-fired-how.asp. Accessed January 27, 2016.

17 U.S. Geological Survey. “Georgia Power's Plant Scherer." A Coal-Fired Thermoelectric Power Plant. 2014. http://water.usgs.gov/edu/wupt-coalplant-diagram.html. Accessed January 27, 2016.

${ }^{18}$ International Energy Agency. "Technology Roadmap: High-Efficiency, Low Emissions Coal-Fired Power Generation." Publications. October 2012: 5.

19 Williams, Jacob. "America's Best Coal Plants." Power Engineering. July 17, 2014. http://www.powereng.com/articles/print/volume-118/issue-7/features/america-s-best-coal-plants.html. Accessed June 14, 2016.

20 International Energy Agency. “Technology Roadmap: High-Efficiency, Low Emissions Coal-Fired Power Generation." Publications. October 2012: 5.

https://www.iea.org/publications/freepublications/publication/TechnologyRoadmapHighEfficiencyLowEmi ssionsCoalFiredPowerGeneration WEB Updated March2013.pdf. Accessed March 20, 2016.

${ }^{21}$ American Electric Power. "Ultra-supercritical Generation." January 2011.

https://www.swepco.com/global/utilities/lib/docs/info/projects/TurkPlant/supercriticalfactsheet.pdf. Accessed April 292016.

22 Department of Energy. "Fluidized Bed Technology-Overview.” Advanced Combustion Technologies. 2016. http://energy.gov/fe/science-innovation/clean-coal-research/advanced-combustion-technologies/fluidizedbed-technology. Accessed April 292016. 
${ }^{23}$ National Energy Technology Laboratory. "Syngas Composition.” Gasification Introduction. 2016. http://www.netl.doe.gov/research/coal/energy-systems/gasification/gasifipedia/syngas-composition. Accessed June 2, 2016.

${ }^{24}$ National Energy Technology Laboratory. "Fixed (Moving) Bed Gasifiers." Commercial Gasifiers. 2016. http://www.netl.doe.gov/research/coal/energy-systems/gasification/gasifipedia/fmb. Accessed June 2, 2016.

${ }^{25}$ National Energy Technology Laboratory. "Fixed (Moving) Bed Gasifiers." Commercial Gasifiers. 2016. http://www.netl.doe.gov/research/coal/energy-systems/gasification/gasifipedia/fmb. Accessed June 2, 2016.

${ }^{26}$ National Energy Technology Laboratory. "Fixed (Moving) Bed Gasifiers.” Commercial Gasifiers. 2016. http://www.netl.doe.gov/research/coal/energy-systems/gasification/gasifipedia/fmb. Accessed June 2, 2016.

${ }^{27}$ National Energy Technology Laboratory. "Fixed (Moving) Bed Gasifiers." Commercial Gasifiers. 2016. http://www.netl.doe.gov/research/coal/energy-systems/gasification/gasifipedia/fmb. Accessed June 2, 2016.

${ }^{28}$ National Energy Technology Laboratory. "Fixed (Moving) Bed Gasifiers.” Commercial Gasifiers. 2016. http://www.netl.doe.gov/research/coal/energy-systems/gasification/gasifipedia/fmb. Accessed June 2, 2016.

${ }^{29}$ National Energy Technology Laboratory. "Fixed (Moving) Bed Gasifiers.” Commercial Gasifiers. 2016. http://www.netl.doe.gov/research/coal/energy-systems/gasification/gasifipedia/fmb. Accessed June 2, 2016.

${ }^{30}$ National Energy Technology Laboratory. "Gasifipedia." Power. 2016. http://www.netl.doe.gov/research/coal/energy-systems/gasification/gasifipedia/igcc-process. Accessed June 2, 2016.

31 Tidball, Rick et al. "Cost and Performance Assumptions for Modeling Electricity Generation Technologies." National Renewable Energy Laboratory. 2010. http://www.nrel.gov/docs/fy11osti/48595.pdf. Accessed January 7, 2016.

32 National Energy Technology Laboratory. "Entrained Flow Gasifiers." Gasifipedia. http://www.netl.doe.gov/research/coal/energy-systems/gasification/gasifipedia/ge. Accessed June 2, 2016.

${ }^{33}$ Department of Energy. "Pioneering Gasification Plants." Office of Fossil Energy. nd. http://energy.gov/fe/science-innovation/clean-coal-research/gasification/pioneering-gasification-plants. Accessed March 20, 2016.

${ }^{34}$ Department of Energy. "Pioneering Gasification Plants." Office of Fossil Energy. nd. http://energy.gov/fe/science-innovation/clean-coal-research/gasification/pioneering-gasification-plants. Accessed March 20, 2016.

35 Duke Energy. "Edwardsport Integrated Gasification Combined Cycle (IGCC) Station." Our Company. http://www.duke-energy.com/about-us/edwardsport-overview.asp. Accessed June 2, 2016.

36 Bine Information Service. "Power Plants with Coal Gasification." Publications. September 2006. http://www.bine.info/fileadmin/content/Publikationen/Englische Infos/projekt 0906 engl internetx.pdf. Accessed March 20, 2016.

${ }^{37}$ National Energy Technology Laboratory. "Gasification Plant Database." Gasification. http://www.netl.doe.gov/research/coal/energy-systems/gasification/gasification-plant-databases. Accessed June 2, 2016.

${ }_{38}$ Marcy, C., J. Logan, J. McCall, F. Flores-Espino, A. Bloom, J. Aabakken, W. Cole, T. Jenkins, and G. Porro, "Electricity Generation Baseline Report," National Renewable Energy Lab (2016).

39 Brown, Marilyn A. and Benjamin K. Sovacool. Climate Change and Global Energy Security: Technology and Policy Options. Cambridge: MIT Press. 2010.

${ }^{40}$ National Energy Technology Laboratory. “CO 2 Compression." Carbon Capture. http://www.netl.doe.gov/research/coal/carbon-capture/co2-compression. Accessed April 292016.

${ }^{41}$ Brown, Marilyn A. and Benjamin K. Sovacool. Climate Change and Global Energy Security: Technology and Policy Options. Cambridge: MIT Press. 2010.

${ }^{42}$ Carbon Capture \& Storage Association. "What is CCS." 2015. http://www.ccsassociation.org/what-is-ccs/. Accessed January 27, 2016.

${ }^{43}$ Environmental Protection Agency. "Carbon Dioxide Capture and Sequestration." Climate Change. 23 February 2016. https://www3.epa.gov/climatechange/ccs/. Accessed 24 April 2016. 
${ }_{44}$ Clean Air Task Force. “Conversion and $\mathrm{CO}_{2}$ Capture.” $\mathrm{CO}_{2}$ Technology Solutions. 2015. http://www.catf.us/fossil/technology/conversion and capture/. Accessed January 27, 2016.

45 Environmental Protection Agency. "Steam Electric Power Generating Point Source Category: Final Detailed Study Report." Page 2-3. October 2009.

${ }^{46}$ Environmental Protection Agency. "Steam Electric Power Generating Point Source Category: Final Detailed Study Report." Page 4-17. October 2009.

${ }^{47}$ American Coal Ash Association. "CCP Faqs." About Coal Ash. 2015a. https://www.acaa-usa.org/About-CoalAsh/CCP-FAQs. Accessed Feburuary 2 2016.- 2.2.1

${ }^{48}$ Perkins+Will. "Fly Ash in Concrete." 2011.

http://transparency.perkinswill.com/Content/Whitepapers/FlyAsh WhitePaper.pdf. Accessed January 11, 2016.

${ }^{49}$ Ritter, Stephen K. "A New Life for Coal Ash." Chemical \& Engineering News, February 2016, 10-14.

${ }^{50}$ Ritter, Stephen K. "A New Life for Coal Ash." Chemical \& Engineering News, February 2016, 10-14.

51 Environmental Protection Agency. "Frequent Questions about the Coal Ash Disposal Rule." July 92015. https://www.epa.gov/coalash/frequent-questions-about-coal-ash-disposal-rule\#20. Accessed March 20, 2016.

52 American Coal Ash Association. "All CCPs Production and Use with Percent". 2015. https://www.acaausa.org/Portals/9/Files/PDFs/2014CCPProdandUseCharts.pdf. Accessed January 212016.

53 Federal Highway Administration. "Coal Bottom Ash/Boiler Slag." User Guidelines for Waste and Byproduct Materials in Pavement Construction." March 82016.

https://www.fhwa.dot.gov/publications/research/infrastructure/structures/97148/cbabs1.cfm. Accessed May 92016.

54 Federal Highway Administration. "Coal Bottom Ash/Boiler Slag." User Guidelines for Waste and Byproduct Materials in Pavement Construction." March 82016.

https://www.fhwa.dot.gov/publications/research/infrastructure/structures/97148/cbabs1.cfm. Accessed May 92016.

${ }^{55}$ Energy Information Administration. "Subbituminous and Bituminous Coal Dominate U.S. Coal Production." Today in Energy. August 16 2011. http://www.eia.gov/todayinenergy/detail.cfm?id=2670. Accessed April 20 2016.

${ }^{56}$ National Energy Technology Laboratory. "Comparison of the Environmental Performance of IGCC with PC and Fluidized Bed Power Plants." Solid Waste/Byproducts of Gasification. 2016.

http://www.netl.doe.gov/research/Coal/energy-systems/gasification/gasifipedia/comparison-byproducts. Accessed January 30, 2016.

${ }^{57}$ National Energy Technology Laboratory. "Comparison of the Environmental Performance of IGCC with PC and Fluidized Bed Power Plants." Solid Waste/Byproducts of Gasification. 2016.

http://www.netl.doe.gov/research/Coal/energy-systems/gasification/gasifipedia/comparison-byproducts. Accessed January 30, 2016.

58 Energy Information Administration. "Analysis of Heat Rate Improvement Potential at Coal-Fired Power Plants." Analysis and Projections. May 192015.

http://www.eia.gov/analysis/studies/powerplants/heatrate/. Accessed June 2, 2016.

${ }^{59}$ Electric Power Research Institute. "Coal Ash: Characteristics, Management, and Environmental Issues." Palo Alto. 2009. doi:1019022.

${ }^{60}$ Electric Power Research Institute. "Comparison of Coal Combustion Products to Other Common Materials." Palo Alto, CA. 2010

${ }^{61}$ Electric Power Research Institute. "Coal Ash: Characteristics, Management, and Environmental Issues." Palo Alto. 2009. doi:1019022.

62 Electric Power Research Institute. "Coal Ash: Characteristics, Management, and Environmental Issues." Palo Alto. 2009. doi:1019022.

${ }^{63}$ Miser, Tim. "The Coal Ash Rule: How the EPA's Recent Ruling Will Affect the Way Plants Manage CCRs." Power. 2015. http://www.power-eng.com/articles/print/volume-119/issue-2/features/abma-specialsection/the-coal-ash-rule-how-the-epa-s-recent-ruling-will-affect-the-way-plants-manage-ccrs.html. Accessed March 17, 2016.

64 Environmental Protection Agency. "Fact Sheet: Final Rule on Coal Combustion Residuals Generated by Electric Utilities." Files. December 2014. https://www.epa.gov/sites/production/files/2014-

12/documents/factsheet ccrfinal 2.pdf Accessed March 19, 2016. 
65 Miser, Tim. "The Coal Ash Rule: How the EPA's Recent Ruling Will Affect the Way Plants Manage CCRs." Power. 2015. http://www.power-eng.com/articles/print/volume-119/issue-2/features/abma-specialsection/the-coal-ash-rule-how-the-epa-s-recent-ruling-will-affect-the-way-plants-manage-ccrs.html. Accessed March 17, 2016.

${ }^{66}$ Environmental Protection Agency. "Frequent Questions about the Coal Ash Disposal Rule." July 92015. https://www.epa.gov/coalash/frequent-questions-about-coal-ash-disposal-rule\#20 Accessed March 7, 2016. ${ }^{67}$ Johnson, Hank. "Coal Ash Landfill Safety Act." Page 1. United States House of Representatives. March 15, 2016. http://hankjohnson.house.gov/press-release/rep-johnson-introduces-bill-protect-constituents-toxiccoal-ash. Accessed June 19, 2016.

${ }^{68}$ Johnson, Hank. "Coal Ash Landfill Safety Act." Page 2 United States House of Representatives. March 15, 2016. http://hankjohnson.house.gov/press-release/rep-johnson-introduces-bill-protect-constituents-toxiccoal-ash. Accessed June 19, 2016.

${ }^{69}$ Johnson, Hank. "Coal Ash Landfill Safety Act." Page 3. United States House of Representatives. March 15, 2016. http://hankjohnson.house.gov/press-release/rep-johnson-introduces-bill-protect-constituents-toxiccoal-ash. Accessed June 19, 2016.

${ }^{70}$ Johnson, Hank. "Coal Ash Landfill Safety Act." Page 3. United States House of Representatives. March 15, 2016. http://hankjohnson.house.gov/press-release/rep-johnson-introduces-bill-protect-constituents-toxiccoal-ash. Accessed June 19, 2016.

${ }^{71}$ Johnson, Hank. "Coal Ash Landfill Safety Act." Page 5. United States House of Representatives. March 15, 2016. http://hankjohnson.house.gov/press-release/rep-johnson-introduces-bill-protect-constituents-toxiccoal-ash. Accessed June 19, 2016.

72 Environmental Protection Agency. "Frequent Questions about the Coal Ash Disposal Rule." July 92015. https://www.epa.gov/coalash/frequent-questions-about-coal-ash-disposal-rule\#20. Accessed March 20, 2016.

${ }^{73}$ Tennessee Valley Authority. “Paradise Coal Combustion Residuals.” Environment. 2016.

https://www.tva.gov/Environment/Environmental-Stewardship/Coal-Combustion-Residuals/Paradise. Accessed June 2, 2016.

${ }^{74}$ Perkins+Will. "Fly Ash in Concrete." 2011.

http://transparency.perkinswill.com/Content/Whitepapers/FlyAsh WhitePaper.pdf. Accessed January 11, 2016.

75 Perkins+Will. "Fly Ash in Concrete." 2011. http://transparency.perkinswill.com/Content/Whitepapers/FlyAsh WhitePaper.pdf. Accessed January 11, 2016.

${ }^{76}$ Chattanooga Free Times Press. "TVA to Ship Spilled Coal Ash." 2009.

http://www.timesfreepress.com/news/news/story/2009/jun/06/tva-ship-spilled-coal-ash/222350/. Accessed January 212016.

77 Chattanooga Free Times Press. "TVA to Ship Spilled Coal Ash." 2009.

http://www.timesfreepress.com/news/news/story/2009/jun/06/tva-ship-spilled-coal-ash/222350/. Accessed January 212016.

${ }^{78}$ Gang, Duane W. "5 Years After Coal-Ash Spill, Little Has Changed." USA Today. December 23, 2013. http://www.usatoday.com/story/news/nation/2013/12/22/coal-ash-spill/4143995/. Accessed June 9 2016.

79 Zucchino, David. "Tons of Coal Ash Spill into North Carolina River." Los Angeles Times. February 4, 2014. http://articles.latimes.com/2014/feb/04/nation/la-na-coal-ash-20140205. Accessed November 3, 2015.

79 Electric Power Research Institute. "Coal Ash: Characteristics, Management, and Environmental Issues." Palo Alto. 2009. doi:1019022.

${ }^{80}$ Harkness, Jennifer, Barry Sulkin and Avner Vengos. "Evidence for Coal Ash Ponds Leaking in Southeastern United States," Page A. Environmental Science and Technology. June 10, 2016. DOI: 10.1021/acs.est.6b01727. Accessed June 19, 2016.

${ }^{81}$ Harkness, Jennifer, Barry Sulkin and Avner Vengos. "Evidence for Coal Ash Ponds Leaking in Southeastern United States," Page A. Environmental Science and Technology. June 10, 2016. DOI: 10.1021/acs.est.6b01727. Accessed June 19, 2016.

$82 \mathrm{http}: / /$ www.myajc.com/news/news/state-regional-govt-politics/ga-power-to-speed-closure-of-coal-ashponds/nrfsf/ 
83 Zucchino, David. “Tons of Coal Ash Spill into North Carolina River.” Los Angeles Times. February 4, 2014. http://articles.latimes.com/2014/feb/04/nation/la-na-coal-ash-20140205 . Accessed November 3, 2015. 84 Electric Power Research Institute. "Coal Ash: Characteristics, Management, and Environmental Issues." Palo Alto. 2009. doi:1019022.

85 Perkins+Will. "Fly Ash in Concrete." 2011.

http://transparency.perkinswill.com/Content/Whitepapers/FlyAsh WhitePaper.pdf. Accessed January 11, 2016.

86 Perkins+Will. "Fly Ash in Concrete." 2011.

http://transparency.perkinswill.com/Content/Whitepapers/FlyAsh WhitePaper.pdf. Accessed January 11, 2016.

${ }^{87}$ Environmental Protection Agency. "Hazardous and Solid Waste Management System; Disposal of Coal Combustion Residuals from Electric Utilities." Federal Register 80, no 74 (April 17 2015).

https://www.gpo.gov/fdsys/pkg/FR-2015-04-17/pdf/2015-00257.pdf. Accessed 24 April 2016.

88 Electric Power Research Institute. "Coal Ash: Characteristics, Management, and Environmental Issues." Palo Alto. 2009. doi:1019022.

89 Electric Power Research Institute. "Coal Ash: Characteristics, Management, and Environmental Issues." Palo Alto. 2009. doi:1019022.

${ }^{90}$ J.P. McBride et al. "Radiological Impact of Airborne Effluents of Coal-Fired and Nuclear Power Plants." Oak Ridge National Laboratory. August 1977.

http://www.iaea.org/inis/collection/NCLCollectionStore/ Public/09/362/9362611.pdf. Accessed April 21, 2016.

${ }^{91}$ Hvistendahl, Mara. "Coal Ash is More Radioactive Than Nuclear Waste." Scientific American. December 13, 2007. http://www.scientificamerican.com/article/coal-ash-is-more-radioactive-than-nuclear-waste/. Accessed March 20, 2016.

92 Electric Power Research Institute. "Coal Ash: Characteristics, Management, and Environmental Issues." Palo Alto. 2009. doi:1019022.

93 Electric Power Research Institute. "Coal Ash: Characteristics, Management, and Environmental Issues." Palo Alto. 2009. doi:1019022.

${ }^{94}$ American Coal Ash Association. "CCP Faqs." About Coal Ash. 2015. https://www.acaa-usa.org/About-CoalAsh/CCP-FAQs. Accessed Feburuary 22016.

${ }_{95}$ Energy Information Administration. “Coal." Short-Term Energy Outlook. June 7, 2016. https://www.eia.gov/forecasts/steo/report/coal.cfm. Accessed June 14, 2016.

${ }^{96}$ Electric Power Research Institute. "Coal Ash: Characteristics, Management, and Environmental Issues." Palo Alto. 2009. doi:1019022.

${ }^{97}$ Federal Highway Administration. "Coal Fly Ash". User Guidelines for Waste and Byproduct Materials in Pavement Construction. March 82016.

https://www.fhwa.dot.gov/publications/research/infrastructure/structures/97148/cfa53.cfm. Accessed May 92016.

${ }_{98}$ Perkins+Will. "Fly Ash in Concrete." 2011.

http://transparency.perkinswill.com/Content/Whitepapers/FlyAsh WhitePaper.pdf. Accessed January 11,

${ }_{99}$ Ritter, Stephen K. "A New Life for Coal Ash." Chemical \& Engineering News, February 2016: 10-14.

100 Slag Cement Association. "Slag Cement and the Environment." 2013.

http://www.qcrm4.com/downloads/5 SlagCementEnvironmental Benefits.pdf. Accessed March 5, 2016.

101 Federal Highway Administration. "Coal Bottom Ash/Boiler Slag." User Guidelines for Waste and Byproduct Materials in Pavement Construction." March 82016.

https://www.fhwa.dot.gov/publications/research/infrastructure/structures/97148/cbabs1.cfm. Accessed May 92016.

102 Electric Power Research Institute. "Coal Ash: Characteristics, Management, and Environmental Issues." Palo Alto. 2009. doi:1019022.

${ }^{103}$ Environmental Protection Agency. "Hazardous and Solid Waste Management System; Disposal of Coal

Combustion Residuals from Electric Utilities." Page 49. Federal Register 80, no 74 (April 17 2015). https://www.gpo.gov/fdsys/pkg/FR-2015-04-17/pdf/2015-00257.pdf. Accessed 24 April 2016.

${ }^{104}$ Environmental Protection Agency. "Hazardous and Solid Waste Management System; Disposal of Coal Combustion Residuals from Electric Utilities." Page 49. Federal Register 80, no 74 (April 17 2015).

https://www.gpo.gov/fdsys/pkg/FR-2015-04-17/pdf/2015-00257.pdf. Accessed 24 April 2016. 
105 Environmental Protection Agency. "Hazardous and Solid Waste Management System; Disposal of Coal Combustion Residuals from Electric Utilities." Page 49. Federal Register 80, no 74 (April 17 2015). https://www.gpo.gov/fdsys/pkg/FR-2015-04-17/pdf/2015-00257.pdf. Accessed 24 April 2016. 106 Environmental Protection Agency. "Hazardous and Solid Waste Management System; Disposal of Coal Combustion Residuals from Electric Utilities.” Page 49. Federal Register 80, no 74 (April 17 2015). https://www.gpo.gov/fdsys/pkg/FR-2015-04-17/pdf/2015-00257.pdf. Accessed 24 April 2016. 107 Environmental Protection Agency. "Hazardous and Solid Waste Management System; Disposal of Coal Combustion Residuals from Electric Utilities." Page 51. Federal Register 80, no 74 (April 17 2015). https://www.gpo.gov/fdsys/pkg/FR-2015-04-17/pdf/2015-00257.pdf. Accessed 24 April 2016. 108 Strock, N.G. and R.C. Stehouwer. "Soil Additives and Soil Amendments." Chapter 10 In W.B. White (ed). Coal ash beneficial use in mine reclamation and mine drainage remediation in Pennsylvania. \# 5600-UK-DEP3132, 2004.

${ }^{109}$ American Coal Ash Association. "All CCPs Production and Use with Percent". 2015. https://www.acaausa.org/Portals/9/Files/PDFs/2014CCPProdandUseCharts.pdf. Accessed January 212016.

${ }^{110}$ Anthracite Region Independent Power Producers Association (ARIPPA). "Coal Refuse." Files. 2014. http://environmental.pasenategop.com/files/2015/06/Brisini-Testimony3.pdf. Accessed March 16, 2016. ${ }_{111}$ Anthracite Region Independent Power Producers Association (ARIPPA). "Coal Refuse." Files. 2014. http://environmental.pasenategop.com/files/2015/06/Brisini-Testimony3.pdf. Accessed March 16, 2016. 112 Emerson Process Management. "Lime / Limestone Wet Scrubbing System for Flue Gas Desulfurization." Power Industry. 2014. http://www2.emersonprocess.com/siteadmincenter/PM Rosemount Analytical Documents/Liq ADS 4900-02.pdf. Accessed January 4, 2016. - 2.2.2

${ }^{113}$ National Energy Technology Laboratory. "Comparison of the Environmental Performance of IGCC with PC and Fluidized Bed Power Plants." Solid Waste/Byproducts of Gasification. 2016. http://www.netl.doe.gov/research/Coal/energy-systems/gasification/gasifipedia/comparison-byproducts. Accessed January 30, 2016.

${ }^{114}$ Srivastava, R. K. and W. Jozewicz. "Flue Gas Desulfurization: The State of the Art." Journal of the Air \& Waste Management Association 51, no. 12 (2001): 1676-688.

115 Srivastava, R. K. and W. Jozewicz. "Flue Gas Desulfurization: The State of the Art." Journal of the Air \& Waste Management Association 51, no. 12 (2001): 1676-688.

116 Emerson Process Management. "Lime / Limestone Wet Scrubbing System for Flue Gas Desulfurization." Power Industry. 2014. http://www2.emersonprocess.com/siteadmincenter/PM Rosemount Analytical Documents/Liq_ADS 4900-02.pdf. Accessed January 4, 2016.

117 Federal Highway Administration. "FGD Scrubber Material." User Guidelines for Waste and Byproduct Materials in Pavement Construction." March 82016.

https://www.fhwa.dot.gov/publications/research/infrastructure/pavements/97148/025.cfm. Accessed May 9, 2016.

118 Melda, Aaron Paul. TVA, March 13, 2016, "Cumberland Fossil Plant Gypsum Marketing Summary," Personal communication.

119 Melda, Aaron Paul. TVA, March 13, 2016, "Cumberland Fossil Plant Gypsum Marketing Summary," Personal communication.

${ }^{120}$ Ritter, Stephen K. "A New Life for Coal Ash." Chemical \& Engineering News, February 2016: 10-14.

${ }^{121}$ National Energy Technology Laboratory. "Comparison of the Environmental Performance of IGCC with PC and Fluidized Bed Power Plants." Solid Waste/Byproducts of Gasification. 2016.

http://www.netl.doe.gov/research/Coal/energy-systems/gasification/gasifipedia/comparison-byproducts. Accessed January 30, 2016.

122 Environmental Protection Agency. "Final Effluent Limitations Guidelines and Standards for the Steam Electric Power Generating Industry." Office of Water. September 2015. 1.

https://www.epa.gov/sites/production/files/2015-10/documents/steam-electric-final-rule-factsheet 1001-2015.pdf. Accessed May 24, 2016.

${ }^{123}$ Environmental Protection Agency. "Steam Electric Power Generating Point Source Category: Final Detailed Study Report." Files. p xii. October 2009. https://www.epa.gov/sites/production/files/201506/documents/steam-electric detailed study report 2009.pdf. Accessed May 24, 2016.

${ }^{124}$ Environmental Protection Agency. "Final Effluent Limitations Guidelines and Standards for the Steam Electric Power Generating Industry." Office of Water. September 2015. 2. 
https://www.epa.gov/sites/production/files/2015-10/documents/steam-electric-final-rule-factsheet 1001-2015.pdf. Accessed May 24, 2016.

125 Environmental Protection Agency. "Steam Electric Power Generating Point Source Category: Final Detailed Study Report." Files. p xii. October 2009. https://www.epa.gov/sites/production/files/2015-

06/documents/steam-electric detailed study report 2009.pdf. Accessed May 24, 2016.

${ }^{126}$ Environmental Protection Agency. "Steam Electric Power Generating Point Source Category: Final Detailed Study Report." Files. p xii. October 2009. https://www.epa.gov/sites/production/files/2015-

06/documents/steam-electric detailed study report 2009.pdf. Accessed May 24, 2016.

127 Environmental Protection Agency. "Final Effluent Limitations Guidelines and Standards for the Steam Electric Power Generating Industry." Office of Water. September 2015. 1.

https://www.epa.gov/sites/production/files/2015-10/documents/steam-electric-final-rule-factsheet 1001-2015.pdf. Accessed May 24, 2016.

${ }^{128}$ Environmental Protection Agency. "Final Effluent Limitations Guidelines and Standards for the Steam Electric Power Generating Industry." Office of Water. September 2015. 1.

https://www.epa.gov/sites/production/files/2015-10/documents/steam-electric-final-rule-factsheet 1001-2015.pdf. Accessed May 24, 2016.

${ }^{129}$ Environmental Protection Agency. "Regulatory Impact Analysis for the Final Mercury and Air Toxics Standards." United States Nuclear Regulatory Commission Official Hearing Exhibit. March 30 2012. 76. http://www.nrc.gov/docs/ML1233/ML12339A607.pdf. Accessed May 242016.

130 Environmental Protection Agency. "Regulatory Impact Analysis for the Final Mercury and Air Toxics Standards." United States Nuclear Regulatory Commission Official Hearing Exhibit. March 30 2012. 76. http://www.nrc.gov/docs/ML1233/ML12339A607.pdf. Accessed May 242016.

${ }^{131}$ Environmental Protection Agency. "Regulatory Impact Analysis for the Final Mercury and Air Toxics Standards." United States Nuclear Regulatory Commission Official Hearing Exhibit. March 30 2012. 76. http://www.nrc.gov/docs/ML1233/ML12339A607.pdf. Accessed May 242016.

132 Martin, Richard and Mackinnon Lawrence. "Coal Plant Decommissioning." Navigant Research. 2013.

${ }^{133}$ Ball, Jeffrey. "5.3 Billion Reasons Why Companies That Built Coal Plants Now Want to Tear Them Down." New Republic, (2014): 3-7.

${ }^{134}$ Martin, Richard and Mackinnon Lawrence. "Coal Plant Decommissioning." Navigant Research. 2013.

135 Martin, Richard and Mackinnon Lawrence. "Coal Plant Decommissioning." Navigant Research. 2013.

${ }^{136}$ SNL Energy. "Financial Focus Special Report: Capital Expenditure Update," Edison, NJ: SNL Energy, 2015.

137 SNL Energy. "Financial Focus Special Report: Capital Expenditure Update," Edison, NJ: SNL Energy, 2015.

138 Martin, Richard and Mackinnon Lawrence. "Coal Plant Decommissioning." Navigant Research. 2013.

139 Martin, Richard and Mackinnon Lawrence. "Coal Plant Decommissioning." Navigant Research. 2013.

${ }^{140}$ Ball, Jeffrey. "5.3 Billion Reasons Why Companies That Built Coal Plants Now Want to Tear Them Down."

New Republic, (2014): 3-7.

${ }^{141}$ Martin, Richard and Mackinnon Lawrence. "Coal Plant Decommissioning." Navigant Research. 2013.

142 Electric Power Research Institute. "Decommissioning Handbook for Coal-Fired Power Plants." Vol. 3. Palo Alto. 2006. doi:1011220.

143 Martin, Richard and Mackinnon Lawrence. "Coal Plant Decommissioning." Navigant Research. 2013.

${ }^{144}$ Martin, Richard and Mackinnon Lawrence. "Coal Plant Decommissioning." Navigant Research. 2013.

145 Johnson, Mark and Kent Nisson. "Successful Coal Ash Management. Power Engineering. 17 July 2014. http://www.power-eng.com/articles/print/volume-118/issue-7/features/successful-coal-ash-pondmanagement.html. Accessed April 272016.

${ }^{146}$ EOP Group, Inc. "Cost Estimates for the Mandatory Closure of Surface Impoundments Used for the Management of Coal Combustion Byproducts at Coal-Fired Electric Utilities." 2009.

https://www.whitehouse.gov/sites/default/files/omb/assets/oira_2050/2050_102809-2.pdf. Accessed January 222016.

147 EOP Group, Inc. "Cost Estimates for the Mandatory Closure of Surface Impoundments Used for the Management of Coal Combustion Byproducts at Coal-Fired Electric Utilities." 2009.

https://www.whitehouse.gov/sites/default/files/omb/assets/oira 2050/2050 102809-2.pdf. Accessed January 222016.

148 Tennessee Valley Authority. "New Uses for Coal Byproducts." Energy. https://www.tva.gov/Energy/OurPower-System/Fossil-Fuel-Generation/New-Uses-for-Coal-Byproducts-Feature. Accessed June 4, 2016 
149 Electric Power Research Institute. "Decommissioning Handbook for Coal-Fired Power Plants." Vol. 3. Palo Alto. 2006. doi:1011220.

150 Electric Power Research Institute. "Decommissioning Handbook for Coal-Fired Power Plants." Vol. 3. Palo Alto. 2006. doi:1011220.

151 Electric Power Research Institute. "Decommissioning Handbook for Coal-Fired Power Plants." Vol. 3. Palo Alto. 2006. doi:1011220.

152 Electric Power Research Institute. “Decommissioning Handbook for Coal-Fired Power Plants.” Vol. 3. Palo Alto. 2006. doi:1011220.

${ }^{153}$ American Clean Skies Foundation. "Repurposing Legacy Power Plants: Lessons for the Future." August 1, 2011. http://www.potomacrivergreen.org/wpcontent/uploads/2016/01/ACSF layout coverANDtext.pdf. Accessed December 16, 2015.

${ }^{154}$ Electric Power Research Institute. “Decommissioning Handbook for Coal-Fired Power Plants." Vol. 3. Palo Alto. 2006. doi:1011220.

155 Electric Power Research Institute. "Decommissioning Handbook for Coal-Fired Power Plants." Vol. 3. Palo Alto. 2006. doi:1011220.

${ }^{156}$ Energy Information Administration. “Coal." Short-Term Energy Outlook. June 7, 2016.

https://www.eia.gov/forecasts/steo/report/coal.cfm. Accessed June 14, 2016.

157 American Coal Ash Association. "CCP Faqs." About Coal Ash. 2015. https://www.acaa-usa.org/About-CoalAsh/CCP-FAQs. Accessed Feburuary 22016.

${ }^{158}$ EOP Group, Inc. "Cost Estimates for the Mandatory Closure of Surface Impoundments Used for the Management of Coal Combustion Byproducts at Coal-Fired Electric Utilities." 2009.

https://www.whitehouse.gov/sites/default/files/omb/assets/oira_2050/2050 102809-2.pdf. Accessed January 222016.

${ }^{159}$ Ball, Jeffrey. "5.3 Billion Reasons Why Companies That Built Coal Plants Now Want to Tear Them Down." New Republic, (2014): 3-7.

160 Martin, Richard and Mackinnon Lawrence. "Coal Plant Decommissioning." Navigant Research. 2013.

${ }^{161}$ Energy Information Administration. Frequently Asked Questions. "What is U.S. electricity generation by energy source?" https://www.eia.gov/tools/faqs/faq.cfm?id=427\&t=3. Accessed June 17, 2016.

162 Emanuele Massetti, Marilyn Brown, Melissa Lapsa, Isha Sharma, James Bradbury, Colin Cunliff, Yufei Li. Environmental Quality and the U.S. Power Sector: Air Quality, Water Quality, Land Use and Environmental Justice, Oak Ridge National Laboratory, ORNL/SPR-2016/772 (2016), Figure 2.1.

163 Emanuele Massetti, Marilyn Brown, Melissa Lapsa, Isha Sharma, James Bradbury, Colin Cunliff, Yufei Li. Environmental Quality and the U.S. Power Sector: Air Quality, Water Quality, Land Use and Environmental Justice, Oak Ridge National Laboratory, ORNL/SPR-2016/772 (2016), Table 2.12.

164 Department of Energy. "How Gas Turbine Power Plants Work." Office of Fossil Energy. 2015.

http://energy.gov/fe/how-gas-turbine-power-plants-work. Accessed January 282016.

165 Department of Energy. "How Gas Turbine Power Plants Work." Office of Fossil Energy. 2015.

http://energy.gov/fe/how-gas-turbine-power-plants-work. Accessed January 282016.

166 Lind, A. and E. Sällberg. Optimization of the Start-up Procedure of a Combined Cycle Power Plant. ISSN 0280-5316. (2012): Chapter 2, Page 24, Figure 2.8.

167 Department of Energy. "Current and Future Technologies for Natural Gas Combined Cycle (NGCC) Power Plants" Office of Fossil Energy. January 2013. Chapter 2, Page 17.

http://netl.doe.gov/File\%20Library/Research/Energy\%20Analysis/Publications/NGCC SOA ADV_Rev1 201 30610.pdf. Accessed April 21, 2016.

168 Berkenpas, M.P., K. Kietzke, H. Mantripragada, S.T. McCoy, and E.S. Rubin. "Integrated Environmental Control Model -Technical Documentation. May 1999: Chapter 3, Page 13.

https://www.cmu.edu/epp/iecm/IECM_Publications/1999ra\%20Berkenpas\%20et\%20al,\%20IECM\%20Tec h.pdf Accessed March 23, 2016.

169 Berkenpas, M.P., K. Kietzke, H. Mantripragada, S.T. McCoy, and E.S. Rubin. Integrated Environmental Control Model -Technical Documentation. May 1999: Chapter 6, Page 98.

170 Energy Information Administration. Electric Power Annual, Table "2014 Form EIA-860 Data - Schedule 6E, 'FGP Data." February 2016. http://www.eia.gov/electricity/annual/. Accessed March 14, 2016.

${ }^{171}$ Energy Information Administration, Electric Power Annual, Table "2014 Form EIA-860 Data - Schedule 6E, 'FGD Data." February 2016,. http://www.eia.gov/electricity/annual/. Accessed March 14, 2016. 
172 Energy Information Administration, Electric Power Annual, Table "2014 Form EIA-860 Data - Schedule 6E, 'FGP Data." February 2016. http://www.eia.gov/electricity/annual/. Accessed March 14, 2016.

173 National Research Council, Committee on Health, Environmental, Other External Costs, Benefits of Energy Production, and Consumption. Hidden costs of energy: unpriced consequences of energy production and use.

(National Academies Press, 2010: 97, 121). DOI: 10.17226/12794.

174 National Research Council, Committee on Health, Environmental, Other External Costs, Benefits of Energy Production, and Consumption. Hidden costs of energy: unpriced consequences of energy production and use.

(National Academies Press, 2010: 97, 121). DOI: 10.17226/12794.

175 Pepco Energy Services."Decommissioning the Benning Road Power Plant." 2014.

http://www.benningservicecenter.com/benning-power-plant-closure/factsheet.aspx. Accessed January 4, 2016.

176 Pepco Energy Services. "Benning Road Power Plant: Decommissioning and Demolition Project." Octorber, 2014. Page 5.

http://static1.squarespace.com/static/527154c0e4b09a993f80e460/t/545d17f6e4b042c56b56e272/1415 387126360/McNulty PPR Demo MD-DCUtilities Presentation Final.pdf. Accessed January 7, 2016.

177 Pepco Energy Services. "Benning Road Power Plant: Decommissioning and Demolition Project." Octorber, 2014. Page 6.

http://static1.squarespace.com/static/527154c0e4b09a993f80e460/t/545d17f6e4b042c56b56e272/1415 387126360/McNulty PPR Demo MD-DCUtilities Presentation_Final.pdf. Accessed January 7, 2016.

178 Pepco Energy Services. "Benning Road Power Plant: Decommissioning and Demolition Project." Octorber, 2014. Page 5.

http://static1.squarespace.com/static/527154c0e4b09a993f80e460/t/545d17f6e4b042c56b56e272/1415 387126360/McNulty PPR Demo MD-DCUtilities Presentation Final.pdf. Accessed January 7, 2016.

${ }^{179}$ Lynn, Kathleen. "Costly Cleanup: Buried oil tanks can break home sale deals." October 2011.

http://www.bergen.com/201magazine/201estates/featured/costly-cleanup-buried-oil-tanks-can-breakhome-sale-deals-1.831974. Accessed April 22, 2016.

180 Michigan Department of Environmental Quality. "Decommissioning an Abandoned Crude Oil Pipeline with Numerous Regulatory Stakeholders Utilizing Multiple Funding Mechanisms." December 2004. Page 49-50. http://info.ngwa.org/GWOL/pdf/041278687.pdf. Accessed March 19, 2016,

${ }^{181}$ Federal Register, Code of Federal Regulations Title 49 Subtitle B Chapter I Subchapter D Part 195 \&192.

May 6, 2016. http://www.ecfr.gov/cgi-bin/text-idx?tpl=/ecfrbrowse/Title49/49cfr195 main 02.tpl.

Accessed May 7, 2016.

182 Hong Kong Environment Protection Department. "Decommissioning of Two Open Cycle Gas Turbine Units and Associated Facilities at Tsing Yi Power Station." September 2003: Chapter 5.3 \& Chapter 5.4

http://www.epd.gov.hk/eia/register/profile/latest/dir090.pdf Accessed March 19, 2016.

$183 \mathrm{http}: / /$ pubs.usgs.gov/fs/fs-0142-99/fs-0142-99.pdf http://pubs.usgs.gov/fs/fs-0142-99/fs-0142-99.pdf

${ }_{184}$ World Nuclear Association. "Naturally-Occurring Radioactive Materials (NORM)". July 2015.

http://www.world-nuclear.org/information-library/safety-and-security/radiation-and-health/naturallyoccurring-radioactive-materials-norm.aspx. Accessed April 16, 2016.

185 United States Geological Survey. "Naturally Occurring Radioactive Materials (NORM) in Produced Water and Oil-Field Equipment- An Issue for the Energy Industry." Chapter 5, Page 3. September 1999.

https://pubs.usgs.gov/fs/fs-0142-99/fs-0142-99.pdf. Accessed April 15, 2016.

${ }_{186}$ Railroad Commission of Texas, “NORM (Naturally Occurring Radioactive Material)”, August 27, 2015.

http://www.rrc.state.tx.us/oil-gas/applications-and-permits/environmental-permit-types-

information/norm/ Accessed April 15, 2016.

187 National Energy Technology Laboratory. "Life Cycle Analysis: Natural Gas Combined Cycle (NGCC) Power Plant." 2010: Chapter 2, Page 52. http://www.netl.doe.gov/energy-

analyses/temp/FY13 LifeCycleAnalysisNaturalGasCombinedCycle\%28NGCC\%29PowerPlantFinal 060113.p df. Accessed March 16, 2016.

188 Odeh, N.A. and T.T. Cockerill. "Life cycle GHG assessment of fossil fuel power plants with carbon capture and storage." Energy Policy, no. 36(2008): Chapter 2.2, Page 372.

http://citeseerx.ist.psu.edu/viewdoc/download?doi=10.1.1.461.4252\&rep=rep1\&type=pdf. Accessed April 15, 2016.

${ }^{189}$ Energy Information Administration, Electric Power Annual, Table "2014 Form EIA-860 Data - Schedule 6E, 'FGP Data." February 2016. http://www.eia.gov/electricity/annual/. Accessed March 14, 2016. 
${ }^{190}$ Nuclear Regulatory Commission. "Power Reactors.” Nuclear Reactors. November 62015. http://www.nrc.gov/reactors/power.html. Accessed May 7, 2016.

191 World Nuclear Association, "Nuclear Power Reactors." Nuclear Fuel Cycle. 2016. http://www.worldnuclear.org/information-library/nuclear-fuel-cycle/nuclear-power-reactors/nuclear-power-reactors.aspx. Accessed May 7, 2016.

192 Nuclear Energy Institute. "FAQ About Nuclear Energy." Knowledge Center. 2015. http://www.nei.org/Knowledge-Center/FAQ-About-Nuclear-Energy. Accessed December 3, 2015. 193 World Nuclear Association. "Comparison of Lifecycle Greenhouse Gas Emissions of Various Electricity Generation Sources." WNA Report. July 2011. 6-7. http://www.worldnuclear.org/uploadedFiles/org/WNA/Publications/Working Group Reports/comparison of lifecycle.pdf. Accessed June 6, 2016.

${ }^{194}$ Nuclear Regulatory Commission. "Backgrounder on Radioactive Waste." Fact Sheets. April 32015. http://www.nrc.gov/reading-rm/doc-collections/fact-sheets/radwaste.html. Accessed March 19, 2016. 195 Nuclear Energy Institute “On-Site Storeage of Nuclear Waste." Knowledge Center. 2016. http://www.nei.org/Knowledge-Center/Nuclear-Statistics/On-Site-Storage-of-Nuclear-Waste. Accessed March 7, 2016.

${ }^{196}$ U.S. Government Accountability Office. "Spent Nuclear Fuel: Legislative, Technical, and Societal Challenges to Its Transportation." Testimony. October 12015 . http://www.gao.gov/assets/680/672889.pdf. Accessed May 5, 2016.

197 Rosner, Robert and Rebecca Lordan. "Why America should Move Toward Dry Cask Consolidated Interim Storage of used Nuclear Fuel." Bulletin of the Atomic Scientists 70, no. 6 (2014): 48-62.

198 Nuclear Energy Institute "On-Site Storeage of Nuclear Waste." Knowledge Center. 2016. http://www.nei.org/Knowledge-Center/Nuclear-Statistics/On-Site-Storage-of-Nuclear-Waste. Accessed March 7, 2016.

${ }^{199}$ Rosner, Robert and Rebecca Lordan. "Why America should Move Toward Dry Cask Consolidated Interim Storage of used Nuclear Fuel." Bulletin of the Atomic Scientists 70, no. 6 (2014): 48-62.

${ }^{200}$ Rosner, Robert and Rebecca Lordan. "Why America should Move Toward Dry Cask Consolidated Interim Storage of used Nuclear Fuel." Bulletin of the Atomic Scientists 70, no. 6 (2014): 48-62.

${ }^{201}$ Nuclear Energy Institute. "FAQ About Nuclear Energy." Knowledge Center. 2015. http://www.nei.org/Knowledge-Center/FAQ-About-Nuclear-Energy. Accessed December 3, 2015. ${ }^{202}$ Nuclear Energy Institute. "FAQ About Nuclear Energy." Knowledge Center. 2015. http://www.nei.org/Knowledge-Center/FAQ-About-Nuclear-Energy. Accessed December 3, 2015. ${ }^{203}$ Nuclear Regulatory Commission. "Backgrounder on Radioactive Waste." Fact Sheets. April 32015. http://www.nrc.gov/reading-rm/doc-collections/fact-sheets/radwaste.html. Accessed March 19, 2016. 204 Nuclear Regulatory Commission. "Locations of Low-Level Waste Disposal Facilities." Radioactive Waste. April 8 2016. http://www.nrc.gov/waste/llw-disposal/licensing/locations.html. Accessed May 5, 2016. 205 Polonsky, Alex S. and Ray P. Kuyler. 2014. "U.S. Commercial Nuclear Plants: A National Resource for 80 Years or More." Nuclear Plant Journal 32, no. 3 (2014): 32-35.

${ }^{206}$ Nuclear Energy Institute. "License Renewal of Nuclear Power Plants." Fact Sheets. April 2016. http://www.nei.org/Master-Document-Folder/Backgrounders/Fact-Sheets/License-Renewal-of-NuclearPower-Plants. Accessed May 5, 2016.

207 Nuclear Regulatory Commission. “Guiding Our Reviews of Subsequent License Renewal.” Blog. https://public-blog.nrc-gateway.gov/2015/12/29/guiding-our-reviews-of-subsequent-license-renewal/. Accessed May 6, 2016.

${ }^{208}$ Nuclear Energy Institute. “License Renewal of Nuclear Power Plants." Fact Sheets. April 2016. http://www.nei.org/Master-Document-Folder/Backgrounders/Fact-Sheets/License-Renewal-of-NuclearPower-Plants. Accessed May 5, 2016.

${ }^{209}$ SNL Energy. "Financial Focus Special Report: Capital Expenditure Update," Edison, NJ: SNL Energy, 2015. 210 Entergy. "Entergy Intends to Refuel Pilgrim in 2017; Cease Operations on May 31, 2019." Operational Update. April 14, 2016. http://www.pilgrimpower.com/operational-update/. Accessed June 16, 2016. ${ }^{211}$ Entergy. "Entergy to Close James A. Fitzpatrick Nuclear Power Plant in Central New York." Operational Update. February 23, 2016. http://www.fitzpatrickpower.com/operational-update.html. Accessed June 16, 2016.

212 Exelon. "Exelon Announces Early Retirement of Clinton and Quad Cities Nuclear Plants." Newsroom. June 2, 2016. http://www.exeloncorp.com/newsroom/clinton-and-quad-cities-retirement. Accessed June 16, 2016. 
213 State of New Jersey Department Environmental Protection. "Comprehensive Plan of Action Item \#1: Close Oyster Creek Nuclear Power Plant." Barnegat Bay. 2014. http://www.nj.gov/dep/barnegatbay/planoystercreek.htm. Accessed June 16, 2016.

${ }^{214}$ Nuclear Regulatory Commission. "Combined License Applications for New Reactors." Nuclear Reactors. February 18 2016. http://www.nrc.gov/reactors/new-reactors/col.html. Accessed May 6, 2016.

${ }^{215}$ Nuclear Regulatory Commission. "Questions and Answers Decommissioning Planning Final Rule." April, 10 2015. http://pbadupws.nrc.gov/docs/ML1127/ML11271A197.pdf. Accessed March 19, 2016.

216 Larson, Aaron. "Riding Off Into The Sunset: Nuclear Decontamination And Decommissioning Update." Power 159, no. 7 (2015): 56-60.

217 Nuclear Regulatory Commission. "Questions and Answers Decommissioning Planning Final Rule." United States Nuclear Regulatory Commission, April, 102015.

http://pbadupws.nrc.gov/docs/ML1127/ML11271A197.pdf. Accessed March 19, 2016.

${ }^{218}$ Nuclear Regulatory Commission. "Backgrounder on Decommissioning Nuclear Power Plants." Nuclear Regulatory Commission. "Backgrounder on Decommissioning Nuclear Power Plants." Fact Sheets. May 1, 2015. 2015. http://www.nrc.gov/reading-rm/doc-collections/fact-sheets/decommissioning.html. Accessed November 8, 2015.

${ }^{219}$ Nuclear Regulatory Commission. "Backgrounder on Decommissioning Nuclear Power Plants." Nuclear Regulatory Commission. "Backgrounder on Decommissioning Nuclear Power Plants." Fact Sheets. May 1, 2015. 2015. http://www.nrc.gov/reading-rm/doc-collections/fact-sheets/decommissioning.html. Accessed November 8, 2015.

${ }^{220}$ International Atomic Energy Agency. "Transition from Operation to Decommissioning of Nuclear Installations," STI/DOC/010/420. 2004. http://wwwpub.iaea.org/MTCD/publications/PDF/TRS420 web.pdf. Accessed March 18, 2016.

${ }^{221}$ International Atomic Energy Agency. "Decommissioning Strategies: Status, Trends and Issues." n.d. https://www.iaea.org/About/Policy/GC/GC54/GC54InfDocuments/English/gc54inf-3-att4 en.pdf. Accessed March 17, 2016.

222 World Nuclear Association. "Decommissioning Nuclear Facilities." no. April: 1-12. 2015. http://www.world-nuclear.org/information-library/nuclear-fuel-cycle/nuclear-wastes/decommissioningnuclear-facilities.aspx. Accessed March 19, 2016.

${ }^{223}$ Larson, Aaron. "Riding Off Into The Sunset: Nuclear Decontamination And Decommissioning Update." Power 159, no. 7 (2015): 56-60.

${ }^{224}$ Synapse Energy Economics, Inc. "The Real Cost of Cleaning up Nuclear Waste: A Full Cost of Accounting of Cleanup Options for the West Valley Nuclear Waste Site." Page 133. Decommissioning.

http://www.nirs.org/radwaste/decommissioning/wvfcareport1108.pdf. November 2008. Accessed June 16, 2016.

225 World Nuclear Association. "Decommissioning Nuclear Facilities.” no. April: 1-12. 2015.

http://www.world-nuclear.org/information-library/nuclear-fuel-cycle/nuclear-wastes/decommissioningnuclear-facilities.aspx. Accessed March 19, 2016.

${ }^{226}$ World Nuclear Association. "Decommissioning Nuclear Facilities." no. April: 1-12. 2015.

http://www.world-nuclear.org/information-library/nuclear-fuel-cycle/nuclear-wastes/decommissioningnuclear-facilities.aspx. Accessed March 19, 2016.

${ }^{227}$ World Nuclear Association. "Decommissioning Nuclear Facilities." no. April: 1-12. 2015.

http://www.world-nuclear.org/information-library/nuclear-fuel-cycle/nuclear-wastes/decommissioningnuclear-facilities.aspx. Accessed March 19, 2016.

${ }^{228}$ Audette, Bob. "NRC Discusses Nuclear Plant Closing Costs." The Brattleboro Reformer. 2010.

${ }^{229}$ Lochbaum, David. "Life After Nuclear: Decommissioning Power Reactors." Bulletin Of The Atomic Scientists

70, no. 4 (2014): 26-36.

230 Organization for Economic Co-operation and Development/Organisation de Cooperation et de Developpement Economiques. "Decommissioning Nuclear Power Plants: Policies, Strategies and Costs." ProQuest. Paris: OECD. 2003.

231 Organization for Economic Co-operation and Development/Organisation de Cooperation et de Developpement Economiques. "Decommissioning Nuclear Power Plants: Policies, Strategies and Costs." 232 Organization for Economic Co-operation and Development/Organisation de Cooperation et de Developpement Economiques. "Decommissioning Nuclear Power Plants: Policies, Strategies and Costs." 
233 International Atomic Energy Agency. "Transition from Operation to Decommissioning of Nuclear Installations," STI/DOC/010/420. 2004. Accessed March 18, 2016.

${ }^{234}$ Larson, Aaron. "Riding Off Into The Sunset: Nuclear Decontamination And Decommissioning Update." Power 159, no. 7 (2015): 56-60.

235 Electric Power Research Institute. "In Use: Nuclear Decommissioning Technology." Road Maps. 2015. http://mydocs.epri.com/docs/Portfolio/P2016/Roadmaps/NUC CLR 10-Decommissioning-Technology.pdf. Accessed March 19, 2016.

236 World Nuclear Association. “Decommissioning Nuclear Facilities.” no. April: 1-12. 2015. http://www.world-nuclear.org/information-library/nuclear-fuel-cycle/nuclear-wastes/decommissioningnuclear-facilities.aspx. Accessed March 19, 2016.

237 World Nuclear Association. "Decommissioning Nuclear Facilities." no. April: 1-12. 2015. http://www.world-nuclear.org/information-library/nuclear-fuel-cycle/nuclear-wastes/decommissioningnuclear-facilities.aspx. Accessed March 19, 2016.

238 Nuclear Regulatory Commission. "Backgrounder on Decommissioning Nuclear Power Plants." Fact Sheets. May 1, 2015. http://www.nrc.gov/reading-rm/doc-collections/fact-sheets/decommissioning.html. Accessed November 8, 2015.

${ }^{239}$ Nuclear Regulatory Commission. "Backgrounder on Decommissioning Nuclear Power Plants." Fact Sheets. May 1, 2015. 2015. http://www.nrc.gov/reading-rm/doc-collections/fact-sheets/decommissioning.html. Accessed November 8, 2015.

240 World Nuclear Association. “Decommissioning Nuclear Facilities." no. April: 1-12. 2015. http://www.world-nuclear.org/information-library/nuclear-fuel-cycle/nuclear-wastes/decommissioningnuclear-facilities.aspx. Accessed March 19, 2016.

241 World Nuclear Association. "Decommissioning Nuclear Facilities." no. April: 1-12. 2015. http://www.world-nuclear.org/information-library/nuclear-fuel-cycle/nuclear-wastes/decommissioningnuclear-facilities.aspx. Accessed March 19, 2016.

${ }^{242}$ Nuclear Regulatory Commission. "Backgrounder on Radioactive Waste." Fact Sheets. April 32015. http://www.nrc.gov/reading-rm/doc-collections/fact-sheets/radwaste.html. Accessed March 19, 2016. 243 World Nuclear Association. "Decommissioning Nuclear Facilities," no. April: 1-12. 2015, http://www.world-nuclear.org/information-library/nuclear-fuel-cycle/nuclear-wastes/decommissioningnuclear-facilities.aspx. Accessed March 19, 2016.

${ }^{244}$ World Nuclear Association. "Decommissioning Nuclear Facilities." no. April: 1-12. 2015. http://www.world-nuclear.org/information-library/nuclear-fuel-cycle/nuclear-wastes/decommissioningnuclear-facilities.aspx. Accessed March 19, 2016.

245 World Nuclear Association. "Decommissioning Nuclear Facilities." no. April: 1-12. 2015. http://www.world-nuclear.org/information-library/nuclear-fuel-cycle/nuclear-wastes/decommissioningnuclear-facilities.aspx. Accessed March 19, 2016.

${ }^{246}$ Nuclear Regulatory Commission. "Backgrounder on Radioactive Waste." Fact Sheets. April 32015. http://www.nrc.gov/reading-rm/doc-collections/fact-sheets/radwaste.html. Accessed March 19, 2016. 247 Larson, Aaron. "Riding Off Into The Sunset: Nuclear Decontamination And Decommissioning Update." Power 159, no. 7 (2015): 56-60.

248 Lochbaum, David. "Life After Nuclear: Decommissioning Power Reactors. "Bulletin Of The Atomic Scientists 70, no. 4 (2014): 26-36.

249 World Nuclear Association. “Decommissioning Nuclear Facilities." no. April: 1-12. 2015. http://www.world-nuclear.org/information-library/nuclear-fuel-cycle/nuclear-wastes/decommissioningnuclear-facilities.aspx. Accessed March 19, 2016.

${ }^{250}$ Lochbaum, David. "Life After Nuclear: Decommissioning Power Reactors." Bulletin Of The Atomic Scientists 70, no. 4 (2014): 26-36.

${ }^{251}$ World Nuclear Association. “Decommissioning Nuclear Facilities.” no. April: 1-12. 2015. http://www.world-nuclear.org/information-library/nuclear-fuel-cycle/nuclear-wastes/decommissioningnuclear-facilities.aspx. Accessed March 19, 2016.

${ }^{252}$ Nuclear Regulatory Commission. "Backgrounder on Radioactive Waste." Fact Sheets. April 32015. http://www.nrc.gov/reading-rm/doc-collections/fact-sheets/radwaste.html. Accessed March 19, 2016. 253 World Nuclear Association. "Decommissioning Nuclear Facilities." no. April: 1-12. 2015. http://www.world-nuclear.org/information-library/nuclear-fuel-cycle/nuclear-wastes/decommissioningnuclear-facilities.aspx. Accessed March 19, 2016. 
${ }^{254}$ Nuclear Energy Institute. "FAQ About Nuclear Energy." Knowledge Center. 2015.

http://www.nei.org/Knowledge-Center/FAQ-About-Nuclear-Energy. Accessed December 3, 2015.

255 International Atomic Energy Agency. "Decommissioning Strategies: Status, Trends and Issues." n.d. https://www.iaea.org/About/Policy/GC/GC54/GC54InfDocuments/English/gc54inf-3-att4_en.pdf. Accessed March 17, 2016.

${ }^{256}$ World Nuclear Association. "Decommissioning Nuclear Facilities." no. April: 1-12. 2015.

http://www.world-nuclear.org/information-library/nuclear-fuel-cycle/nuclear-wastes/decommissioningnuclear-facilities.aspx. Accessed March 19, 2016.

${ }^{257}$ Larson, Aaron. "Riding Off Into The Sunset: Nuclear Decontamination And Decommissioning Update."

Power 159, no. 7 (2015): 56-60.

258 Energy Information Administration. "Electric Power Monthly," Online:

http://www.eia.gov/electricity/monthly/epm table grapher.cfm?t=epmt 1 1, Accessed March 6, 2016.

${ }^{259}$ Energy Iinformation Administration. "Electric Power Monthly." http://www.eia.gov/electricity/monthly/. Accessed March 6, 2016.

${ }^{260}$ U.S. Society on Dams (USSD). “Committee on Dam Decommissioning,” Online:

http://www.ussdams.org/c decom.html, Accessed: 05 May 2016.

${ }^{261}$ Department of Energy. "2014 Hydropower Market Report" April 2015, Page 5 Online:

http://energy.gov/sites/prod/files/2015/05/f22/2014\%20Hydropower\%20Market\%20Report 20150512 rev6.pdf.

262 American Rivers. http://www.americanrivers.org/initiatives/dams/faqs/. Accessed May 5, 2016.

${ }^{263}$ American Rivers. http://www.americanrivers.org/initiatives/dams/faqs/. Accessed May 5, 2016.

${ }^{264}$ Association of State Dam Safety, "The Cost of Rehabilitating Our Nation’s Dams," January 2009.

http://www.damsafety.org/media/Documents/DownloadableDocuments/RehabilitationCosts2009.pdf, Page 3.

265 Department of Energy., "2014 Hydropower Market Report" April 2015, Page 24 Online:

http://energy.gov/sites/prod/files/2015/05/f22/2014\%20Hydropower\%20Market\%20Report_20150512_ rev6.pdf

266 Page 9

http://energy.gov/sites/prod/files/2015/05/f22/2014\%20Hydropower\%20Market\%20Report_20150512_ rev6.pdf

${ }^{267}$ Federal Energy Management Agency. "Summary of Existing Guidelines for Hydrologic Safety of Dams,"

August 1, 2012.

${ }^{268}$ Federal Energy Management Agency. Dam Safety in the United States, Page 6, Online:

http://www.fema.gov/media-library-data/1402876995238-

1c041ca9a4489ea27152c515ed72e38f/DamSafetyintheUnitedStates.pdf

269 ORNL, 2014 Hydropower Market Report, April 2015 Online

http://www.energy.gov/sites/prod/files/2015/04/f22/2014\%20Hydropower\%20Market\%20Report_2015 0424.pdf.

270 U.S. Society on Dams (USSD). Guidelines for Dam Decommissioning Projects, July 2015.

${ }^{271}$ Randle, T.J. and T.E. Hepler. "USSD Guidelines for Dam Decommissioning Projects, Executive Summary."

2012: 855-870. http://ussdams.com/proceedings/2012Proc/855.pdf. Accessed March 17, 2016.

272 Executive Office of Energy and Environmental Affairs "Dam Removal in Massachusetts: A Basic Guide for

Project Proponents" December 2007. http://www.mass.gov/eea/docs/eea/water/damremoval-guidance.pdf.

${ }^{273}$ S. Pacca, "Impacts from decommissioning of hydroelectric dams: a life cycyle perspective," Climate Change,

2007.

${ }^{274}$ S. Pacca, "Impacts from decommissioning of hydroelectric dams: a life cycle perspective," Climate Change,

2007.

275 USSD, “Committee on Dam Decommissioning," Online: http://www.ussdams.org/c_decom.html

276 Crane, Misti. "River ecosystems show 'incredible' initial recovery after dam removal". phys.org.

http://phys.org/news/2015-12-river-ecosystems-incredible-recovery.html. December 28, 2015. Accessed

March 17, 2016

277 Randle, T., J. Bountry, A. Ritchie, and K. Wille. (2015). Large-scale dam removal on the Elwha River,

Washington, USA: Erosion of reservoir sediment. Geomorphology, 246, 709-728.

${ }^{278}$ Bureau of Land Management (BLM), "Renewable Energy and the BLM: Wind," September 29, 2015, Online: http://www.blm.gov/wo/st/en/prog/energy/wind energy.html. Accessed March 17, 2016. 
279 Energy Information Administration (EIA). Today in Energy. March 23, 2016. Accessed June 14, 2016. Online: http://www.eia.gov/todayinenergy/detail.cfm?id=25492

${ }^{280}$ Energy Efficiency \& Renewable Energy, "2014 Wind Technologies Market Report" August 2015. Online: http://energy.gov/sites/prod/files/2015/08/f25/2014-Wind-Technologies-Market-Report-8.7.pdf, Page iv. 281 EIA, "Short-Term Energy and Summer Fuels Outlook", Online: https://www.eia.gov/forecasts/steo/report/renew co2.cfm, April 2016, Accessed: May 9, 2016 282 Federal Register. "Competitive Processes, Terms, and Conditions for Leasing Public Lands for Solar and Wind Energy." 79, no. 189 (2014): 59022-59083/Proposed Rules. http://www.blm.gov/style/medialib/blm/wo/MINERALS REALTY AND RESOURCE PROTECTION /energ y/solar and wind.Par.4208.File.dat/Solar\%20and\%20Wind\%20Competitive\%20Leasing\%20Proposed\%20 Rule.pdf. Accessed March 19, 2016.

${ }^{283}$ Danielle Changala, Michael Dworkin, Jay Apt, Paulina Jaramillo, Comparative Analysis of Conventional Oil and Gas and Wind Project Decommissioning Regulations on Federal, State, and County Lands, The Electricity Journal, Volume 25, Issue 1, January-February 2012, Pages 29-45

${ }^{284}$ Danielle Changala, Michael Dworkin, Jay Apt, Paulina Jaramillo, Comparative Analysis of Conventional Oil and Gas and Wind Project Decommissioning Regulations on Federal, State, and County Lands, The Electricity Journal, Volume 25, Issue 1, January-February 2012, Pages 29-45. Page 39.

${ }^{285}$ National Renewable Energy Laboratory (NREL). "Wind Power Project Repowering: Financial Feasibility, Decision Drivers, and Supply Chain Effects", December 2013, Online:

http://www.nrel.gov/docs/fy14osti/60535.pdf

${ }^{286}$ Black Oak Wind Farm: Decommissioning Plan, 2011. http://www.blackoakwindny.com/wpcontent/uploads/Appendix E - Preliminary Decommissioning_Plan.pdf/.

287 DOE, "Wind Vision: A New Era for Wind Power in the United States", Online: http://energy.gov/sites/prod/files/2015/03/f20/wv full report.pdf, Page 72

288 NREL. Wind Power Project Repowering: Financial Feasibility, Decision Drivers, and Supply Chain Effects. December 2013.

${ }^{289}$ Shannon L. Ferrell, Eric A. DeVuyst, Decommissioning wind energy projects: An economic and political analysis, Energy Policy, Volume 53, February 2013, Pages 105-113, ISSN 0301-4215

${ }^{290}$ Canadian Solar Aria, “Decommissioning Plan Report," September 2012.

http://ariasolarproject.com/Aria\%20-\%20Nov\%202013/Aria\%20Tab\%204\%20\%20Decommissioning\%20Plan\%20Report.pdf.

${ }^{291}$ Black Oak Wind Farm: Decommissioning Plan, 2011. http://www.blackoakwindny.com/wpcontent/uploads/Appendix E - Preliminary_Decommissioning_Plan.pdf/.

292 USSD, Decommissioning of Dam Projects. Online http://www.ussdams.org/c_decom.html

293 USSD, Guidelines for Dam Decommissioning Projects, July 2015. Online:

http://www.ussdams.org/15Decommissioning.PDF

${ }^{294}$ Black Oak Wind Farm: Decommissioning Plan, 2011. http://www.blackoakwindny.com/wpcontent/uploads/Appendix E - Preliminary_Decommissioning_Plan.pdf/.

295 Black Oak Wind Farm: Decommissioning Plan, 2011. http://www.blackoakwindny.com/wpcontent/uploads/Appendix E - Preliminary Decommissioning_Plan.pdf/.

${ }^{296}$ Mark J. Kaiser, Brian Snyder, Offshore wind decommissioning regulations and workflows in the Outer Continental Shelf United States, Marine Policy, Volume 36, Issue 1, January 2012, Pages 113-121

${ }^{297}$ Wind Energy: The Facts, Article “Decommissioning Wind Turbines” July 2013.

http://www.cleanenergycouncil.org.au/technologies/wind-energy.html.

298 Wind Energy: The Facts, Article “Decommissioning Wind Turbines" July 2013.

http://www.cleanenergycouncil.org.au/technologies/wind-energy.html.

${ }^{299}$ A Scoping Level Study of the Economics of Wind-Project Repowering Decisions in California" (PDF). KEMA, Inc. August 2008. http://www.energy.ca.gov/2008publications/CEC-300-2008-004/CEC-300-2008-004.PDF 300 Solar Energy Industries Association (SEIA). "US Solar Market Sets New Record, Installing 7.3 GW of solar PV in 20155," February 22, 2016. Accessed: June 13, 2016. Online http://www.seia.org/news/us-solarmarket-sets-new-record-installing-73-gw-solar-pv-2015 ${ }^{301}$ Solar Energy Industries Association (SEIA). “US Solar Market Insight,” Updated June 9, 2016. Accessed: June 13, 2016. Online: http://www.seia.org/research-resources/us-solar-market-insight 
302 Alternate Energy, Common Types of Solar Cells, Online:

http://www.altenergy.org/renewables/solar/common-types-of-solar-cells.html

$303 \mathrm{http}$ // www.seia.org/news/us-solar-market-sets-new-record-installing-73-gw-solar-pv-2015

${ }^{304}$ http://www.seia.org/news/us-solar-market-sets-new-record-installing-73-gw-solar-pv-2015

305 Massachusetts Department of Energy Resources. Ground Mounted Solar Photovoltaic Systems. June 2015. Online: http://www.mass.gov/eea/docs/doer/renewables/solar/solar-pv-guide.pdf

${ }^{306}$ https://nccleantech.ncsu.edu/wp-content/uploads/Solar-Decommissioning-Policy-Working-Paper.pdf

307 Union of Concerned Scientists (UCSD). Environmental Impacts of Solar Power. March 5, 2013. Accessed

June 14 2016. Online: http://www.ucsusa.org/clean_energy/our-energy-choices/renewable-

energy/environmental-impacts-solar-power.html\#.V2AVo7srLct

308 Apple One, "Apple One Solar Farm Decommissioning Plan," December 12, 2014.

http://www.catawbacountync.gov/Planning/Projects/Rezonings/RZ2014-06Decommission.pdf.

${ }^{309}$ Apple One, "Apple One Solar Farm Decommissioning Plan," December 12, 2014.

http://www.catawbacountync.gov/Planning/Projects/Rezonings/RZ2014-06Decommission.pdf.

${ }^{310}$ Apple One, “Apple One Solar Farm Decommissioning Plan," December 12, 2014.

http://www.catawbacountync.gov/Planning/Projects/Rezonings/RZ2014-06Decommission.pdf.

${ }^{311}$ Brouwer, K.A. et al. "Methods and Concerns for Disposal of Photovoltaic Solar Panels, Report presented to San Jose State University. 2011.

http://citeseerx.ist.psu.edu/viewdoc/download?doi=10.1.1.456.5648\&rep=rep1\&type=pdf. Accessed March 17, 2016.

312 Brouwer, K.A. et al. "Methods and Concerns for Disposal of Photovoltaic Solar Panels, Report presented to San Jose State University. 2011.

http://citeseerx.ist.psu.edu/viewdoc/download?doi=10.1.1.456.5648\&rep=rep1\&type=pdf. Accessed March 17, 2016.

313 World Nuclear Association. "Decommissioning Nuclear Facilities," April, 2015. http://www.world-

nuclear.org/information-library/nuclear-fuel-cycle/nuclear-wastes/decommissioning-nuclear-facilities.aspx. Accessed March 19, 2016.

314 Waitkus, Dave. "AEP dismantles Tidd Plant facilities." August 6, 2015.

http://aepretirees.com/2015/08/06/aep-dismantles-tidd-plant-facilities/. Accessed March 18, 2016.

315 Waitkus, Dave. "AEP dismantles Tidd Plant facilities." August 6, 2015.

http://aepretirees.com/2015/08/06/aep-dismantles-tidd-plant-facilities/. Accessed March 18, 2016.

316 Pepco Energy Services."Decommissioning the Benning Road Power Plant." October, 2014.

http://www.benningservicecenter.com/benning-power-plant-closure/factsheet.aspx. Accessed January 4, 2016.

317 Pepco Energy Services. "Benning Road Power Plant: Decommissioning and Demolition Project." October 2014: 41,

http://static1.squarespace.com/static/527154c0e4b09a993f80e460/t/545d17f6e4b042c56b56e272/1415 387126360/McNulty PPR Demo MD-DCUtilities Presentation Final.pdf. Accessed January 7, 2016.

${ }^{318}$ Code of Federal Regulations, Chapter 40, Part 61, Subpart M, April 2016. http://www.ecfr.gov/cgi-

bin/text-idx?tpl=/ecfrbrowse/Title40/40cfr61_main_02.tpl. Accessed May 3, 2016

319 Pepco Energy Services."Decommissioning the Benning Road Power Plant." October, 2014.

http://www.benningservicecenter.com/benning-power-plant-closure/factsheet.aspx. Accessed January 4, 2016.

${ }^{320}$ Environmental Protection Agency. Asbestos NESHAP." 2015. https://www.epa.gov/asbestos/asbestos-

neshap. Accessed March 10, 2016.

${ }^{321}$ Environmental Protection Agency. "National List of Asbestos Landfills." Document Display. 1992.

http://nepis.epa.gov/Exe/ZyPDF.cgi/000001EP.PDF?Dockey=000001EP.PDF. Accessed March 17, 2016.

322 Pepco Energy Services. "Benning Road Power Plant: Decommissioning and Demolition Project." October,

2014: 27.

http://static1.squarespace.com/static/527154c0e4b09a993f80e460/t/545d17f6e4b042c56b56e272/1415

387126360/McNulty PPR Demo MD-DCUtilities Presentation Final.pdf. Accessed January 7, 2016.

323 Environmental Protection Agency. "Lead Laws and Regulations". July, 2015.

https://www.epa.gov/lead/lead-laws-and-regulations. Accessed April 7, 2016 
${ }^{324}$ Environmental Protection Agency. "Lead-Based Paint and Demolition." January 22, 2016.

http://www.epa.gov/large-scale-residential-demolition/lead-based-paint-and-demolition Accessed April 22, 2016.

325 Pepco Energy Services. "Benning Road Power Plant: Decommissioning and Demolition Project." October, 2014: 34.

http://static1.squarespace.com/static/527154c0e4b09a993f80e460/t/545d17f6e4b042c56b56e272/1415 387126360/McNulty PPR Demo_MD-DCUtilities Presentation Final.pdf. Accessed January 7, 2016.

326 United Nations Environmental Program. "Elimination of PCB."

http://www.unep.org/chemicalsandwaste/POPs/ChemicalsManagementandReduction/EliminationofPCB/ta bid/1059869/Default.aspx. Accessed May 3, 2016.

327 Department of Energy, “Disposal Requirements for PCB Waste.” December 1994: 2.

http://homer.ornl.gov/sesa/environment/guidance/tsca/pcb-disp.pdf. Access January 7, 2016.

${ }^{328}$ Electric Power Research Institute. "Decommissioning Handbook for Coal-Fired Power Plants." Vol. 3. Palo Alto. doi:1011220. 2006: Chapter 2, Page 8.

${ }^{329}$ Electronic Code Of Federal Regulations. "Code of Federal Regulations Part 761-Polychlorinated Biphenyls (PCBs) manufacturing, processing, distribution in commerce, and use prohibition", Subpart D Commercial Storage Approvals Issued. 2016. http://www.ecfr.gov/cgi-bin/textidx?tpl=/ecfrbrowse/Title40/40cfr761 main 02.tpl. Accessed May 5, 2016.

${ }^{330}$ Department of Energy, Office of Electricity Delivery \& Energy Reliability. "Energy Storage."

http://energy.gov/oe/services/technology-development/energy-storage. Accessed April 7, 2016.

${ }^{331}$ Albir, Francisco Javier Hurtado and Jose Antonio Carrasco Hernandez. "Environmental Aspects of Manufacturing and Disposal of Power Electronics Equipment." EPE Journal 21, no. 3 (2011): 5-13.

332 Birnbaum, L.S. and D.F. Staskal. "Brominated flame retardants: cause for concern? "Environmental Health Perspectives, 112, no. 1 (2004): 9-17.

http://www.ncbi.nlm.nih.gov/pmc/articles/PMC1241790/pdf/ehp0112-000009.pdf. Accessed April 7, 2016.

${ }_{333}$ Albir, Francisco Javier Hurtado and Jose Antonio Carrasco Hernandez. "Environmental Aspects of

Manufacturing and Disposal of Power Electronics Equipment." EPE Journal 21, no. 3 (2011): 5-13.

${ }^{334}$ https://www.epa.gov/international-cooperation/cleaning-electronic-waste-e-waste

335 International Atomic Energy Agency. "Managing the Socioeconomic Impact of Decommissioning Nuclear Facilities." Publications. 1. 2008. http://www-pub.iaea.org/MTCD/publications/PDF/trs464 web.pdf.

Accessed May 82016.

${ }^{336}$ International Atomic Energy Agency. "Managing the Socioeconomic Impact of Decommissioning Nuclear Facilities." Publications. 11. 2008. http://www-pub.iaea.org/MTCD/publications/PDF/trs464 web.pdf. Accessed May 82016.

337 International Atomic Energy Agency. "Managing the Socioeconomic Impact of Decommissioning Nuclear Facilities." Publications. 10. 2008. http://www-pub.iaea.org/MTCD/publications/PDF/trs464 web.pdf.

Accessed May 82016.

338 International Atomic Energy Agency. "Managing the Socioeconomic Impact of Decommissioning Nuclear Facilities." Publications. 12. 2008. http://www-pub.iaea.org/MTCD/publications/PDF/trs464 web.pdf. Accessed May 82016.

339 Gideon, Gavin. "Closing of Power Plants Expected to Have Ripple Effect for Other Businesses in Union Township." Pittsburgh Post-Gazette. 21 July 2013. http://www.postgazette.com/business/businessnews/2013/07/21/Closing-of-power-plants-expected-to-have-ripple-effectfor-other-businesses-in-Union-Township/stories/201307210265. Accessed May 112016.

340 International Atomic Energy Agency. "Managing the Socioeconomic Impact of Decommissioning Nuclear Facilities." Publications. 11. 2008. http://www-pub.iaea.org/MTCD/publications/PDF/trs464 web.pdf.

Accessed May 82016.

${ }^{341}$ International Atomic Energy Agency. "Managing the Socioeconomic Impact of Decommissioning Nuclear Facilities." Publications. 12. 2008. http://www-pub.iaea.org/MTCD/publications/PDF/trs464 web.pdf. Accessed May 82016.

342 International Atomic Energy Agency. "Managing the Socioeconomic Impact of Decommissioning Nuclear Facilities." Publications. 16. 2008. http://www-pub.iaea.org/MTCD/publications/PDF/trs464 web.pdf.

Accessed May 82016.

343 Tribal Energy and Environmental Information. "Oil and Gas Decommissioning/Reclamation Impacts." Oil \& Gas. http://teeic.indianaffairs.gov/er/oilgas/impact/decom/index.htm. Accessed May 72016. 
344 International Atomic Energy Agency. "Managing the Socioeconomic Impact of Decommissioning Nuclear Facilities." Publications. 17. 2008. http://www-pub.iaea.org/MTCD/publications/PDF/trs464 web.pdf.

Accessed May 82016.

345 International Atomic Energy Agency. "Managing the Socioeconomic Impact of Decommissioning Nuclear Facilities." Publications. 22. 2008. http://www-pub.iaea.org/MTCD/publications/PDF/trs464 web.pdf.

Accessed May 82016.

346 International Atomic Energy Agency. "Managing the Socioeconomic Impact of Decommissioning Nuclear Facilities." Publications. 24. 2008. http://www-pub.iaea.org/MTCD/publications/PDF/trs464 web.pdf. Accessed May 82016.

${ }^{347}$ International Atomic Energy Agency. "Managing the Socioeconomic Impact of Decommissioning Nuclear Facilities." Publications. 26. 2008. http://www-pub.iaea.org/MTCD/publications/PDF/trs464 web.pdf.

Accessed May 82016.

348 International Atomic Energy Agency. "Managing the Socioeconomic Impact of Decommissioning Nuclear Facilities." Publications. 27. 2008. http://www-pub.iaea.org/MTCD/publications/PDF/trs464 web.pdf.

Accessed May 82016.

${ }^{349}$ International Atomic Energy Agency. "Managing the Socioeconomic Impact of Decommissioning Nuclear

Facilities." Publications. 25. 2008. http://www-pub.iaea.org/MTCD/publications/PDF/trs464 web.pdf.

Accessed May 82016.

350 The Kewaunee County and the Manitowoc County Economic Development Corporations. "An Action Plan: Aligning the Region for Economic Success." Uploads. 4. July 2013. http://kcedc.org/wpcontent/uploads/2013/10/kewaunee-action-plan-report-SM.pdf. Accessed May 82016.

351 The Kewaunee County and the Manitowoc County Economic Development Corporations. "An Action Plan: Aligning the Region for Economic Success." Uploads. 5. July 2013. http://kcedc.org/wpcontent/uploads/2013/10/kewaunee-action-plan-report-SM.pdf. Accessed May 82016.

352 Southwest Region Planning Commission. "A Five-Year Strategic Plan for Economic Development in Citrus County, Florida." Files. 1. December 2013. http://www.swrpc.org/files/Citrus\%20County\%20EDC\%20\%20Five\%20Year\%20Strategic\%20Plan.pdf. Accessed May 82016.

353 Flavelle, Christopher. "What Happens After the Coal Plant Closes?" Bloomberg. 22 July 2015. http://www.bloomberg.com/view/articles/2015-07-22/what-happens-after-the-coal-plant-closes-.

Accessed May 112016.

${ }^{354}$ Electric Power Research Institute. "Decommissioning Handbook for Coal-Fired Power Plants." Vol. 3. Palo Alto. 2006. doi:1011220. 2-3.

355 Electric Power Research Institute. "Decommissioning Handbook for Coal-Fired Power Plants." Vol. 3. Palo Alto. 2006. doi:1011220.

356 Electric Power Research Institute. “Decommissioning Handbook for Coal-Fired Power Plants." Vol. 3. Palo Alto. 2006. doi:1011220.

357 McGeehan, P. "Plan to Close Nuclear Plant in Upstate New York Rattles Its Neighbors." The New York Times, November 17, 2015: A18. 2015.

358 Tribal Energy and Environmental Information. "Oil and Gas Decommissioning/Reclamation Impacts." Oil \& Gas. http://teeic.indianaffairs.gov/er/oilgas/impact/decom/index.htm. Accessed May 72016.

359 Tribal Energy and Environmental Information. "Oil and Gas Decommissioning/Reclamation Impacts." Oil \& Gas. http://teeic.indianaffairs.gov/er/oilgas/impact/decom/index.htm. Accessed May 72016.

360 Tribal Energy and Environmental Information. "Oil and Gas Decommissioning/Reclamation Impacts." Oil \& Gas. http://teeic.indianaffairs.gov/er/oilgas/impact/decom/index.htm. Accessed May 72016.

361 Tribal Energy and Environmental Information. "Oil and Gas Decommissioning/Reclamation Impacts." Oil \& Gas. http://teeic.indianaffairs.gov/er/oilgas/impact/decom/index.htm. Accessed May 72016.

362 Tribal Energy and Environmental Information. "Oil and Gas Decommissioning/Reclamation Impacts." Oil \& Gas. http://teeic.indianaffairs.gov/er/oilgas/impact/decom/index.htm. Accessed May 72016.

363 Tribal Energy and Environmental Information. "Oil and Gas Decommissioning/Reclamation Impacts." Oil \& Gas. http://teeic.indianaffairs.gov/er/oilgas/impact/decom/index.htm. Accessed May 72016.

364 Tribal Energy and Environmental Information. "Oil and Gas Decommissioning/Reclamation Impacts." Oil \& Gas. http://teeic.indianaffairs.gov/er/oilgas/impact/decom/index.htm. Accessed May 72016.

365 Tribal Energy and Environmental Information. "Oil and Gas Decommissioning/Reclamation Impacts." Oil \& Gas. http://teeic.indianaffairs.gov/er/oilgas/impact/decom/index.htm. Accessed May 72016. 